\title{
Progress on Active Analgesic Components and Mechanisms of Commonly Used Traditional Chinese Medicines: A Comprehensive Review
}

\author{
Ruizhou Wang ${ }^{1, \dagger}$, Lu Han ${ }^{1, \dagger}$, QiXia Gao ${ }^{2}$, Dan Chen ${ }^{3}$, Yun Wang ${ }^{4}$, Xia Zhang ${ }^{1}$, Xin $\mathrm{Yu}^{1}$, Yueming Zhang ${ }^{1}$, Zhiyong Li $^{2}$, \\ Changcai Bai ${ }^{1}$ \\ ${ }^{1}$ Key Laboratory of Hui Medicine Modernization, Ningxia Medical University Pharmacy College, Yinchuan, P. R. \\ China; ${ }^{2}$ College of Pharmacy, Minzu University of China, Beijing, P. R. China; ${ }^{3}$ General Hospital of Ningxia Medical \\ University, Yinchuan, P. R. China; ${ }^{4}$ Institute of Chinese Materia Medica, China academy of Chinese medical sciences, \\ Beijing, P. R. China.
}

Received, October 13, 2018; Revised, October 29, 2018; Accepted, November 16, 2018 ; Published, November 22, 2018.

\begin{abstract}
Many clinical diseases are accompanied by the symptoms of pain, and the degree of pain is closely related to the patients' suffering. Therefore, effectively relieving pain has become one of the vital concerns of clinical treatment and analgesic drug research. Non-opioid drugs are mainly used for the clinical treatment of mild to moderate pain, whereas opioid drugs are mainly used for treating moderate to severe pain. However, opioid drugs easily elicit adverse reactions, such as gastrointestinal discomfort, addiction, dependence, and so on. Traditional Chinese medicine and its active ingredients have unique advantages in the treatment of pain for quite a long time, and many analgesic drugs directly or indirectly were isolatiedfrom Chinese medicine or natural products, such as Liu Suan Yan Hu Suo Yi Su Pian and aspirin. With the development and modernization of research on herbal medicine more and more studies have been conducted on the active ingredients and mechanisms of traditional Chinese medicine analgesics. However, no review has been done on analgesic active components and their mechanisms. In this paper, 81 active components with clear chemical structure and definite analgesic effects in vivo and in vitro of traditional Chinese medicine and mechanisms of action reported in recent literatures are reviewed and summarized to provide reference for clinical analgesia and analgesics research.
\end{abstract}

\section{INTRODUCTION}

The International Association for the Study of Pain revised the definition of pain as follows: Pain is a mutually recognizable somatic experience that reflects a person's apprehension of threat to their bodily or existential integrity (1). Acute pain, which occurs as a response to a specific injury, has a biological importance and self-limiting character. By contrast, chronic pain is a disease state that may outlast the usual duration of recovery if accompanied with a disease or injury (2). Pain not only affects the quality of life and work efficiency, but also creates a huge financial burden, with a report showing that chronic pain alone costs as much as $\$ 635$ billion a year in the United States (3). Pharmacotherapy is often used for pain relief.

Non-opioid drugs are used in the treatment of mild to moderate pain, whereas non-opioid drugs are used for moderate to severe pain treatment (4). However, for most patients with pain, the analgesic effect of opioid drugs is limited, and their long-term use can lead to abuse, addiction, and overuse, with the latest data showing that about 16,000 overdose deaths associated with prescription opioids are reported each year, and the incidence of iatrogenic opioid dependence or abuse was $4.7 \%$ of those prescribed with opioids for pain (5-7). Traditional Chinese medicine (TCM) has been used in the treatment of pain for more than one thousand years, and scientists studying herbal medicines have found more than 800 kinds of TCM to be effective in relieving pain, while also creating several monomeric compounds to develop novel analgesic drugs. TCM has the advantages of good efficacy, is non-addictive, has less adverse reactions, and has an abundant supply, which attracted the attention of clinicians in the field of pain treatment.

Corresponding Authors: Zhiyong Li, College of Pharmacy, Minzu University of China, Beijing, P. R. China, E-mail, lizhiyong7899@sina.com; Changcai Bai, College of Pharmacy, Ningxia Medical University, Yinchuan, P. R. China, Email,changcaibai@163.com. ${ }^{\dagger}$ These authors contributed to the paper equally. 
With the increasingly progress of medicine and technology and the better understanding of natural medicine, the interest and acceptance of TCM have been increasing, and its role in health has been widely recognized in the world (8-10). In recent years, the exploration of TCM in analgesia has become one of the hotspots of modern Chinese medicine research.

In modern pharmacological study, plenty of compounds with significant analgesic activity were isolated from TCM, including alkaloids, flavonoids, terpenoids, aromatic compounds, coumarins, aliphaticnatural products, and lignans. In this paper, the analgesic effect and mechanism of these compounds are reviewed, to provide a reference for the development and utilization of TCM for analgesia.

\section{ANALGESICS BASED ON THE COMPOUNDS' PHYTOCHEMISTRY}

Many classic analgesics, such as morphine, codeine, and aspirin are isolated from natural products. Therefore, the study on the analgesic effect and mechanisms of active components and the discoveries of new analgesic drugs from plants provide grounds for innovative research on analgesic drugs.

Upon a literature survey we identified a total of 81 compounds with significant analgesic activities, including 40 alkaloids, 15 flavonoids, 10 terpenoids, 5 aromatic compounds, 8 coumarins, 2 aliphaticnatural products, and 1 lignan. A compound may exist in a variety of herbal medicine, and we have summarized all its sources (Table 1). The structures of these compounds and their analgesic activities are shown in Figure. 1

\section{Alkaloids}

Alkaloids are a class of nitrogen heterocyclic compounds containing negative oxidized nitrogen atoms in biological organisms and are the most important analgesic compounds. Isoquinoline alkaloids (1-9), indole alkaloids (10-20), terpene alkaloids (21-29), pyridine and piperidine alkaloids (30-33), and amide alkaloids (34-40) were shown to have significant analgesic activity.

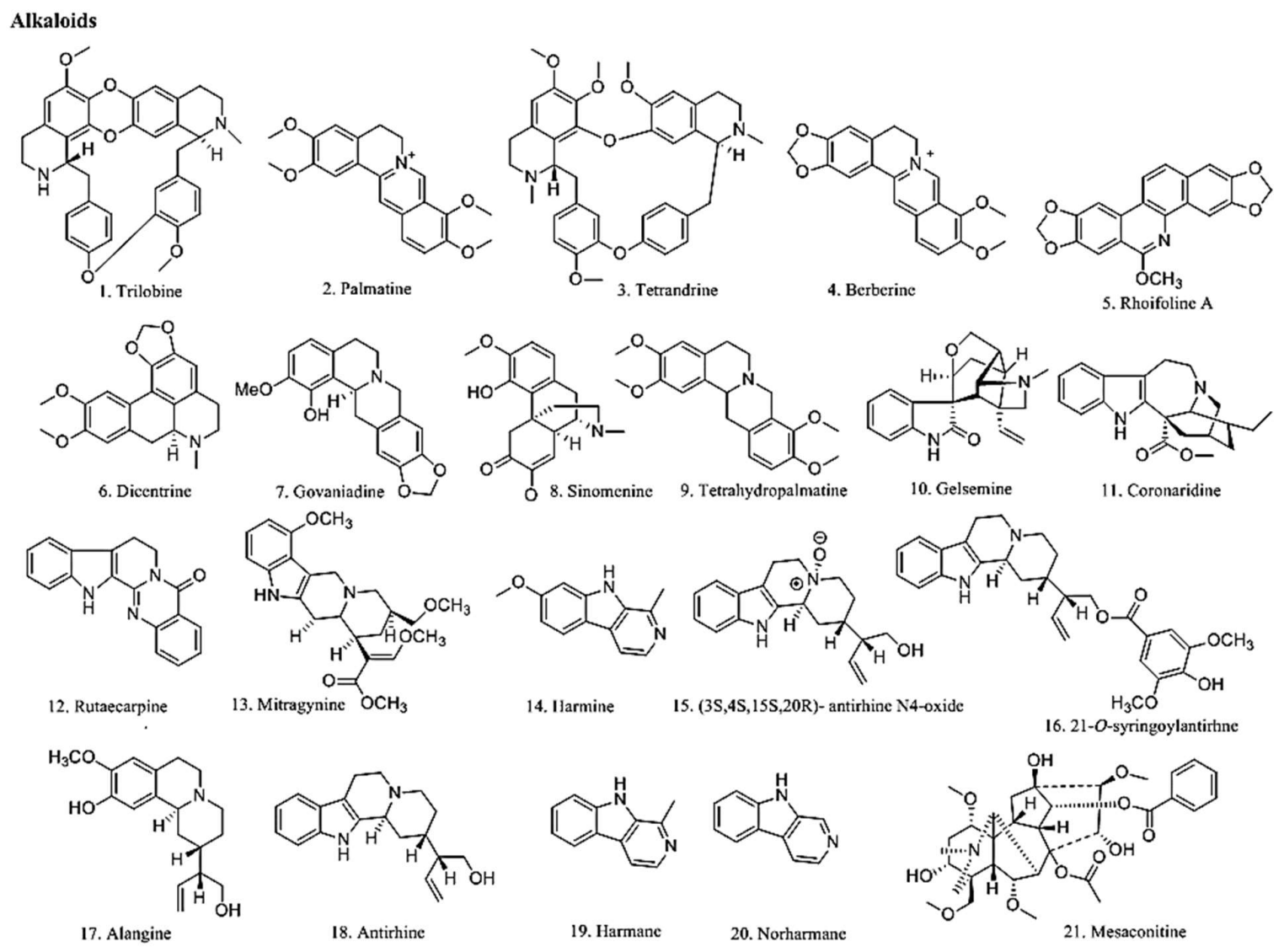

Figure 1 continued... 


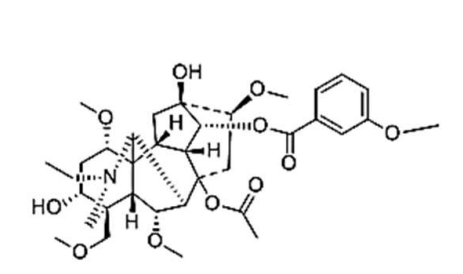

22. Yunaconitine

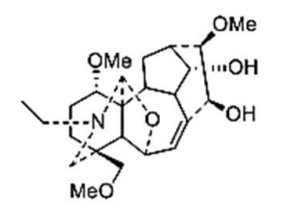

26. Guiwuline

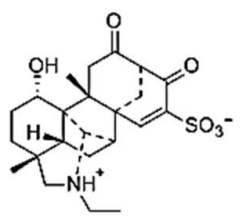

29. Aconicarmisulfonine A

30. Oxymatrine
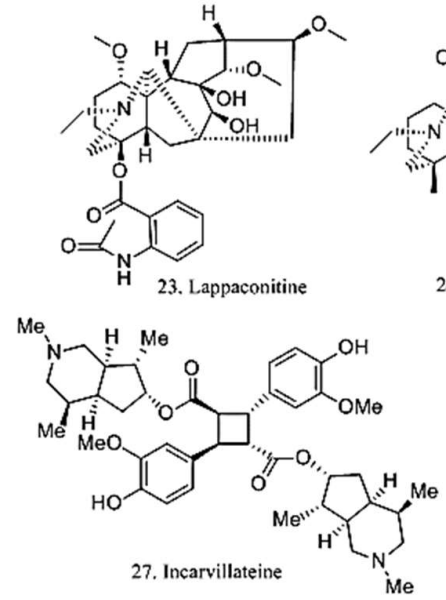

24. Bullatine A

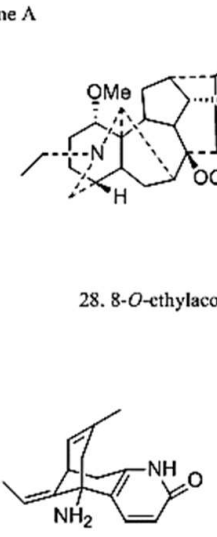

32. Huperzine A
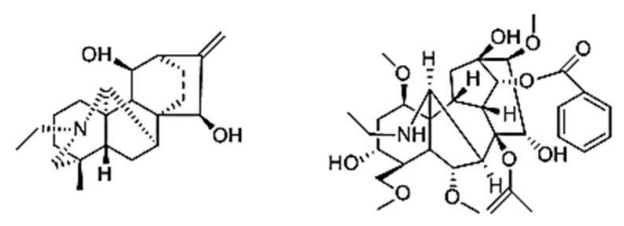

25. Aconitine<smiles>CC(=O)CCCCCCCCCCCCC[C@@H]1CC[C@@H](O)[C@H](C)N1</smiles>

31. (-)-Spectaline

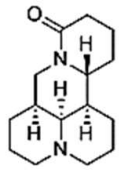

33. Matrine
(1)

34. Capsaicin

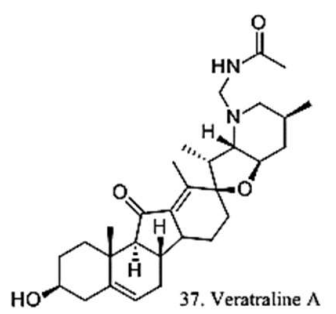

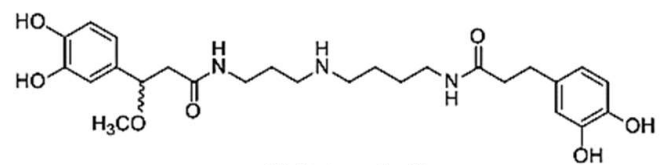

35. Scotanamine B

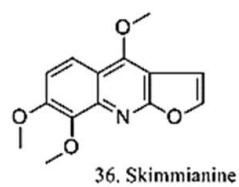

36. Skimmianine

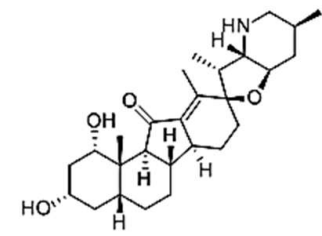

39. Veratraline C

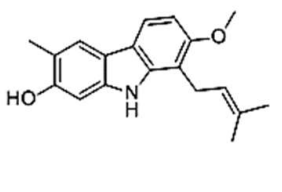

40. Isomurrayafoline $B$

\section{Flavonoids}

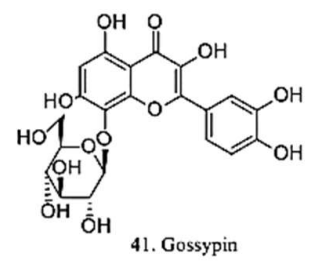

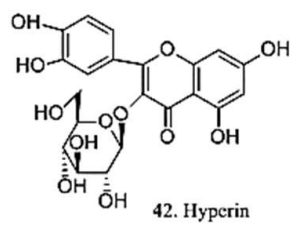<smiles>O=c1cc(-c2ccccc2)oc2cc(O)cc(O)c12</smiles>

43. Chrysin<smiles>COc1ccc(-c2cc(=O)c3c(O)cc(O)cc3o2)cc1</smiles>

48. Quercetin

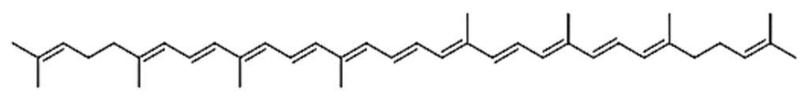

44. Lycopene<smiles>COc1ccc(-c2cc(=O)c3c(O)c(OC)c(O)cc3o2)cc1OC</smiles>

45. Eupatilin

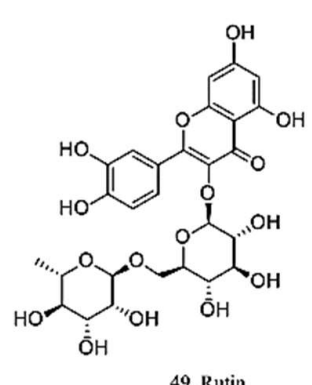

Figure 1 continued... 
<smiles>O=c1c(O)c(-c2ccc(O)cc2)oc2cc(O)cc(O)c12</smiles>

50. Kaempferol<smiles>COc1cc(/C=C/C(=O)CC(=O)c2ccc(O)c(OC)c2)ccc1O</smiles>

53. Curcumin

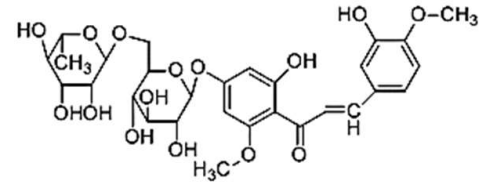

51. Hesperidin methyl chalcone

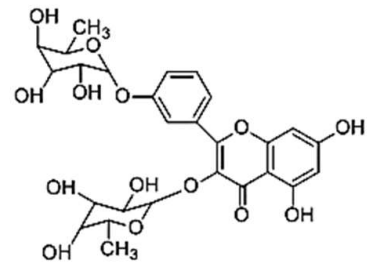

Terpenes

54. Kempferol-3,4' -di-O- a -L-rhamnopyranoside

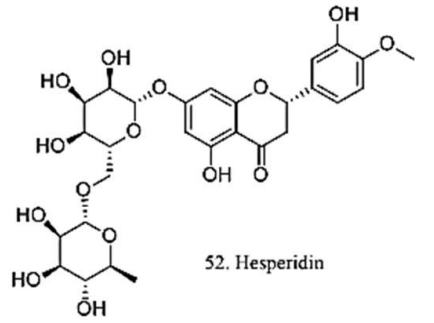

SS. Myricitrin

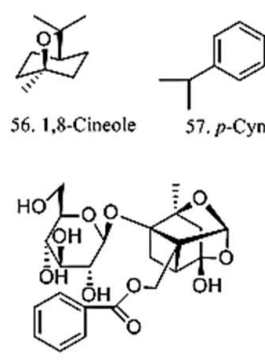

59. Paeoniflorin

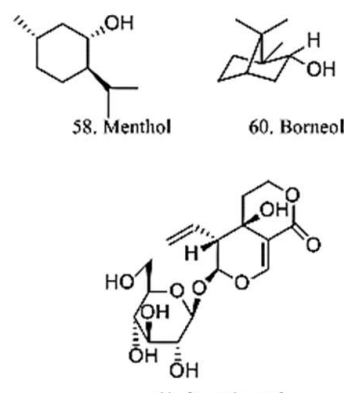

61. Swertiamarin
$\mathrm{CH}_{\mathrm{CH}_{3}}$ 63. Geraniol

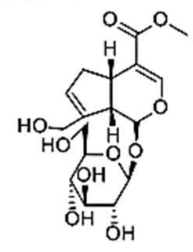

62. Geniposide

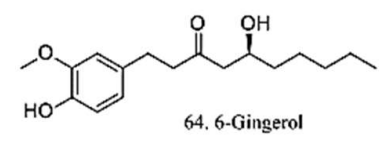

${ }_{\mathrm{OH}}^{\mathrm{H}_{3} \mathrm{C}}$

65. Myrtenol

\section{Aromatic compounds}
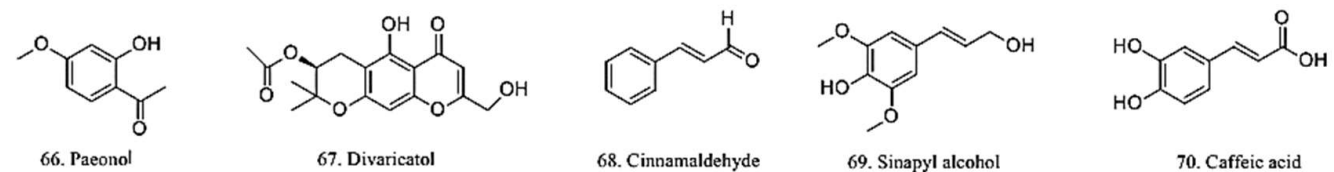

\section{Coumarins}
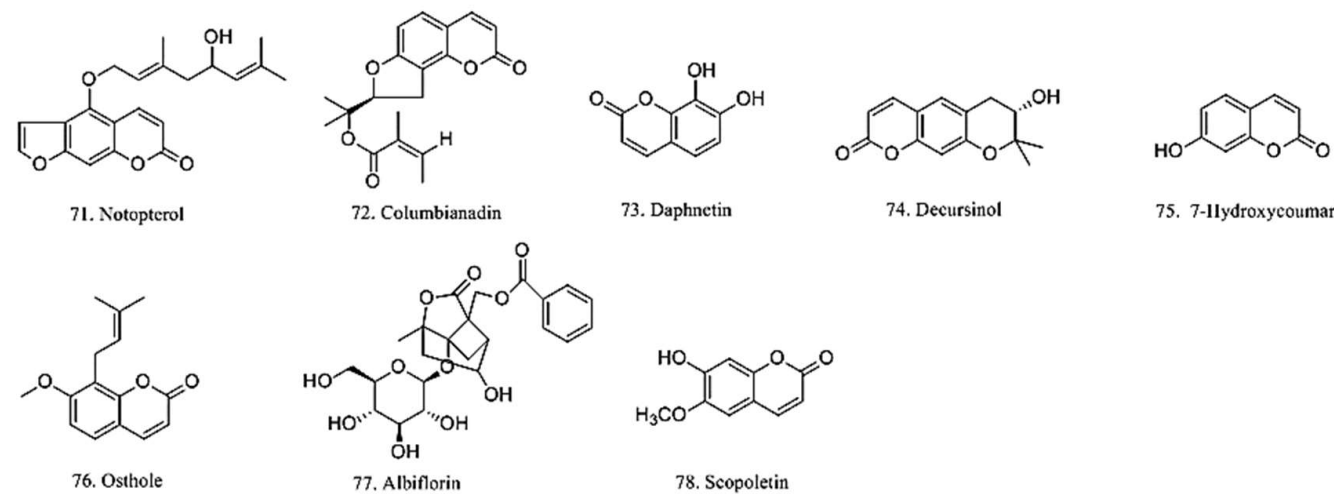

73. Daphnetin

74. Decursinol

75. 7-11ydroxycoumarin

77. Albiflorin

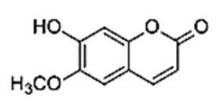

78. Scopoletin

Aliphaticnatural products

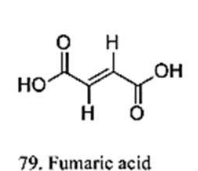

79. Fumaric acid

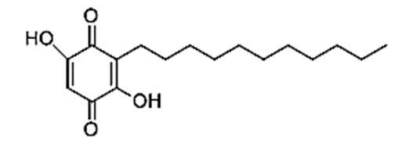

80. Embelin

\section{Figure 1 continued...}




\section{Lignans}

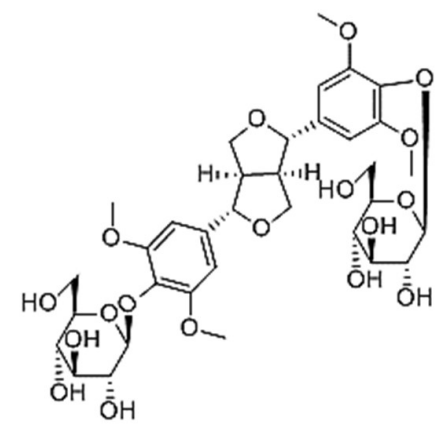

81. Liriodendrin

Figure 1 Structures of analgesic compounds in TCM

\section{Flavonoids}

Flavonoids are formed in plants from the aromatic amino acids phenylalanine and malonate. The basic structure of flavonoids is the flavonoid nucleus, which consists of 15 carbon atoms labeled as the three rings of $\mathrm{A}, \mathrm{B}$, and $\mathrm{C}\left(\mathrm{C}_{6}-\mathrm{C}_{3}-\mathrm{C}_{6}\right)$. The various classes of flavonoids differ in the level of oxidation and the pattern of substitution of the $\mathrm{C}$ ring, whereas individual compounds within a class differ in the pattern of substitution of the A and B rings (11). Flavonoids (41-55) in TCM play an important role in analgesia, and have high application value and prospect.

\section{Terpenoids}

Terpenoids are the most structurally diverse class of plant natural products biosynthesized from isoprene units with a general formula of $\left(\mathrm{C}_{5} \mathrm{H}_{8}\right) \mathrm{n}$. Terpenecompounds are the main components of volatile oils, also known as essential oils, and have wide physiological activities, such as expectorant, relieving cough, transpiration and analgesia. A total of 10 terpenoids (56-65) have been reported to show analgesic activities.

\section{Aromatic compounds}

Aromatic compounds are often used in cosmetics, consumer goods, and in the medical field. These compounds are widely found in Chinese herbal medicines, such as Paconia lactiflora, Saposhnikouia diuaricata, Cinnamomum japonicum, and so on, and some aromatic compounds (66-70) in TCM show good analgesic effect.

\section{Coumarins}

Coumarin is one of the most important natural organic compounds in nature products. Moreover, it has many biological activities, such as anti-HIV, anti-cancer, antihypertensive, anti-arrhythmia, antiosteoporosis, anti-asthmatic, antibacterial, and analgesic effects. Experiments showed that coumarin compounds, such as notopterol, columbianadin, daphnetin, decursinol, 7hydroxycoumarin, and osthole (71-78) have good analgesic effects.

\begin{abstract}
Aliphaticnatural products
Aliphatic naturalproducts are an important class of compounds in the organic chemistry industry. They can be used in spices and in the preparation of some drugs according to their properties. Two aliphatic natural products, such as fumaric acid (79) isolated from Corydalis yanhusuo and embelin (80) isolated from Embelia oblongifolia, Ardisia crenata, and Embelia ribes, also showed good analgesic activities.

\section{Lignans \\ Lignan is a class of secondary metabolite that is usually in the form of a glycoside and consists of two phenyl-propanoid molecules connected by 8 - 8 'carbon atoms. Liriodendrin (81) was the only lignan reported to have significant analgesic activity.}

\section{ANALGESIC ACTIVITIES}

The analgesic activities of monomeric compounds isolated from TCM in vivo were studied. Experimental animal models of acute and chronic pains are the two major types of pain model for 
studying analgesic effects. Studies of acute pain model include chemical stimuli, such as acetic acid, capsaicin, glutamate, acetylcholine, and $p$ benzoquinone-writhing test, formalin test, and physical stimulation, such as hot or cold-plate test, tail-flick test, electrical stimulation test, RandallSelitto test, tail immersion test, Hargreaves test, and the mechanical von Frey test. Studies have shown that chronic pain are induced by chronic constriction injury (CCI), spared nerve injury(SNI), spinal cord injury (SCI), and partial sciatic nerve ligation (PSNL). Other types include paclitaxel-induced neuropathic pain, diabetic neuropathic pain, complete Freund's adjuvant (CFA)-induced pain, LPS-induced inflammation pain, and cancer pain. The experimental studies on the analgesia of active compounds are summarized in Table 2.

\section{ANALGESIC MECHANISM}

Modern studies have shown that compounds isolated from TCM play a key role in the regulation of painrelated signaling pathways (10). The mechanisms of analgesia could be roughly divided into the central nervous system to exert a central analgesic effect and through the peripheral nervous system to relieve pain by reducing the secretion of analgesic substance, alleviating the accumulation of local analgesic substances, increasing the release of peripheral endogenous analgesic matter, and regulating c-Fos genes. Moreover, some compounds relieve pain by inhibiting the process of inflammation.

\section{Activate opiate receptors and increase opioid peptide levels}

Opioid peptides ( $\beta$-endorphin, encephalin, and dynorphin) are widely distributed in the hypothalamus, brain, and spinal cord. They bind to opioid receptors, $\mu$ (mu or MOP) receptor, $\delta$ (delta or DOP) receptor, and $\kappa$ (kappa or KOP) receptor, and reduce the release of nociceptive substances and produce strong analgesic effects.

$p$-Cymene, an aromatic monocyclic monoterpene, could found in the volatile oils of more than 100 plants and naturally occurs in over 200 foods (12). The analgesic effects of $p$-cymene in tail-flick test was antagonized by naloxone (nonselective antagonist of opioid receptors), naltrindole ( $\delta$-opioid receptor antagonist), nor-BNI ( $\kappa$-opioid receptor antagonist), and CTOP ( $\mu$-opioid receptor antagonist). These suggested that the antihyperalgesia of $p$-cymene maybe related to the opioid system (13). Naloxone and nor-NBI could antagonize the antinociceptive effect of menthol, which is a natural cooling product of peppermint and is widely used as an analgesic agent for pain conditions, such as sports injuries and arthritis, but CTOP, 7-benzylidenenal-trexone ( $\delta_{1}$ antagonist) and naltriben $\left(\delta_{2}\right.$ antagonist $)$ could not. These suggest that menthol mediates analgesic properties through the selective activation of к opioid receptors $(14,15)$.

Capsaicin, the main ingredient in hot pepper, has an analgesic action in humans. Capsaicin significantly could increase the proopiomelanocortin mRNA levels in the arcuate nucleus of rats, suggesting that the analgesic effect of capsaicin couldbe associated with the increased activities of cerebral opioid systems (16). Quercetin which could be widely found in flowers, leaves, and fruits of plants and found in more than 100 Chinese herbs, could relieve cancer pain and diabetic neuropathic pain via the opioid-dependent analgesic pathways (17). Curcumin, a yellow pigment extracted from zingiberaceous plants, has a wide range of therapeutic effects, such as anti-inflammatory, antibacterial, anti-viral, anti-fungal, anti-tumor, antispasmodic, and hepatoprotective effects. Curcumin could relieve diabetic peripheral neuropathic pain, and its mechanism could be related to the opioid system (18).

The analgesic effect of scotanamine B, an amide alkaloid from Scopolia tangutica, was recorded using the tail-flick assay and was reversed by naloxone. Scotanamine B displayed agonist activity at the $\mu$ receptor with an $\mathrm{EC}_{50}$ value of $7.3 \mathrm{Mm}$. Naloxone could also antagonize analgesic effects of govaniadine in the hot-plate test and the inhibition of paeoniflorin on bee venom-induced persistent spontaneous nociception (19-21). At the same time, naltrexone partially blocked analgesic effect in thehot-plate test of hesperidin (hesperetin-7rhamnoglucoside), which is the main flavonoid in sweet oranges and lemons with anti-inflammatory, sedative, and analgesic effects. Although the analgesic effect of hesperidin is mediated through opioid mechanisms, it does not directly bind to and activate $\mu$ opioid receptors and has no effect on the inward GIRK1/2 currents $(22,23)$.

Bullatine A, a $\mathrm{C}_{20}$-diterpenoid alkaloid, is one of the main active components of Aconitum brachypodum. Bullatine A could reduce pain hypersensitivity in the rat model of neuropathic pain, inflammatory pain, diabetic neuropathic pain, or bone cancer pain but could not block the acute nociceptive response effectively under normal conditions. This alkaloid specifically stimulates the expression of dynorphin A in spinal microglia in 
vivo and in the cultured primary microglia in vitro. The stimulatory effect of bullatine A was completely inhibited by the microglial inhibitor minocycline, and its spinal anti-allodynic effects were completely blocked by intrathecal injection of minocycline, the specific dynorphin A antiserum, and the selective $K-$ opioid receptor antagonist. Thus, the expression of spinal microglial dynorphin A could be stimulated to mediate bullatine $\mathrm{A}$ anti-nociception under the pain hypersensitivity conditions (24).

\section{Affect cholinergic nerve system}

The two types of cholinergic receptors are muscarinic $(\mathrm{M})$ receptors and nicotinic $(\mathrm{N})$ receptors. $\mathrm{M}$ cholinergic receptors are divided into five subtypes, $M_{1}-M_{5}$ and $M_{2} / M_{4}$ receptors are involved in mediating muscarinic analgesia. In addition, the agonists of nicotinic and muscarinic acetylcholine receptors are being evaluated as candidate analgesics and may represent a new therapeutic strategy for the treatment of pain (25).

Matrine, along with lupinine, sparteine, and cytosine, is a typical lupine alkaloid that could be found in many leguminous plants, especially Sophoras pecies. Hot-plate test results showed that muscarinic receptor antagonists atropine $(5 \mathrm{mg} / \mathrm{kg}$ i.p.) and pirenzepine $(0.1 \mu \mathrm{g} / \mathrm{mouse}$ i.c.v. $)$ and acetylcholine depletor hemicholinium-3 (1 $\mu \mathrm{g} /$ mouse i.c.v.) can attenuate the analgesic effect produced by $(+)$-matrine $(10 \mathrm{mg} / \mathrm{kg} \mathrm{s.c.})$, whereas the opioid receptor antagonist naloxone $(2 \mathrm{mg} / \mathrm{kg}$ i.p.), dopamine $\mathrm{D}_{2}$ receptor agonist (-)-quinpirole $(0.1 \mathrm{mg} / \mathrm{kg}$ i.p. $)$, or catecholamine depletor reserpine (2.5 mg/kg i.p.) cannot. Meanwhile, radioligand binding assay results showed that $(+)$-matrine exhibits no affinity for $\mu$, $\kappa$, and $\delta$-opioid receptors. Hence, (+)-matrine exerted its analgesic effect by increasing cholinergic activation in the central nervous system rather than by acting on opioid receptors directly (26).

Previous studies suggested that huperzine A, a natural plant alkaloid isolated from Huperzia serrata, is a potent analgesic with few side effects. In 2015, results of the conditioned place preference behavioral assay showed that huperzine A could attenuate mechanical allodynia induced by peripheral nerve injury, and this effect was blocked by the M-receptor antagonist atropine. Furthermore, ambenonium chloride, a competitive inhibitor of acetylcholinesterase, also increased paw-withdrawal threshold, but failed to induce place preference in conditioned place preference. Therefore, acetylcholinesterase in both the peripheral and central nervous systems were involved in the regulation of mechanical allodynia by huperzine $\mathrm{A}$ (27).

\section{Affect central catecholaminergic system}

Central catecholaminergic systems mainly include norepinephrine (NE), adrenaline (Adr), dopamine (DA), and so on, which are not only neurotransmitters, but also can cause pain directly and participate in pain and analgesia. In the peripheral nervous system, they stimulate sensory nerve endings and cause pain as pronociceptives through second messenger action on the local and paracrine signaling. In the central nervous system, they have inhibitory and excitatory effects on the neurons. However, the inhibition effect is the main factor resulted in pain threshold is raised.

Mesaconitine is a principal alkaloid from Aconitum carmichaeli and Aconitum kusnezoffii. The analgesic effect of mesaconitine was decreased by $\alpha$-methyl-p-tyrosine, $\quad 6$-hydroxydopamine, diethyldithiocarbamate, disulfiram, and reserpine, and was increased by methamphetamine and norepinephrine. In addition, mesaconitine promoted the $\alpha$-methyl-p-tyrosine-induced decrease in norepinephrine levels in hippocampus, medulla oblongata plus pons, and spinal cord. Thus, the analgesic activity mediated by mesaconitine is closely related to responses involving thecentral catecholaminergic system, in particular, the noradrenergic system (28). Mesaconitine increases the excitabilities in rat hippocampal pyramidal cells by enhancing the extraneuronal noradrenaline level through inhibition of noradrenaline uptake (29). Results of tail-immersion and hot-plate tests showed that pretreatment with 6-hydroxydopamine $(50 \mu \mathrm{g}$, i.c.v. or $20 \mu \mathrm{g}$, i.t.) or 5,7-dihydroxytryptamine ( 80 $\mu \mathrm{g}$, i.c.v. or $20 \mu \mathrm{g}$, i.t.) couldclearly reduce lappaconitine, an important bisnorditerpenoid alkaloid. Meanwhile, the analgesic effect of lappaconitine (i.c.v.) could be reduced by pretreatment with $\beta$-adrenergic antagonist timolol. The i.t. administration of lappaconitine induces a strong analgesic effect, which can be reduced by pretreatment with $\alpha$-adrenergic antagonist phenoxybenzamine. These data suggested that central norepinephrine influences the analgesic effect of lappaconitine and these pathways are mediated by the expression of $\beta$-adrenoceptors and $\alpha$-adrenoceptors in the spinal cord (30).

Paeoniflorin and albiflorin have obvious analgesic effect in tail-pressure test in diabetic mice shown by measuring the struggling behavior as an 
index of threshold. Yohimbine, an $\alpha_{2}$-adrenoceptor antagonist, could abolish completely the antinociceptive effect of paeoniflorin, and albiflorin increased noradrenaline release and activated $\alpha_{2}$ adrenoceptor to modulate spinal nociceptive transmission in diabetic neuropathy (31).

Moreover, levo-tetrahydropalmatine, a tetrahydroprotoberberine isoquinoline alkaloid, is a primary active constituent from the genus Corydalis. Levo-tetrahydropalmatine does not influence motor function but exerts antihyperalgesic effects that can be abolished by a dopamine $\mathrm{D}_{1}$ receptor antagonist SCH23390 (0.02 mg/kg). Thus, this alkaloid improves mechanical hyperalgesia by enhancing dopaminergic transmission mediated by dopamine $\mathrm{D}_{1}$ receptor (32).

\section{Increase the content of 5-hydroxytryptamine (5- HT)}

5-HT is one of the main neurotransmitters involved in the descending control of pain or emotion in the central nervous system and it works by binding with specific 5-HT receptors (33). The analgesic effect of lappaconitine was reduced by pretreatment with ketanserin, a 5- $\mathrm{HT}_{2}$ antagonist, and mianserin, a 5$\mathrm{HT}_{1}$ antagonist. Thus, the analgesic mechanism of lappaconitine may be related to the $5-\mathrm{HT}_{2}$ receptor in the brain and the 5-HT $\mathrm{HT}_{1}$ receptor in the spinal cord (30).

Acacetin (5, 7-dihydroxy-4-methoxyflavone), a bioflavonoid compound, was reported to possess antiperoxidative, anti-inflammatory, and antiplasmodial activities. WAY100635, a selective $5-\mathrm{HT}_{1 \mathrm{~A}}$ receptor antagonist, partially reduced the antinociceptive response of acacetin in the acetic acid-induced writhing test. $5-\mathrm{HT}_{1 \mathrm{~A}}$ seems to be involved in the mechanism of acacetin analgesia (34). Besides, quercetin also could alleviate arthritis pain by mediating by serotonin $5-\mathrm{HT}_{1 \mathrm{~A}}$ receptors (35).

\section{Inhibite neurotransmitter $\boldsymbol{\gamma}$-aminobutyric acid (GABA)}

GABA, the major inhibitory neurotransmitter in the central nervous system, has three types of receptors, namely, $\mathrm{GABA}_{\mathrm{A}}, \mathrm{GABA}_{\mathrm{B}}$, and $\mathrm{GABA}_{\mathrm{C}}$. The dysfunction or deficiency of GABAergic system is associated with epilepsy, pain, and anxiety (36). Recent studies have demonstrated in a rat model of neuropathic pain that the $\mathrm{GABA}_{\mathrm{A}}$ receptor antagonist bicuculine dose-dependently blocked the antinociceptive effects of sinomenine, a main bioactive ingredient in Sinomenium acutum, which is well known to have anti-rheumatism and immunomodulatory effects (37).

Chrysin (5, 7-dihydroxyflavone) is a natural flavone commonly found in many plants with a wide range of biological activities, including antioxidant, anti-allergic, anxiolytic, and vasorelaxant activities. Tail-immersion tests also show that chrysin has significant analgesic activity, which can be significantly and dose-dependently suppressed by pretreatment with flumazenil, a specific antagonist for benzodiazepine sites associated with $\mathrm{GABA}_{\mathrm{A}}$ receptors and with bicuculline, a $\mathrm{GABA}_{\mathrm{A}}$ receptor antagonist. These results indicate that the analgesic effect of chrysin is acted on $\mathrm{GABA}_{\mathrm{A}}$ receptors (38).

Another study showed that the oxymatrinecarbenoxolone sodium inclusion compound had obvious analgesic effect in the hot-plate test, tail immersion test, acetic acid induced abdominal constriction, and formalin-induced pain, and simultaneously increased the $\mathrm{GABA}_{\mathrm{A}} \alpha_{1}$ receptor expression in the spinal cord, the cerebral cortex, and the hippocampal region of mice (39).

\section{Regulate ion channels}

Calcium ion $\left(\mathrm{Ca}^{2+}\right)$ overload and $\mathrm{Na}^{+}$currents are instrumental in the etiology of pain and neuropathy. $\mathrm{Ca}^{2+}$ enters into cells by different ways including cation channels, chemical channels, and voltage gated calcium channels. Furthermore, the two types of neuronal voltage-gated $\mathrm{Na}^{+}$channels are tetrodotoxin-sensitive and tetrodotoxin-resistant. Studies show that $\mathrm{Na}^{+}$channels have demonstrated a great involvement in inflammatory pain and in pain sensation $(36,40)$.

Rhoifoline A, a benzodihydropyridine alkaloid obtained from Zanthoxylum nitidum, could inhibit the chemical nociception induced by acetic acid and formalin, the thermal nociception in the hot-plate test and tail-flick test. The analgesic effect of rhoifoline A was significantly antagonized by nimodipine, a blocker of L-type $\mathrm{Ca}^{2+}$ channels in the hot-plate test. Therefore, the analgesic mechanism of rhoifoline A possibly involved L-type $\mathrm{Ca}^{2+}$ channels (41).

Hyperin, an important natural product, has antiinflammatory, antispasmodic, diuretic, antitussive, antihypertensive, cholesterol-lowering, central analgesic, cardio-cerebral vascular protection, and other physiological activities. Low or high-calcium can significantly strengthen or antagonize the inhibitory effect of hyperin on nerve dischargeinduced histamine and potassium chloride. $\mathrm{A}_{23187}$, which promotes the influx of $\mathrm{Ca}^{2+}$, could antagonize 
the effect of hyperin. These findings suggest that the analgesia of hyperin is closely related to the reduction of $\mathrm{Ca}^{2+}$ influx of sensory nerve endings (42). Sinomenine suppressed formalin-induced pain behavior only in the first phase, but not the second phase. Sinomenine also significantly reduced voltage gated sodium currents in a dose-dependent manner $\left(\mathrm{IC}_{50}=2.3 \pm 0.2 \mathrm{mM}\right)$, suggesting that sinomenine has a peripheral analgesic effect (43).

Oxymatrine, a natural quinolizidine alkaloid, is the main basic constituent derived from the root of Sophora flavescens and the seeds of Sophora alopecuroides. The inhibition of voltage-activated $\mathrm{K}^{+}$channel plays an important role in the analgesic effect of oxymatrine. Meanwhile, oxymatrine could decrease $\mathrm{Ca}_{2}{ }^{+}$in cultured dorsal root ganalia neurons, decrease protein expression levels of Cav2.2 in the brain tissue, and increase protein expression levels of Cav2.2 in dorsal root ganalia tissues $(44,45)$.

Tetrandrine is a bisbenzylisoquinoline alkaloid, which mainly exists in Menispermaceae. Previous studies have shown that it possessed antiarrhythmic, antihypertensive, cardioprotective, antitumorigenic, anti-inflammatory, and analgesic effects (47). The analgesic effect of tetrandrine could be significantly antagonized by $\mathrm{CaCl}_{2}$ through intracerebroventricular or intraperitoneal administration. On the contrary, EGTA could enhance the analgesic effect of tetrandrine, suggesting that the analgesic mechanism of tetrandrine might be related to calcium antagonists (47).

A study showed that menthol decreased inflammatory pain induced by CFA in a dosedependent manner, and formalin-induced spontaneous nocifensive behavior. Menthol blocked voltage-gated sodium channels and voltage-gated calcium channels in a voltage-, state-, and usedependent manner. Furthermore, repetitive firing, action potential amplitude, and neuronal excitability were decreased by menthol. At the same time, spontaneous synaptic transmission of cultured superficial dorsal horn neurons was blocked by menthol. Menthol has central analgesic effect on inflammatory pain, which may be related to the blocking of voltage-gated $\mathrm{Na}^{+} / \mathrm{Ca}^{2+}(48)$.

Studies showed that the natural coumarin osthole has a variety of pharmacological effects, such as anti-tumor, anti-convulsant, antiinflammatory, osteogenic, anti-hepatitis, neuroprotective, and analgesic activities, and has a obvious effect on nucleus pulposus-evoked pain by inhibiting overexpression of acid-sensitive ion channel 3 in rat dorsal root ganglion and inhibiting the activation of extracellular signal-regulated kinase in rats $(49,50)$

\section{Inhibit of glutamate receptor}

Glutamate receptors, which are the major excitatory neurotransmitter receptors in the brain and play an important role in analgesia, has different subtypes of glutamate receptors each of which can be divided into several subtypes, such as NMDA receptors (GluN1 to GluN3), AMPA receptors (GluA1 to GluA4), kainate receptors (GluK1 to GluK5), and mGlu receptors (mGluR1 to mGluR8). Almost all types of glutamate receptors are involved in the formation of hyperalgesia (51).

Gelsemine is the main active ingredient of Gelsemium elegans and shows significant analgesic activity in various chronic pains models, such as formalin-induced tonic pain, spinal nerve ligationinduced painful neuropathy, and bone cancerinduced mechanical allodynia. Strychnine, the glycine receptor (GlyR) antagonist, could relieve the analgesic effect of gelsemine with an apparent $\mathrm{ID}_{50}$ value of $3.8 \mu \mathrm{g}$ (52). The analgesic action of gelsemine in neuropathic pain was prevented by gene ablation of the GlyR $\alpha 3$ subunitnearly and completely, but not GlyR $\alpha 1$, indicating that gelsemine generates analgesic effect via spinal $\alpha 3$ glycine receptors. Gelsemine directly regulates recombinant and native glycine receptors and play conformational specificity and subunit selectivity effects (53).

Paeonol, a micromolecular phenolic compound, has been proven to have a variety of pharmacological and physiological effects, such as sedation, hypnosis, antipyresis, antioxidation, antiinflammation, antibacteria, immunoregulation, antitumor, and analgesia (54). Paeonol could relieve inflammatory pain and reverse the upregulated levels of NR2B, CaMKII $\alpha$, GluR1, p-GluR1-Ser831, ERK/CREB, and mTOR pathway proteins in anterior cingulate cortex in CFA mice, but has no effect on NR2A, p-GluR1-Ser845, and $\mathrm{GABA}_{\mathrm{A}}-\alpha_{2}$ (55).

Oxymatrine could lower the threshold of CCI mice in mechanical allodynia and thermal hyperalgesia test. At the same time, the mean IOD of NR2B in the dorsal horn and expression levels of NR2B, p-ERK, and p-CREB protein in the chronic neuropathic pain model were decreased by oxymatrine. Thus, the regulation of NMDA NR2B receptor-ERK/CREB signaling may be the targets for the antinociceptive effects of oxymatrine (56). 
In addition, recent reports confirmed that paeoniflorin exerted central analgesic effect through adenosine $A_{1}$ receptor by inhibiting colorectal distention-evoked glutamate release and the NMDA receptor dependent extracellular signal-regulated protein kinase (p-ERK) signaling in rats with neonatal maternal separation-induced visceral hyperalgesia (57).

\section{Affect transient receptor potential (TRP)}

Transient Receptor Potential (TRP) family of ion channels expressed on nociceptors, the TRP superfamily contains 28 channels with 7 different subgroups, and TRPA1, TRPV1 and TRPV4 have been associated with pain transmission of sensory neurons, including DRG (40).

Hyperpolarization-activated inward currents are blocked by capsaicin via TRPV1 in the rat dorsal root ganglion neurons. The analgesic effects of capsaicin reportedly cause the densensitization of nociceptive neurons owing to depletion of painrelated substances (58). Apart from this, studies have shown that the aporphinic alkaloid dicentrine could attenuate spontaneous nociception and mechanical cold hypersensitivity in inflammation pain model probably via a TRPA1-dependent pathway (59).

Borneol, also known as bingpian or longnao in Chinese, is a bicyclic monoterpene compound and a time-honored herb from Cinnamomum tree in TCM, has been used for more than 2,000 years in clinical applications. The TRPM8 channel was identified as a molecular target for borneol in the pain mouse models induced by CFA, capsaicin, and formalin, showing that topical borneol-induced analgesia was almost exclusively mediated by TRPM8 (60).

1, 8-cineole, a terpene oxide and a TRPM8 agonist, is the main component of most eucalyptus oil (75\%), rosemary (40\%), and many other essential oils. The sensory irritation tests in vivo showed that 1, 8-cineole conferred an analgesic effect due to its inhibition of TRPA1 (61).

Additionally, L-menthol could effectively alleviate pain behavior in many pain models, such as chemical stimuli (capsaicin, acrolein, acetic acid), noxious heat and inflammation pain induced by CFA. The genetic deletion of TRPM8 completely abolished the analgesia caused by L-menthol in all these models, while other analgesics (acetaminophen) remained effective. When mice were treated with AMG2850, a selective TRPM8 inhibitor, the analgesia effect of L-menthol disappeared. Consequently, TRPM8 is the principal mediator of menthol-induced analgesia of acute and inflammatory pain (14). TRPV1 receptor was reported to be involved in the analgesic effect of hesperidin and curcuminoid in inflammatory pain model $(62,63)$.

\section{Influence adenosine system}

The adenosine receptor system is promising for pain treatment. Adenosine receptors are widely distributed not only in the spinal cord and brain areas involved in pain transmission but also in peripheral sensory afferents or adjacent cells.

Incarvillateine mainly exists in Incarvillea sinensis, a traditional Chinese medicine used to treat rheumatism and bruises and is very effective for pain and inflammation. Incarvillateine dose-dependently attenuated acetic acid-induced writhing, thermal hyperalgesia of CFA inflammatory pain, and mechanical allodynia of SNI or paclitaxel-induced neuropathic pain. Incarvillateine-induced analgesia was attenuated by theophylline (nonselective adenosine antagonist), 1, 3-dipropyl-8cyclopentylxanthine ( $\mathrm{A}_{1}$ agonist), and 3, 7-dimethyl1-propargylxanthine ( $A_{2}$ agonist). These findings showed that the analgesic mechanism of incarvillateine may be related to the adenosine system in inflammatory and neuropathic pain models (64).

Levo-tetrahydropalmatine has remarkable analgesic effect and as an analgesic has been used clinically for more than 40 years. Treatment with levo-tetrahydropalmatine suppressed the increase of mechanical allodynia and spinal phosphorylation of the NMDA receptor NR1 subunit expression in CCI mice model. Intrathecal treatment with levotetrahydropalmatine combined with the Sig-1R antagonist, BD1047, synergistically blocked mechanical allodynia. Intrathecal pretreatment with naloxone, a non-selective opioid receptor antagonist, did not affect levo-tetrahydropalmatine. These results show that analgesic effect of levotetrahydropalmatine modulates spinal Sig-1R activation (65).

Paeoniflorin significantly attenuates paclitaxelinduced allodynia, suppresses saphenous nerve firing, and inhibits demyelination in the plantar nerve. Moreover, paeoniflorin down-regulates the paclitaxel-induced expression of CHOP in cultured Schwann cells, thereby inhibits ER stress. Adenosine $\mathrm{A}_{1}$ receptor antagonist 8-cyclopentyl-1, 3-diprooylxanrhine could inhibit attenuation of mechanical allodynia caused by paclitaxel and down-regulate CHOP levels in cell cultures induced by paeoniflorin. Hence, adenosine $\mathrm{A}_{1}$ receptor plays 
an important role in the analgesic effect of paeoniflorin (66).

\section{Affect purinergic receptors}

Adenosine triphosphate is thought to play a critical role in nociceptive transmission or pain signals. Adenosine triphosphate is implicated in peripheral pain signaling by acting on $\mathrm{P} 2 \mathrm{X}$ receptors. The seven P2X subtypes are widely expressed in many tissues (67).

P2X7 receptors have an important role in immune and pain response, and bullatine $\mathrm{A}$ as a potent P2X7 antagonist could dose-dependently inhibit ATP-induced upregulation of P2X7 mRNA, but had no obvious effect on P2X4 mRNA level in BV-2 cells. P2X pathways may be a possible mechanism for the analgesia of bullatine A (68).

\section{Inhibit c-Fos gene expression}

c-Fos has been the subject of study in relation to the pathophysiology of pain as a possible tool to aid in its understanding. In recent years, c-Fos has been used as a useful instrument for studying natural products with analgesic profile (69).

Gelsemine is effective for the treatment of neuropathic pain. After treatment with gelsemine, the mechanical thresholds and thermal latencies were prolonged in PSNL mice. A previous immunohistochemical study had shown that PSNL upregulated c-Fos expression in the neurons of the anterior cingulate cortex while gelsemine decreasedc-Fos expression by 58\% (70). Besides, intrathecal pretreatment of paeoniflorin was effective in the management of bee venom-induced pain via suppression of spinal c-Fos expression in both superficial (lamina I-II) and deep (lamina IVVI) layers of the $\mathrm{L}_{4-5}$ dorsal spine (21).

Inhibit cyclooxygenase (COX) activity and reduce the secretion of pain-causing substances

Some compounds can reduce production of cytokine substances, including interleukin (IL), tumor necrosis factor (TNF), prostaglandins, and other peripheral pain-causing substances to produce an analgesic effect. NO is a kind of important information transmitting substance and neurotransmitter. Increasing the level of cyclic guanosine monophosphate (cGMP) in target cells by NO-cGMP pathway is one of the ways in which NO participates in analgesia. Nitric oxide synthase (NOS) is a key enzyme in the synthesis of NO, and its activity changes directly regulate the amount and biological effects of NO. Berberine has significant analgesic effect, and findings on visceral hypersensitivity in rats show that berberine decrease visceral hypersensitivity by increasing NO levels. In addition, quercetin could attenuate oxaliplatininduced chronic painful peripheral neuropathy, and the mechanism is related to $\mathrm{NO}$ and peroxynitrite $(71$, 72). Lycopene, a natural pigment is recognized by the Food and Agriculture Organization of the United Nations and the World Health Organization as a class A nutrient, and it is also the hotspot in the functional food, medicine, and cosmetics industries. Lycopene can reduce diabetic neuropathic pain by inhibiting the release of $\mathrm{NO}$ and TNF- $\alpha(73,74)$.

Tetrandrine exerted strong antinociceptive effects on LPS-induced hyperalgesia in mice by inhibiting IKK $\beta$ phosphorylation, which reduced the production of important pain mediators, such as $\mathrm{PGE}_{2}$ and $\mathrm{COX}-2$, via the IKK $\beta /$ ІкВ/NF-кВ pathway (46). Meanwhile, the analgesic mechanism of tetrandrine may be through the inhibition of IL-6 production in blood and reduction of TNF- $\alpha$ level in plasma of endotoxin-induced mice (75).

Gelsemine, also known as koumine, possesses analgesic, anti-inflammatory, and neurosteroid modulating activities. Gelsemine inhibited microglial and astroglial activation in the spinal dorsal horn post-incision, and suppressed expression of pro-inflammatory cytokines IL- $1 \beta$, IL- 6 , TNF- $\alpha$ (76). Levo-tetrahydropalmatine has similar mechanism, which could inhibit the activation of microglia and increase pro-inflammatory cytokines to alleviate bone cancer pain (65).

Paeoniflorin and albiflorin could attenuate neuropathic pain by inhibiting the activation of $\mathrm{p} 38$ mitogen-activated protein kinase (p38 MAPK) pathway in spinal microglia and subsequently upregulating pro-inflammatory cytokines IL- $1 \beta$ and TNF- $\alpha$ in rats model induced by CCI (77).

Myrtenol is the main component of aromatic plant essential oil, and research shows that it could inhibit the writhing reaction of mice induced by acetic acid, but it had no significant effect on the licking time of mice in hot-plate test. The analgesic effect is also shown in the formalin experiment, but only in the second stage. Myrtenol reduces nociception in mice by inhibiting the release of inflammatory mediators, cell migration, and receptor signaling pathways involved in pain transmission (78).

Paeonol inhibits the production of $\mathrm{NO}, \mathrm{PGE}_{2}$, and IL-6 induced by LPS via prevention of ERK activation in RAW264.7 macrophages. Meanwhile, paeonol decreased protein expression of iNOS and 
COX-2 and production of pro-inflammatory cytokines, such as TNF- $\alpha$ and IL-1 $\beta$, NO and $\mathrm{PGE}_{2}$, and increased production of IL-10 in rat paw exudates of rat model of carrageenan-evoked thermal hyperalgesia $(50,79)$.

Caffeic acid, a main representative of natural phenolic compounds, is widely distributed in medicinal plants, such as Polygonum aviculare, Mentha canadaensis, Ligusticum chuanxiong, Slauia miltiorrhiza, Taraxacum mongolicum, and Artemisia capillaris $(80,81)$. Caffeic acid reduced neutrophil, free radical, and nitric oxide-mediated hypernociception as evident from the reduction in myeloperoxidase, malondialdehyde, and nitrite levels, respectively, in rat model induced by carrageenan and lipopolysaccharide (LPS)-induced mechanical hyperalgesia (80).

7-Hydroxycoumarin, also known as umbelliferone, is a coumarin found in a variety of edible fruits and plants. 7-Hydroxycoumarin has obvious analgesic effect in animal models of CFAinduced hyperalgesia by inhibiting release of TNF- $\alpha$ and IL- $1 \beta$ and the production of $\mathrm{PGE}_{2}$, directly acting as hyperalgesic mediator (82).

Quercetin alleviates $\mathrm{TiO}_{2}$-induced chronic arthritis pain in mice by inhibiting $\mathrm{TiO}_{2}$-induced neutrophil and macrophage recruitment, proteoglycan degradation, oxidative stress, cytokine production (TNF- $\alpha$, IL-1 $\beta$, IL-6, and IL-10), COX-2 mRNA expression, bone resorption, and activation of the Nrf2/HO-1 signaling pathway (83).

\section{Other analgesic mechanisms}

Geniposide, an acyclic enone glycoside compound, is one of the main active ingredients of dumplings of Gardenia jasminoides and Eucommia ulmoides. Geniposide completely protects against hydrogen peroxide-induced oxidative damage in $\mathrm{PC} 12$ and HEK293 cells that express rat and human GLP-1Rs but not in HEK293T cells that do not express GLP1Rs. The orthosteric GLP-1R antagonist exendin (939) right-shifts the concentration response curve of geniposide without changing the maximal protection, with identical pA2 values in both cell lines. Subcutaneous and oral administration of geniposide blocks the formalin-induced tonic response, with respective maximum inhibitory rates of $72 \%$ and $68 \%$ and $\mathrm{ED}_{50}$ values of 13.1 and $52.7 \mathrm{mg} / \mathrm{kg}$. Intrathecal geniposide induces dose-dependent antinociception, which is completely blocked by spinal exendin (939), siRNA/GLP-1R, and cyclic AMP/PKA pathway inhibitors. These data illustrate that geniposide exerts its analgesic effect via the spinal
GLP-1 receptors (84).

Caffeic acid potent anti-hyperglycemic inhibits thiobarbituric acid reactive substances and elevates antioxidant enzyme and attenuates alpha-amylase and alpha-glucosidase in alloxan-induced diabetic mice (85). Its elevation in serum insulin levels and its antioxidant potential might be responsible for its analgesic effect properties. Lycopene weakened neuropathic pain in mice with partial sciatic nerve ligation by up-regulating the expression of spinal astrocytic connexin 43 (86).

Pre-administration (i.t.) of PK11195, an antagonist of translocator protein $(18 \mathrm{kDa})$ partly reversed the analgesic effects of gelsemine. The analgesic mechanism of gelsemine might involve inhibition of spinal neuroinflammation and activation of translocator protein on postoperative pain rat model. Gelsemine could also regulate the biosynthesis of iso-leucine neurosteroids, which are potential therapeutic drugs that play a key role in analgesia in the spinal cord $(76,87)$.

Ellagic acid is widely distributed in in fruits and nuts, such as blueberries, blackberries, raspberries, strawberries, pomegranates, and walnuts. It has antitumor, anti-inflammatory, anti-oxidative, antidiabetic neuropathy effects, and it can inhibit $\mathrm{PGE}_{2}$ synthesis and has other pharmacological effects. Ellagic acid has peripheral and central analgesic effects, which involve the opioid receptors in the systemic and peripheral and $\mathrm{L}_{\text {-arginine-NO-cGMP- }}$ ATP-sensitive $\mathrm{K}^{+}$channel pathway (88-90).

\section{DISCUSSION}

In spite of traditional Chinese medicine has a long history in pain treatment, its active ingredients and mechanism of analgesic action is not clear. However, monomeric compounds in traditional Chinese medicine have potential applications in pain treatment. Among the compounds reviewed in this paper, some alkaloids: trilobine, palmatine, tertrandrine, berberine, govaniadine, sinomenine, gelsemine, tetrahydropalmatine, and various aconitines showed significant analgesic activities, and analgesic mechanism of them have been deeply investigated, which may be the candidate compounds for new analgesics. Then, of the 81 compounds, only tetrahydropalmatine is used as an analgesic in clinical practice. The analgesic effects of the remaining compounds were studied by animal experiments. The purpose of animal experiments is to replicate various human pains on other animals to reveal the activity of the compounds, but the 
exploration of their clinical effects cannot be limited to animal experiments. Therefore, we deem that research on clinical trials of these analgesic compounds should be strengthened to develop new analgesics.

In addition, the analgesic mechanisms of most compounds are related to glutamate receptor, central catecholaminergic system, the transient receptor potential family of ion channels, and the NO-cGMP and NF-кB pathway are also focus on the research of anti-inflammatory and analgesic drugs.

Through literature investigation, we found that only positive results of some experiments have been reported and the negative results were simply mentioned or omitted directly, so we can't summarize the negative results very well in this paper. Here, we strongly appeal to the researchers to show the negative results to the readers bravely, because the negative results are also valuable for scientific research. Sharing negative results can reduce the likelihood of peer-researcher repetition, and encourage other researchers to explore new research methods.

\section{CONCLUSION}

All in all, the study on analgesic activity of traditional Chinese medicine and natural products is more in-depth, but further researches are needed in the development of these compounds into new drugs with significant analgesic activity, which are more efficient and less toxic. Besides, there are abundant supplies of medicinal herbs from a variety of plants in China, in this case, how to use these plant resources sustainably and develop antiinflammatory and analgesic drugs with remarkable activity is one of the directions worthy of efforts in the future.

\section{ACKNOWLEDGEMENT}

The National Natural Science Foundation of China (No. 81860755), the Natural Science Foundation of Ningxia (No. NZ17090), the Key Research and Development Program of Ningxia (No. 2018BFH02001, 2018BFH03023, 2016KJHM48), Ningxia University's First-Class Subject (Traditional Chinese Medicine) Construction Project (NXYLXK2017A06), and the Ministry of Education Chunhui Project (No. Z2016064)supported this work. Thanks to Chai Xingyun research fellow (Beijing University of Chinese Medicine) for his guidance and modification of this paper.

\section{REFERENCES}

1. Cohen; Milton; Quintner; John; Rysewyk, V.; Simon. Reconsidering the international association for the study of pain definition of pain. Pain Reports 2018, latest articles (2): 1.

2. Forouzanfar, F.; Hosseinzadeh, H. Medicinal herbs in the treatment of neuropathic pain: a review. Iranian Journal of Basic Medical Sciences 2018, 21, 347-358.

3. Lutz, B.M.; Nia, S.; Xiong, M.; Tao, Y.X.; Bekker, A. Mtor, a new potential target for chronic pain and opioid-induced tolerance and hyperalgesia. Molecular Pain 2015, 11, 32.

4. Park, H.J.; Moon, D.E. Pharmacologic management of chronic pain. Korean Journal of Pain 2010, 23, 99108.

5. Garland, E.L. Treating chronic pain: The need for non-opioid options. Expert Review of Clinical Pharmacology 2014, 7, 1-6.

6. Salsitz, E.A. Chronic pain, chronic opioid addiction: A complex nexus. Journal of Medical Toxicology 2016, 12, 1-4.

7. Higgins, C.; Smith, B.H.; Matthews, K. Incidence of iatrogenic opioid dependence or abuse in patients with pain who were exposed to opioid analgesic therapy: a systematic review and meta-analysis. $\mathrm{Br} J$ Anaesth 2018, 120, 1335-1344.

8. Wang Y. Advances in pharmacy and pharmacology of analgesic Chinese medicine. Chin $J$ of Clinical Rational Drug Use 2015, 171-172.

9. Lin, A.X.; Chan, G.; Hu, Y.; Ouyang, D.; Ung, C.; Shi, L.; $\mathrm{Hu}, \mathrm{H}$. Internationalization of traditional chinese medicine: current international market, internationalization challenges and prospective suggestions. Chinese Medicine 2018, 13, 9.

10. Du, G.H.; Yuan, T.Y.; Du, L.D.; Zhang, Y.X. The potential of traditional chinese medicine in the treatment and modulation of pain. Advances in Pharmacology 2016, 75, 325.

11. Jr, W.A.V.; Vicentini; Dagger, F.T.M.C.; Baracat; Dagger, M.M.; Geor, S.R. Flavonoids as antiinflammatory and analgesic drugs: mechanisms of action and perspectives in the development of pharmaceutical forms. 2012; 297-330.

12. Bonjardim, L.R.; Cunha, E.S.; Guimarães, A.G.; Santana, M.F.; Oliveira, M.G.; Serafini, M.R.; Araújo, A.A.; Antoniolli, A.R.; Cavalcanti, S.C.; Santos, M.R. Evaluation of the anti-inflammatory and antinociceptive properties of $p$-cymene in mice. Zeitschrift Für Naturforschung C 2012, 67, 15-21.

13. de Santana, M.F.; Guimarães, A.G.; Chaves, D.O.; Silva, J.C.; Bonjardim, L.R.; De, L.J.W.; Ferro, J.N.; Barreto, E.O.; dos Santos, F.E.; Soares, M.B. The anti-hyperalgesic and anti-inflammatory profiles of $p$-cymene: evidence for the involvement of opioid system and cytokines. Pharmaceutical Biology 2015, $53,1583-1590$. 
14. Liu, B.; Fan, L.; Balakrishna, S.; Sui, A.; Morris, J.B.; Jordt, S.E. TRPM8 is the principal mediator of menthol-induced analgesia of acute and inflammatory pain. Pain 2013, 154, 2169.

15. Galeotti, N.; Mannelli, L.D.C.; Mazzanti, G.; Bartolini, A.; Ghelardini, C. Menthol: A natural analgesic compound. Neuroscience Letters 2002, 322, 145-148.

16. Kwak, J. Acute Effects of Capsaicin on Proopioimelanocortin mRNA Levels in the Arcuate Nucleus of Sprague-Dawley Rats. Psychiatry Investigation 2012, 9(2): 187-190.

17. Sun, J.; Yu, S. Research progress of quercetin. Chin Med J Res Prac 2011, 85-88.

18. Mittal, N.; Joshi, R.; Hota, D.; Chakrabarti, A. Evaluation of antihyperalgesic effect of curcumin on formalin-induced orofacial pain in rat. Phytotherapy Research Ptr 2009, 23, 507-512.

19. Muhammad, N.; Shrestha, R.L.; Adhikari, A.; Wadood, A.; Khan, H.; Khan, A.Z.; Maione, F.; Mascolo, N.; De, F.V. First evidence of the analgesic activity of govaniadine, an alkaloid isolated from Corydalis govaniana wall. Natural Product Research 2015, 29, 430-437.

20. Long, Z.; Zhang, Y.; Guo, Z.; Wang, L.; Xue, X.; Zhang, X.; Wang, S.; Wang, Z.; Civelli, O.; Liang, X. Amide alkaloids from Scopolia tangutica. Planta Medica 2014, 80, 1124-1130.

21. Yu, H.Y.; Mu, D.; Chen, J.; Yin, W. Suppressive effects of intrathecal paeoniflorin on bee venominduced pain-related behaviors and spinal neuronal activation. Pharmacology 2011, 88, 159-166.

22. Loscalzo, L.M.; Wasowski, C.; Paladini, A.C.; Marder, M. Opioid receptors are involved in the sedative and antinociceptive effects of hesperidin as well as in its potentiation with benzodiazepines. European Journal of Pharmacology 2008, 580, 306313.

23. Loscalzo, L.M.; Yow, T.T.; Wasowski, C.; Chebib, M.; Marder, M. Hesperidin induces antinociceptive effect in mice and its aglycone, hesperetin, binds to $\mu$ opioid receptor and inhibits GIRK $1 / 2$ currents. Pharmacology Biochemistry \& Behavior 2011, 99, 333-341.

24. Huang, Q.; Mao, X.F.; Wu, H.Y.; Li, T.F.; Sun, M.L.; Liu, H.; Wang, Y.X. Bullatine A stimulates spinal microglial dynorphin A expression to produce antihypersensitivity in a variety of rat pain models. Journal of Neuroinflammation 2016, 13, 214.

25. Rigo, F.K.; Rossato, M.F.; Trevisan, G.; De Prá, S.D.; Ineu, R.P.; Duarte, M.B.; Cj, D.C.J.; Ferreira, J.; Gomez, M.V. PhKv a toxin isolated from the spider venom induces antinociception by inhibition of cholinesterase activating cholinergic system. Scandinavian Journal of Pain 2017, 17, 203.

26. Yin, L.L.; Zhu, X.Z. The involvement of central cholinergic system in (+)-matrine-induced antinociception in mice. Pharmacology Biochemistry \& Behavior 2005, 80, 419-425.

27. Zuo, Z.X.; Wang, Y.J.; Li, L.; Wang, Y.; Mei, S.H.; Feng, Z.H.; Wang, M.; Li, X.Y. Huperzine A alleviates mechanical allodynia but not spontaneous pain via muscarinic acetylcholine receptors in mice. Neural Plasticity, 2015,(2015-12-1) 2015, 2015, 1-11.

28. Murayama, M.; Ito, T.; Konno, C.; Hikino, H. Mechanism of analgesic action of mesaconitine. Relationship between analgesic effect and central monoamines or opiate receptors. European Journal of Pharmacology 1984, 101, 29-36.

29. Ameri, A.; Seitz, U. Effects of mesaconitine on $[3 \mathrm{H}]$ noradrenaline uptake and neuronal excitability in rat hippocampus. Experimental Brain Research.experimentelle

Hirnforschung.expérimentation Cérébrale 1998, 121, 451-456.

30. Ono, M.; Satoh, T. Pharmacological studies on lappaconitine: Possible interaction with endogenous noradrenergic and serotonergic pathways to induce antinociception. Japanese Journal of Pharmacology 1992, 58, 251-257.

31. Leeab, K.K.; Yuzurihara, M.; Kase, Y.; Kobayashi, H. Antinociceptive effect of paeoniflorin via spinal $\alpha$ adrenoceptor activation in diabetic mice. European Journal of Pain 2011, 15, 1035-1039.

32. Zhou, H.H.; Wu, D.L.; Gao, L.Y.; Fang, Y.; Ge, W.H. L-tetrahydropalmatine alleviates mechanical hyperalgesia in models of chronic inflammatory and neuropathic pain in mice. Neuroreport 2016, 27, 476480.

33. Wu, Y.Y.; Jiang, Y.L.; He, X.F.; Zhao, X.Y.; Shao, X.M.; Sun, J.; Shen, Z.; Shou, S.Y.; Wei, J.J.; Ye, J.Y., et al. 5-HT in the dorsal raphe nucleus is involved in the effects of $100-\mathrm{Hz}$ electro-acupuncture on the pain-depression dyad in rats. Exp Ther Med 2017, 14, 107-114.

34. Carballo-Villalobos, A.I.; González-Trujano, M.E.; López-Muñoz, F.J. Evidence of mechanism of action of anti-inflammatory/antinociceptive activities of acacetin. European Journal of Pain 2014, 18, 396405.

35. Martínez, A.L.; González-Trujano, M.E.; AguirreHernández, E.; Moreno, J.; Soto-Hernández, M.; López-Muñoz, F.J. Antinociceptive activity of Tilia americana var. mexicana inflorescences and quercetin in the formalin test and in an arthritic pain model in rats. Neuropharmacology 2009, 56, 564571.

36. Wang, Z.J.; Heinbockel, T. Essential oils and their constituents targeting the gabaergic system and sodium channels as treatment of neurological diseases. Molecules 2018, 23, 1061.

37. Zhu, Q.; Sun, Y.; Zhu, J.; Fang, T.; Zhang, W.; Li, J.X. Antinociceptive effects of sinomenine in a rat model of neuropathic pain. Scientific Reports 2014, 4, 7270. 
38. Zhai, K.; Hu, L.; Chen, J.; Fu, C.Y.; Chen, Q. Chrysin induces hyperalgesia via the GABAA receptor in mice. Planta Medica 2008, 74, 1229-1234.

39. Zhou, J.; Yang, G.; Jin, S.; Tao, L.; Yu, J.; Jiang, Y. Oxymatrine-carbenoxolone sodium inclusion compound induces antinociception and increases the expression of GABA(A)alphal receptors in mice. European Journal of Pharmacology 2010, 626, 244249.

40. Nazıroğlu, M.; Braidy, N. Thermo-sensitive TRP channels: novel targets for treating chemotherapyinduced peripheral pain. Frontiers in Physiology 2017, 8 .

41. Hu, J.; Shi, X.; Mao, X.; Chen, J.; Zhu, L.; Zhao, Q. Antinociceptive activity of Rhoifoline A from the ethanol extract of Zanthoxylum nitidum in mice. Journal of Ethnopharmacology 2013, 150, 828-834.

42. Chen, Z.; Ma, C.; Xu, S. Analgesic mechanism of hyperin.Acta Pharmaceutica Sinica 1989, 326-330.

43. Lee, J.Y.; Yoon, S.Y.; Won, J.; Kim, H.B.; Kang, Y.; Oh, S.B. Sinomenine produces peripheral analgesic effects via inhibition of voltage-gated sodium currents. Neuroscience 2017, 358, 28-36.

44. Wu, S.; Yang, L.; Lv, X. Study on analgesia of oxymatrine and its relation to calcium channels.Chinese Journal of Integrated Traditional and Western 2015, 35, 461-465.

45. Wang, Y.; Yuan, J.; Yuan, X.; Wang, W.; Pei, X.; Zhao, Q.; Cao, H.; Xu, M.; Liu, Z. Observation of antinociceptive effects of oxymatrine and its effect on delayed rectifier K currents (IK) in PC12 cells. Neurochemical Research 2012, 37, 2143-2149.

46. Zhao, H.; Luo, F.; Li, H.; Li, Z.; Yi, Y.; Wan, J. Antinociceptive effect of tetrandrine on LPS-induced hyperalgesia via the inhibition of IKK $\beta$ phosphorylation and the $\mathrm{COX}-2 / \mathrm{PGE}_{2}$ pathway in mice. Plos One 2014, 9, 94586.

47. Song, B.; Zhang, J.; Chen, Z.; Ma, C.;Xu, S.; Fang, M.; Zhang, Y. Effect of calcium ion on analgesic effect of tetrandrine. Acta Universitatis Medicinalis Anhui 1995, 1-3.

48. Pan, R.; Tian, Y.; Gao, R.; Li, H.; Zhao, X.; Barrett, J.E.; Hu, H. Central mechanisms of menthol-induced analgesia. Journal of Pharmacology \& Experimental Therapeutics 2012, 343, 661-672.

49. He, Q.L.; Chen, Y.; Jian, Q.; Mo, S.L.; Ming, W.; Zhang, J.J.; Li, M.N.; Zou, X.N.; Zhou, S.F.; Chen, $\mathrm{X}$.W. Osthole, a herbal compound, alleviates nucleus pulposus-evoked nociceptive responses through the suppression of overexpression of acid-sensing ion channel 3 (ASIC3) in rat dorsal root ganglion. Medical Science Monitor International Medical Journal of Experimental \& Clinical Research 2012, 18, BR229-BR236.

50. Wu, H.X.; Wang, Y.M.; Xu, H.; Wei, M.; He, Q.L.; Li, M.N.; Sun, L.B.; Cao, M.H. Osthole, a coumadin analog from Cnidium monnieri (L.) cusson, ameliorates nucleus pulposus-induced radicular inflammatory pain by inhibiting the activation of extracellular signal-regulated kinase in rats. Pharmacology 2017, 100, 74-82.

51. Kantamneni, S. Cross-talk and regulation between glutamate and GABAB receptors. Frontiers in Cellular Neuroscience 2015, 9, 135.

52. Zhang, J.Y.; Gong, N.; Huang, J.L.; Guo, L.C.; Wang, Y.X. Gelsemine, a principal alkaloid from Gelsemium sempervirens Ait., exhibits potent and specific antinociception in chronic pain by acting at spinal $\alpha 3$ glycine receptors. Pain $®$ 2013, 154, 2452.

53. Lara, C.O.; Murath, P.; Muñoz, B.; Marileo, A.M.; Martín, L.S.; San Martín, V.P.; Burgos, C.F.; Mariqueo, T.A.; Aguayo, L.G.; Fuentealba, J. Functional modulation of glycine receptors by the alkaloid gelsemine. British Journal of Pharmacology 2016, 173, 2263-2277.

54. Sun, G.P.; Wang, H.; Xu, S.P.; Shen, Y.X.; Wu, Q.; Chen, Z.D.; Wei, W. Anti-tumor effects of paeonol in a HepA-hepatoma bearing mouse model via induction of tumor cell apoptosis and stimulation of IL-2 and TNF-alpha production. European Journal of Pharmacology 2008, 584, 246-252.

55. Wang, D. The effects and mechanisms of peaonol and ZBD-2 in chronic inflammatory pain induced by complete Freund's adjuvant in mice. The Second Military medical university 2016.

56. Wang, H.; Li, Y.; Dun, L.; Xu, Y.; Jin, S.; Du, J.; Ma, L.; Li, J.; Zhou, R.; He, X. Antinociceptive effects of oxymatrine from Sophora flavescens, through regulation of NR2B-containing NMDA receptorERK/CREB signaling in a mice model of neuropathic pain. Phytomedicine International Journal of Phytotherapy \& Phytopharmacology 2013, 20, 10391045.

57. Zhang, X.J.; Chen, H.L.; Li, Z.; Zhang, H.Q.; Xu, H.X.; Sung, J.J.; Bian, Z.X. Analgesic effect of paeoniflorin in rats with neonatal maternal separation-induced visceral hyperalgesia is mediated through adenosine $A_{1}$ receptor by inhibiting the extracellular signal-regulated protein kinase (ERK) pathway. Pharmacology Biochemistry \& Behavior 2009, 94, 88-97.

58. Jin-Seong, L.; Sung-Gon, K.; Hyeun-Kyeung, K.; Sun-Yong, B.; Cheol-Min, K. Acute effects of capsaicin on proopioimelanocortin mRNA levels in the arcuate nucleus of Sprague-Dawley rats. Psychiatry Investigation 2012, 9, 187-190.

59. Montrucchio, D.P.; Córdova, M.M.; Santos, A.R.S. Plant derived aporphinic alkaloid S-(+)-dicentrine induces antinociceptive effect in both acute and chronic inflammatory pain models: evidence for a role of TRPA1 channels. Plos One 2013, 8, 88-91.

60. Wang, S.; Zhang, D.; Hu, J.; Jia, Q.; Xu, W.; Su, D.; Song, H.; Xu, Z.; Cui, J.; Zhou, M. A clinical and mechanistic study of topical borneol-induced 
analgesia. EMBO Molecular Medicine,9,6(2017-0410) 2017, 9, 802-815.

61. Takaishi, M.; Fujita, F.; Uchida, K.; Yamamoto, S.; Sawada, M.; Hatai, C.; Shimizu, M.; Tominaga, M. 1,8-cineole, a TRPM8 agonist, is a novel natural antagonist of human TRPA1. Molecular Pain 2012, 8.

62. Pinhoribeiro, F.A.; Hohmann, M.S.; Borghi, S.M.; Zarpelon, A.C.; Guazelli, C.F.; Manchope, M.F.; Casagrande, R.; Jr, V.W. Protective effects of the flavonoid hesperidin methyl chalcone in inflammation and pain in mice: Role of TRPV1, oxidative stress, cytokines and NF- $\kappa \mathrm{B}$. ChemicoBiological Interactions 2015, 228, 88-99.

63. Lee, J.Y.; Shin, T.J.; Choi, J.M.; Seo, K.S.; Kim, H.J.; Yoon, T.G.; Lee, Y.S.; Han, H.; Chung, H.J.; Oh, Y. Antinociceptive curcuminoid, KMS4034, effects on inflammatory and neuropathic pain likely via modulating TRPV1 in mice. Br J Anaesth 2013, 111, 667-672.

64. Wang, M.L.; Yu, G.; Yi, S.P.; Zhang, F.Y.; Wang, Z.T.; Huang, B.; Su, R.B.; Jia, Y.X.; Gong, Z.H. Antinociceptive effects of incarvillateine, a monoterpene alkaloid from Incarvillea sinensis, and possible involvement of the adenosine system. Scientific Reports 2015, 5, 16107.

65. Zhang, M.; Liu, Y.; Zhang, L.; Yue, D.; Qi, D.; Liu, G.; Liu, S. Levo-tetrahydropalmatine attenuates bone cancer pain by inhibiting microglial cells activation. Mediators of Inflammation 2015, 2015, 752512.

66. Andoh, T.; Kobayashi, N.; Uta, D.; Kuraishi, Y. Prophylactic topical paeoniflorin prevents mechanical allodynia caused by paclitaxel in mice through adenosine $\mathrm{A}_{1}$ receptors. Phytomedicine International Journal of Phytotherapy \& Phytopharmacology 2017, 25, 1.

67. Liang, S.; Xu, C.; Li, G.; Gao, Y. P2X receptors and modulation of pain transmission: focus on effects of drugs and compounds used in traditional chinese medicine. Neurochemistry International 2010, 57, 705-712.

68. Li, J.; Ren, W.; Huang, X.J.; Zou, D.J.; Hu, X. Bullatine A, a diterpenoid alkaloid of the genus Aconitum, could attenuate ATP-induced BV-2 microglia death/apoptosis via $\mathrm{P} 2 \mathrm{X}$ receptor pathways. Brain Research Bulletin 2013, 97, 81-85.

69. Santos, P.L.; Brito, R.G.; Jpscf, M.; Jss, Q.; Quintansjúnior, L.J. Fos protein as a marker of neuronal activity: a useful tool in the study of the mechanism of action of natural products with analgesic activity. Molecular Neurobiology 2017, 2017, 1-20.

70. Wu, Y.; Li, Y.; Luo, Y.; Wang, T.; Wang, H.; Chen, S.; $\mathrm{Qu}, \mathrm{W}$; Huang, Z. Gelsemine alleviates both neuropathic pain and sleep disturbance in partial sciatic nerve ligation mice. Acta Pharmacologica Sinica 2015, 36, 1308-1317.
71. Tang, Q.L.; Lai, M.L.; Zhong, Y.F.; Wang, A.M.; Su, J.K.; Zhang, M.Q. Antinociceptive effect of berberine on visceral hypersensitivity in rats. World Journal of Gastroenterology 2013, 19, 4582-4589.

72. Azevedo, M.I.; Pereira, A.F.; Nogueira, R.B.; Rolim, F.E.; Brito, G.A.; Wong, D.V.; Limajúnior, R.C.; De, A.R.R.; Vale, M.L. The antioxidant effects of the flavonoids rutin and quercetin inhibit oxaliplatininduced chronic painful peripheral neuropathy. Molecular Pain 2013, 9, 53.

73. Liu, Y.; Li, J.; Yan, W.; Hao, L.; Zhao, E. Study on the ultrasonic-assisted extraction and antioxidant activities oflycopene from cherry tomatoes. Storage and Process 2017, 73-77.

74. Kuhad, A.; Sharma, S.; Chopra, K. Lycopene attenuates thermal hyperalgesia in a diabetic mouse model of neuropathic pain. European Journal of Pain 2008, 12, 624-632.

75. Dai, X; Luo, F.; Zhang, Z.; Li, H.; Zhang, L.; Wan, J. Studies on analgesic effect and mechanism of tetrandrine on lipopolysaccharide-induced hyperalgsia in mice. Lishizhen Medicine and Materia Medica Research 2010, 21, 1049-1050.

76. Xiong, B.J.; Xu, Y.; Jin, G.L.; Liu, M.; Yang, J.; Yu, C.X. Analgesic effects and pharmacologic mechanisms of the gelsemium alkaloid koumine on a rat model of postoperative pain. Sci Rep 2017, 7, 14269.

77. Zhou, J.; Wang, L.; Wang, J.; Wang, C.; Yang, Z.; Wang, C.; Zhu, Y.; Zhang, J. Paeoniflorin and albiflorin attenuate neuropathic pain via mapk pathway in chronic constriction injury rats. EvidenceBased Complementray and Alternative Medicine, 2016, 2016, 1-11.

78. Silva, R.O.; Salvadori, M.S.; Sousa, F.B.M.; Santos, M.S.; Carvalho, N.S.; Sousa, D.P.; Gomes, B.S.; Oliveira, F.A.; Barbosa, A.L.R.; Freitas, R.M. Evaluation of the anti-inflammatory and antinociceptive effects of myrtenol, a plant-derived monoterpene alcohol, in mice. Flavour \& Fragrance Journal 2014, 29, 184-192.

79. Tosun, A.; Akkol, E.K.; Yeşilada, E. Antiinflammatory and antinociceptive activity of coumarins from Seseli gummiferum subsp. corymbosum (Apiaceae). Zeitschrift Fur Naturforschung Section C-a Journal of Biosciences 2009, 64, 56-62.

80. Mehrotra, A.; Shanbhag, R.; Chamallamudi, M.R.; Singh, V.P.; Mudgal, J. Ameliorative effect of caffeic acid against inflammatory pain in rodents. European Journal of Pharmacology 2011, 666, 80.

81. Editorial boardo of State Administration of Traditional Chinese Medicine. Zhonghuabencao. The Press of Science and technology of Shanghai: 2009.

82. de Lima, F.O.; Nonato, F.R.; Couto, R.D.; Barbosa Filho, J.M.; Nunes, X.P.; Ribeiro, d.S.R.; Soares, 
M.B.; Villarreal, C.F. Mechanisms involved in the antinociceptive effects of 7-hydroxycoumarin. Journal of Natural Products 2011, 74, 596.

83. Borghi, S.M.; Mizokami, S.S.; Pinhoribeiro, F.A.; Fattori, V.; Crespigio, J.; Clementenapimoga, J.T.; Napimoga, M.H.; Pitol, D.L.; Issa, J.; Fukada, S.Y. The flavonoid quercetin inhibits titanium dioxide (TIO2)-induced chronic arthritis in mice. Journal of Nutritional Biochemistry 2018, 53, 81-95.

84. Gong, N.; Fan, H.; Ma, A.N.; Xiao, Q.; Wang, Y.X. Geniposide and its iridoid analogs exhibit antinociception by acting at the spinal GLP-1 receptors. Neuropharmacology 2014, 84, 31-45.

85. Raafat, K.; Wurglics, M.; Schubert-Zsilavecz, M. Prunella vulgaris L. active components and their hypoglycemic and antinociceptive effects in alloxaninduced diabetic mice. Biomedicine \& Pharmacotherapy 2016, 84, 1008-1018.

86. Zhang, F.F.; Morioka, N.; Kitamura, T.; Fujii, S.; Miyauchi, K.; Nakamura, Y.; Hisaoka-Nakashima, K.; Nakata, Y. Lycopene ameliorates neuropathic pain by upregulating spinal astrocytic connexin 43 expression. Life Sciences 2016, 155, 116-122.

87. Venard, C.; Boujedaini, N.; Belon, P.; MensahNyagan, A.G.; Patte-Mensah, C. Regulation of neurosteroid allopregnanolone biosynthesis in the rat spinal cord by glycine and the alkaloidal analogs strychnine and gelsemine. Neuroscience 2008, 153, 154-161.

88. Taghi, M.M.; Naghizadeh, B.; Ghorbanzadeh, B.; Farbood, Y. Central and peripheral antinociceptive effects of ellagic acid in different animal models of pain. European Journal of Pharmacology 2013, 707, 46-53.

89. Mansouri, M.T.; Naghizadeh, B.; Ghorbanzadeh, B. Involvement of opioid receptors in the systemic and peripheral antinociceptive actions of ellagic acid in the rat formalin test. Pharmacology Biochemistry \& Behavior 2014, 120, 43-49.

90. Ghorbanzadeh, B.; Mansouri, M.T.; Hemmati, A.A.; Naghizadeh, B.; Mard, S.A.; Rezaie, A. Involvement of L-arginine/NO/cGMP/K(ATP) channel pathway in the peripheral antinociceptive actions of ellagic acid in the rat formalin test. Pharmacology Biochemistry \& Behavior 2014, 126, 116-121.

91. Sun, W. Brief manual for natural active ingredients.China Medical Science Press: 1998.

92. Chao, J.; Liao, J.W.; Peng, W.H.; Lee, M.S.; Pao, L.H.; Cheng, H.Y. Antioxidant, analgesic, antiinflammatory, and hepatoprotective effects of the ethanol extract of Mahonia oiwakensis stem. International Journal of Molecular Sciences 2013 , 14, 2928.

93. Liu, X.; Hu, Z.; Shi, Q.; Zeng, H.; Shen, Y.; Jin, H.; Zhang, W. Anti-inflammatory and anti-nociceptive activities of compounds from Tinospora sagittata (Oliv.) Gagnep. Archives of Pharmacal Research
2010, 33, 981 .

94. Chen, F. Determination of active ingredients in traditional Chinese medicine. People's Medical Publishing House: 2008.

95. Wang, L. Experimental study on the analgesie effect and mechanism of propofol. Soochow University, 2002.

96. Deng, Z.; Yu, S.; Ke, F.; Chen, J.; Huang, Yu.; Huang, D. Dicentrine, a natural vascular $\alpha_{1}$-adrenoceptor antagonist, isolated form Lindera megaphylla. British Journal of Pharmacology 1991, v.104.

97. Tsai, T.H.; Wang, G.J.; Lin, L.C. Vasorelaxing alkaloids and flavonoids from Cassytha filiformis. Journal of Natural Products 2008, 71, 289-291.

98. Shamima, A.R.; Fakurazi, S.; Hidayat, M.T.; Hairuszah, I.; Moklas, M.A.; Arulselvan, P. Antinociceptive action of isolated mitragynine from Mitragyna speciosa through activation of opioid receptor system. International Journal of Molecular Sciences 2012, 13, 11427-11442.

99. Farzin, D.; Kalantari, P.; Zaer, H. Effects of harmane, norharman and harmine on the hot-plate and formalin-induced nociceptions in mice. Journal of Mazandaran University of Medical Sciences 2012.

100.Jiang, H.; Liu, Y.B.; Li, Y.; Li, L.; Ma, S.G.; Qu, J.; Yu, S.S. Analgesic corynanthe-type alkaloids from Strychnos angustiflora. Tetrahedron 2016, 72, 12761284.

101.Ma, X.; Jiang, S. Diterpenoid alkaloids from Aconitum bulleyanum Diels. China Journal of Chinese Materia Medica 1998, 23, 679-680.

102. Guo, Z. A preliminary research on the quality control of the processed products of radix aconitum vilmoriniani. Yunnan University of TCM, 2015.

103.Wang, D.P.; Lou, H.Y.; Huang, L.; Hao, X.J.; Liang, G.Y.; Yang, Z.C.; Pan, W.D. A novel franchetine type norditerpenoid isolated from the roots of Aconitum carmichaeli Debx. with potential analgesic activity and less toxicity. Cheminform 2012, 22, 4444-4446.

104.Zhao, D.K.; Ai, H.L.; Zi, S.H.; Zhang, L.M.; Yang, S.C.; Guo, H.C.; Shen, Y.; Chen, Y.P.; Chen, J.J. Four new $\mathrm{C}_{18}$-diterpenoid alkaloids with analgesic activity from Aconitum weixiense. Fitoterapia 2013, 91, 280283.

105.Guo, Q.; Xia, H.; Shi, G.; Zhang, T.; Shi, J. Aconicarmisulfonine a, a Sulfonated $\mathrm{C}_{20}$-diterpenoid alkaloid from the Lateral roots of Aconitum carmichaelii. Organic Letters 2018, 816-819.

106. Alexandre-Moreira, M.S.; Jr, V.C.; A1, P.D.M.; Bolzani, V.S.; Barreiro, E.J. Antinociceptive profile of (-)-spectaline: a piperidine alkaloid from Cassia leptophylla. Planta Medica 2003, 69, 795-799.

107.Jr, V.C.; Alexandremoreira, M.S.; Fraga, C.A.; Barreiro, E.J.; Bolzani, V.S.; de Miranda, A.L. Antinociceptive profile of 2,3,6-trisubstituted piperidine alkaloids: 3 -O-acetyl-spectaline and semisynthetic derivatives of (-)-spectaline. Chemical \& 
Pharmaceutical Bulletin 2008, 56, 407-412.

108.Li, Q.; Yang, K.X.; Zhao, Y.L.; Qin, X.J.; Yang, X.W.; Liu, L.; Liu, Y.P.; Luo, X.D. Potent antiinflammatory and analgesic steroidal alkaloids from Veratrum taliense. Journal of Ethnopharmacology 2015, 179, 274-279.

109. Fazal-ur-Rehman; Khan, M.F.; Khan, I.; Shareef, H.; Marwat, S.K. Analgesic activity of carbazole alkaloid from Murraya paniculata Linn. (Rutaceae). World Applied Sciences Journal 2014.

110. Rauf, A.; Khan, R.; Raza, M.; Khan, H.; Pervez, S.; De, F.V.; Maione, F.; Mascolo, N. Suppression of inflammatory response by chrysin, a flavone isolated from Potentilla evestita Th. Wolf. In silico predictive study on its mechanistic effect. Fitoterapia 2015, 103, 129-135.

111.Jeong, J.H.; Moon, S.J.; Jhun, J.Y.; Yang, E.J.; Cho, M.L.; Min, J.K. Eupatilin exerts antinociceptive and chondroprotective properties in a rat model of osteoarthritis by downregulating oxidative damage and catabolic activity in chondrocytes. Plos One 2015, 10, e0130882.

112. Rauf, A.; Khan, R.; Khan, H.; Ullah, B.; Pervez, S. Antipyretic and antinociceptive potential of extract/fractions of Potentilla evestita and its isolated compound, acacetin. Bmc Complementary \& Alternative Medicine 2014, 14, 448.

113. Raafat, K.; Ellakany, A. Acute and subchronic invivo effects of Ferula hermonis L. and sambucus nigra L. and their potential active isolates in a diabetic mouse model of neuropathic pain. Bmc Complementary \& Alternative Medicine 2015, 15, 114.

114.Parveen, Z.; Deng, Y.; Saeed, M.K.; Dai, R.; Ahamad, W.; Yu, Y.H. Antiinflammatory and analgesic activities of Thesium chinense Turcz extracts and its major flavonoids, kaempferol and kaempferol-3-Oglucoside. Yakugaku Zasshi-journal of the Pharmaceutical Society of Japan 2007, 127, 1275 1279.

115.Ali, M.; Khan, S.A.; Rauf, A.; Khan, H.; Shah, M.R.; Ahmad, M.; Mubarak, M.S.; Hadda, T.B. Characterization and antinociceptive activity (in vivo) of kempferol-3, 4'-di-O- $\alpha$-L-rhamnopyranoside isolated from Dryopteris cycadina. Medicinal Chemistry Research 2015, 24, 3218-3229.

116. Meotti, F.C.; Luiz, A.P.; Pizzolatti, M.G.; Kassuya, C.A.; Calixto, J.B.; Santos, A.R. Analysis of the antinociceptive effect of the flavonoid myricitrin: evidence for a role of the L-arginine-nitric oxide and protein kinase C pathways. Journal of Pharmacology \& Experimental Therapeutics 2006, 316, 789-796.

117.Chandra, M.; Prakash, O.; Kumar, R.; Bachheti, R.K.; Bhushan, B.; Kumar, M.; Pant, A.K. $\quad \beta$-Selinene-rich essential oils from the parts of Callicarpa macrophylla and their antioxidant and pharmacological activities. Medicines 2017, 4, 52.
118. Masoumiardakani, Y.; Mandegary, A.; Esmaeilpour, K.; Najafipour, H.; Sharififar, F.; Pakravanan, M.; Ghazvini, H. Chemical composition, anticonvulsant activity, and toxicity of essential oil and methanolic extract of elettaria cardamomum. Planta Medica 2016, $82,1482-1486$.

119.La Rocca, V.; Fonsêca, D.V.D.; Silva-Alves, K.S.; Santos, P.L. Geraniol induces antinociceptive effect in mice evaluated in behavioural and electrophysiological models. Basic \& Clinical Pharmacology \& Toxicology 2016, 120.

120. Young, H.Y.; Luo, Y.L.; Cheng, H.Y.; Hsieh, W.C.; Liao, J.C.; Peng, W.H. Analgesic and antiinflammatory activities of [6]-gingerol. Journal of Ethnopharmacology 2005, 96, 207-210.

121.Choi, J.; Shin, K.M.; Park, H.J.; Jung, H.J.; Kim, H.J.; Lee, Y.S.; Rew, J.H.; Lee, K.T. Anti-inflammatory and antinociceptive effects of sinapyl alcohol and its glucoside syringin. Planta Medica 2004, 70, 1027 1032.

122.Liao, J.C.; Deng, J.S.; Lin, Y.C.; Lee, C.Y.; Lee, M.M.; Hou, W.C.; Huang, S.S.; Huang, G.J. Antioxidant, antinociceptive, and anti-inflammatory activities from Actinidia callosa var. callosa in vitro and in vivo. Evid Based Complement Alternat Med 2012, 2012, 1325-1325.

123.Chen, Y.F.; Tsai, H.Y.; Wu, T.S. Anti-inflammatory and analgesic activities from roots of Angelica pubescens. Planta Medica 1995, 61, 2.

124.Ye, H.; Xiong, X.; Qiu, W.; Wang, Z.; Xiao, H.; He, W.; Liu, J.; Zeng, J. Analgesic effect of daphnetin in mice with pain due to acetic acid, hot board and electric stimulation.Chinese Journal of Clinical Rehabilitation 2005, 9, 174-176.

125.Choi, S.S.; Han, K.J.; Lee, J.K.; Lee, H.K.; Han, E.J.; Kim, D.H.; Suh, H.W. Antinociceptive mechanisms of orally administered decursinol in the mouse. Life Sciences 2003, 73, 471-485.

126.Wu, L.; Li, P.; Wang, X.; Zhuang, Z.; Farzaneh, F.; $\mathrm{Xu}, \mathrm{R}$. Evaluation of anti-inflammatory and antinociceptive activities of Murraya exotica. Pharm Biol 2010, 48, 1344-1353.

127.Li, R.; Zhao, C.; Yao, M.; Song, Y.; Wu, Y.; Wen, A. Analgesic effect of coumarins from Radix angelicae pubescentis is mediated by inflammatory factors and TRPV1 in a spared nerve injury model of neuropathic pain. Journal of Ethnopharmacology 2016, 195, 8188.

128.Chang, T.N.; Deng, J.S.; Chang, Y.C.; Lee, C.Y.; Liao, J.C.; Lee, M.M.; Peng, W.H.; Huang, S.S.; Huang, G.J. Ameliorative effects of scopoletin from Crossostephium chinensis against inflammation pain and its mechanisms in mice. Evidence-Based Complementray and Alternative Medicine,2012,(2012-9-6) 2012, 2012, 595603.

129.Mahendran, S.; Badami, S.; Ravi, S.; Thippeswamy, B.S.; Veerapur, V.P. Synthesis and evaluation of 
analgesic and anti-inflammatory activities of most active free radical scavenging derivatives of embelina structure-activity relationship. Chemical \& Pharmaceutical Bulletin 2011, 59, 913-919.

130.Zheng, L; Tan,J.; Tang, X. Analgesic,antipyretic effects and no addictive of Tetrandrine. Academic Journal of Second Military Medical University 1984.

131.Küpeli, E.; Koşar, M.; Yeşilada, E.; Hüsnü, K.; Başer, C. A comparative study on the anti-inflammatory, antinociceptive and antipyretic effects of isoquinoline alkaloids from the roots of Turkish berberis species. Life Sciences 2002, 72, 645.

132.Zhao, H.; Luo, F.; Li, H.; Zhang, L.; Yi, Y.; Wan, J. Antinociceptive effect of tetrandrine on LPS-induced hyperalgesia via the inhibition of IKK $\beta$ phosphorylation and the $\mathrm{COX}-2 / \mathrm{PGE}_{2}$ pathway in mice. Plos One 2014, 9, e94586.

133.Zhang, M. Pharmacological effects of sinomenine. Shaanxi Medical Journal 1981.

134.Zhu, Q.; Sun, Y.; Mao, L.; Liu, C.; Jiang, B.; Zhang, W.; Li, J.X. Antinociceptive effects of sinomenine in a rat model of postoperative pain. British Journal of Pharmacology 2016, 173, 1693.

135. Gao, T.; Hao, J.; Wiesenfeld-Hallin, Z.; Wang, D.Q.; $\mathrm{Xu}, \mathrm{X} . J$. Analgesic effect of sinomenine in rodents after inflammation and nerve injury. European Journal of Pharmacology 2013, 721, 5-11.

136.Kang, D.W.; Moon, J.Y.; Choi, J.G.; Kang, S.Y.; Ryu, Y.; Jin, B.P.; Lee, J.H.; Kim, H.W. Antinociceptive profile of levo-tetrahydropalmatine in acute and chronic pain mice models: role of spinal sigma-1 receptor. Sci Rep 2016, 6, 37850.

137.Cao, F.L.; Shang, G.W.; Wang, Y.; Yang, F.; Li, C.L.; Chen, J. Antinociceptive effects of intragastric DLtetrahydropalmatine on visceral and somatic persistent nociception and pain hypersensitivity in rats. Pharmacology Biochemistry \& Behavior 2011, 100, 199.

138. Tan, J.; Qiu, C.; Zheng, L. Analgesic effect and no tolerance of gelsemide, Pharmacology and Clinics of Chinese Materia Medica 1988.

139.Xu, Y.; Qiu, H.Q.; Liu, H.; Liu, M.; Huang, Z.Y.; Yang, J.; Su, Y.P.; Yu, C.X. Effects of koumine, an alkaloid of Gelsemium elegans Benth., on inflammatory and neuropathic pain models and possible mechanism with allopregnanolone. Pharmacology Biochemistry \& Behavior 2012, 101, 504-514.

140.Ling, Q.; Liu, M.; Wu, M.X.; Xu, Y.; Yang, J.; Huang, H. H.; Yu, C.X. Anti-allodynic and neuroprotective effects of koumine, a benth alkaloid, in a rat model of diabetic neuropathy. Biological \& Pharmaceutical Bulletin 2014, 37, 858-864.

141. Okuyama, E.; Gao, L.H.; Yamazaki, M. Analgesic components from bornean medicinal plants, Tabernaemontana pauciflora blume and Tabernaemontana pandacaqui poir. Chemical \&
Pharmaceutical Bulletin 1992, 40, 2075-2079.

142.Matsuda, H.; Wu, J.X.; Tanaka, T.; Iinuma, M.; Kubo, M. Antinociceptive activities of $70 \%$ methanol extract of evodiae fructus (fruit of Evodia rutaecarpa var. bodinieri) and its alkaloidal components. Biological \& Pharmaceutical Bulletin 1997, 20, 243248.

143.Zhao, D.; Shi, Y.; Zhu, X.; Liu, L.; Ji, P.; Long, C.; Shen, Y.; Kennelly, E.J. Identification of potential biomarkers from Aconitum carmichaelii, a traditional chinese medicine, using a metabolomic approach. Planta Medica 2017.

144.Suzuki, Y.; Oyama, T.; Ishige, A.; Isono, T.; Asami, A.; Ikeda, Y.; Noguchi, M.; Omiya, Y. Antinociceptive mechanism of the aconitine alkaloids mesaconitine and benzoylmesaconine. Planta Medica 1994, 60, 391-394.

145. Oyama, T.; Isono, T.; Suzuki, Y.; Hayakawa, Y. Antinociceptive effects of aconiti tuber and its alkaloids. American Journal of Chinese Medicine 1994, 22, 175-182.

146.Nesterova, Y.V.; Povet'Yeva, T.N.; Suslov, N.I.; Zyuz'Kov, G.N.; Pushkarskii, S.V.; Aksinenko, S.G.; Schultz, E.E.; Kravtsova, S.S.; Krapivin, A.V. Analgesic activity of diterpene alkaloids from Aconitum Baikalensis. Bulletin of Experimental Biology \& Medicine 2014, 157, 488-491.

147.Lin, Z.; Cai, W.; Tang, X. Anti-inflammatory and analgesic effects of yunaeonitine. Chinese Journal of Pharmacology and Toxicology 1987.

148. Gutser, U.T.; Friese, J.; Heubach, J.F.; Matthiesen, T.; Selve, N.; Wilffert, B.; Gleitz, J. Mode of antinociceptive and toxic action of alkaloids of Aconitum spec. Naunyn-Schmiedeberg's Archives of Pharmacology 1997, 357, 39-48.

149. Ono, M.; Satoh, T. Pharmacological studies of lappaconitine. Analgesia produced by intracerebroventricular, intracisternal and intrathecal injections. Journal of pharmacobio-dynamics 1990, 13, 374 .

150.Bello Ramirez, A.M.; Nava Ocampo, A. A. A QSAR analysis of toxicity of Aconitum alkaloids. Fundamental \& Clinical Pharmacology 2004, 18, 699-704.

151.Zhu, L.; Wu, J.; Zhao, M.; Song, W.; Qi, X.; Wang, Y.; Lu, L.; Liu, Z. Mdr1a plays a crucial role in regulating the analgesic effect and toxicity of aconitine by altering its pharmacokinetic characteristics. Toxicology \& Applied Pharmacology 2017, 320, 32-39.

152.Haiyan, W.; Yuxiang, L.; Linglu, D.; Tingting, X.; Yinju, H.; Hongyan, L.; Lin, M.; Yuanxu, J.; Yanrong, W.; Jianqiang, Y. Antinociceptive effects of matrine on neuropathic pain induced by chronic constriction injury. Pharmaceutical Biology 2013, 51, 844-850.

153.Linglu, D.; Yuxiang, L.; Yaqiong, X.; Ru, Z.; Lin, M.; Shaoju, J.; Juan, D.; Tao, S.; Jianqiang, Y. 
Antinociceptive effect of matrine on vincristineinduced neuropathic pain model in mice. Neurological Sciences Official Journal of the Italian Neurological Society \& of the Italian Society of Clinical Neurophysiology 2014, 35, 815-821.

154.Kamei, J.; Xiao, P.; Ohsawa, M.; Kubo, H.; Higashiyama, K.; Takahashi, H.; Li, J.; Nagase, H.; Ohmiya, S. Antinociceptive effects of $(+)$-matrine in mice. European Journal of Pharmacology 1997, 337, 223-226.

155. Menéndez, L.; Lastra, A.; Hidalgo, A.N.; Baamonde, A. The analgesic effect induced by capsaicin is enhanced in inflammatory states. Life Sciences 2004, 74, 3235-3244.

156. Ma, X.L.; Zhang, F.X.; Dong, F.; Bao, L.; Zhang, X. Experimental evidence for alleviating nociceptive hypersensitivity by single application of capsaicin. Molecular Pain 2015, 11, 22.

157.Chang, Z.Q.; Wang, S.L.; Hao, C.Y.; Liu, F.; Bian, C.F.; Chen, J.M. Analgesic, antispastic and sedative effects of skimmianine. Zhongguo Yao Li Xue Bao 1982, 3, 163-165.

158. Viswanathan, S.; Sambantham, P.T.; Reddy, K.; Kameswaran, L. Gossypin-induced analgesia in mice. Eur J Pharmacol 1984, 98, 289-291.

159.Déciga-Campos, M.; Mata, R.; Rivero-Cruz, I. Antinociceptive pharmacological profile of Dysphania graveolens in mouse. Biomedicine \& pharmacotherapy 2017, 89, 933.

160. Velázquez-González, C.; Cariño-Cortés, R.; Lucio, J.A.G.D.; Ortiz, M.I.; Arciniega, M.D.L.O.; Altamirano-Báez, D.A.; Jiménez-Ángeles, L.; Bautista-Ávila, M. Antinociceptive and antiinflammatory activities of Geranium bellum and its isolated compounds. Bmc Complementary \& Alternative Medicine 2014, 14, 506.

161.Kaur, R.; Singh, D.; Chopra, K. Participation of alpha2 receptors in the antinociceptive activity of quercetin. Journal of Medicinal Food 2005, 8, 529.

162. Calixtocampos, C.; Corrêa, M.P.; Carvalho, T.T.; Zarpelon, A.C.; Hohmann, M.S.N.; Rossaneis, A.C.; Coelhosilva, L.; Pavanelli, W.R.; Pingefilho, P.; Crespigio, J. Quercetin reduces ehrlich tumorinduced cancer pain in mice. Analytical Cellular Pathology,2015,(2015-8-13) 2015, 2015, 285708.

163. Anjaneyulu, M.; Chopra, K. Quercetin, a bioflavonoid, attenuates thermal hyperalgesia in a mouse model of diabetic neuropathic pain. Prog Neuropsychopharmacol Biol Psychiatry 2003, 27, 1001-1005.

164.Filho, A.W.; Filho, V.C.; Olinger, L.; de Souza, M.M. Quercetin: further investigation of its antinociceptive properties and mechanisms of action. Archives of Pharmacal Research 2008, 31, 713-721.

165. Guazelli, C.; Staurengoferrari, L.; Zarpelon, A.C.; Pinhoribeiro, F.A.; Ruizmiyazawa, K.W.; Vicentini, F.; Vignoli, J.A.; Camiliosneto, D.; Georgetti, S.R.;
Baracat, M.M. Quercetin attenuates zymosaninduced arthritis in mice. Biomedicine \& pharmacotherapy 2018, 102, 175.

166.Ruiz-Miyazawa, K.W.; Staurengo-Ferrari, L.; Mizokami, S.S.; Domiciano, T.P.; Vicentini, F.T.M.C.; Camilios-Neto, D.; Pavanelli, W.R.; Pinge-Filho, P.; Amaral, F.A.; Teixeira, M.M. Quercetin inhibits gout arthritis in mice: induction of an opioid-dependent regulation of inflammasome. Inflammopharmacology 2017, 1-16.

167.Hernandez-Leon, A.; Fernández-Guasti, A.; González-Trujano, M.E. Rutin antinociception involves opioidergic mechanism and descending modulation of ventrolateral periaqueductal grey matter in rats. European Journal of Pain 2016, 20, 274.

168.Alonso-Castro, A.J.; Isiordia-Espinoza, M.A.; Aragon-Martinez, O.H. Synergism between naproxen and rutin in a mouse model of visceral pain. Drug Development Research 2017, 78, 184.

169.Kim, S.H.; Park, J.G.; Sung, G.H.; Yang, S.; Yang, W.S.; Kim, E.; Kim, J.H.; Ha, V.T.; Kim, H.G.; Yi, Y.S. Kaempferol, a dietary flavonoid, ameliorates acute inflammatory and nociceptive symptoms in gastritis, pancreatitis, and abdominal pain. Molecular Nutrition \& Food Research 2015, 59, 1400.

170.Martínez, A.L.; González-Trujano, M.E.; Chávez, M.; Pellicer, F.; Moreno, J.; López-Muñoz, F.J. Hesperidin produces antinociceptive response and synergistic interaction with ketorolac in an arthritic gout-type pain in rats. Pharmacology Biochemistry \& Behavior 2011, 97, 683-689.

171.Carballo-Villalobos, A.I.; González-Trujano, M.E.; Pellicer, F.; López-Muñoz, F.J. Antihyperalgesic effect of hesperidin improves with diosmin in experimental neuropathic pain. Biomed Res Int 2016, 2016, 8263463 .

172.Banafshe, H.R.; Hamidi, G.A.; Noureddini, M.; Mirhashemi, S.M.; Mokhtari, R.; Shoferpour, M. Effect of curcumin on diabetic peripheral neuropathic pain: possible involvement of opioid system. European Journal of Pharmacology 2014, 723, 202206.

173.Nurullahoglu, K.E.; Okudan, N.; Belviranli, M.; Oz, $\mathrm{M}$. The comparison of preemptive analgesic effects of curcumin and diclofenac. Bratisl Lek Listy 2014, $115,757-760$.

174. Sahbaie, P.; Sun, Y.; Liang, D.Y.; Shi, X.Y.; Clark, J.D. Curcumin treatment attenuates pain and enhances functional recovery after incision. Anesthesia \& Analgesia 2014, 118, 1336-1344.

175.Córdova, M.M.; Werner, M.F.D.P.; Silva, M.D.D.; Ruani, A.P.; Pizzolatti, M.G.; Santos, A.R.S. Further antinociceptive effects of myricitrin in chemical models of overt nociception in mice. Neuroscience Letters 2011, 495, 173-177.

176.Meotti, F.C.; Missau, F.C.; Ferreira, J.; Pizzolatti, 
M.G.; Mizuzaki, C.; Nogueira, C.W.; Santos, A.R. Anti-allodynic property of flavonoid myricitrin in models of persistent inflammatory and neuropathic pain in mice. Biochemical Pharmacology 2006, 72, 1707-1713.

177. Santos, F.A.; Rao, V.S. Antiinflammatory and antinociceptive effects of 1,8-cineole a terpenoid oxide present in many plant essential oils. Phytotherapy Research Ptr 2000, 14, 240.

178. Almeida, J.R.; Souza, G.R.; Silva, J.C.; Saraiva, S.R.; Quintans, J.S.; Barreto, R.S.; Bonjardim, L.R.; Cavalcanti, S.C.; Jr, Q.L. Borneol, a bicyclic monoterpene alcohol, reduces nociceptive behavior and inflammatory response in mice. Thescientificworldjournal 2013, 2013, 808460.

179. Jaishree, V.; Badami, S.; Rupesh, K.M.; Tamizhmani, T. Antinociceptive activity of swertiamarin isolated from Enicostemma axillare. Phytomedicine 2009, 16, 227-232.

180.Heesung, C.; Kang, O.H.; Youngseob, L.; Janggi, C.; Youchang, O.; Hyejin, J.; Minsan, K.; Jonghak, K.; Seungil, J.; Dongyeul, K. Inhibition of LPS-induced iNOS, COX-2 and inflammatory mediator expression by paeonol through the mapks inactivation in RAW 264.7 cells. American Journal of Chinese Medicine 2009, 37, 181.

181.Chou, T.C.; Chang, L.P.; Li, C.Y.; Wong, C.S.; Yang, S.P. The antiinflammatory and analgesic effects of baicalin in carrageenan-evoked thermal hyperalgesia. British Journal of Pharmacology 2003, 139, 17241729.

182. Okuyama, E.; Hasegawa, T.; Matsushita, T.; Fujimoto, H.; Ishibashi, M.; Yamazaki, M. Analgesic components of Saposhnikovia root (Saposhnikovia divaricata). Chemical \& Pharmacentical Bulletin 2001, 49, 154-160.

183.Ma, Y.; Li, C.; Li, L.; Zhao, B.; Guo, S.; Huo, H. Experimental study on antipyretic, analgesic and anti-inflammatory actions of cinnamaldehyde. Chinese Journal of Clinical Pharmacology and Therapeutics, 2006, 11, 1336-1339.

184. Okuyama, E.; Nishimura, S.; Ohmori, S.; Ozaki, Y.; Satake, M.; Yamazaki, M. Analgesic component of Notopterygium incisum Ting. Chemical \& Pharmaceutical Bulletin 1993, 41, 926.

185. Barros, T.A.; de Freitas, L.A.; Filho, J.M.; Nunes, X.P.; Giulietti, A.M.; de Souza, G.E.; dos Santos, R.R.; Soares, M.B.; Villarreal, C.F. Antinociceptive and anti-inflammatory properties of 7 hydroxycoumarin in experimental animal models: potential therapeutic for the control of inflammatory chronic pain. Journal of Pharmacy \& Pharmacology 2010, 62, 205-213.

186. Singh, G.; Bhatti, R.; Mannan, R.; Singh, D.; Kesavan, A.; Singh, P. Osthole ameliorates neurogenic and inflammatory hyperalgesia by modulation of iNOS, COX-2, and inflammatory cytokines in mice. 2018

187. Shakya, A.; Singh, G.K.; Chatterjee, S.S.; Kumar, V. Role of fumaric acid in anti-inflammatory and analgesic activities of a Fumaria indica extracts. Journal of Intercultural Ethnopharmacology 2014, 3, 173-178.

188.Jung, H.J.; Park, H.J.; Kim, R.G.; Shin, K.M.; Ha, J.; Choi, J.W.; Kim, H.J.; Lee, Y.S.; Lee, K.T. In vivo anti-inflammatory and antinociceptive effects of liriodendrin isolated from the stem bark of Acanthopanax senticosus. Planta Med 2003, 69, 610616. 
J Pharm Pharm Sci (www.cspsCanada.org) 21, 437 - 480, 2018

\begin{tabular}{|c|c|c|c|c|c|c|c|c|}
\hline No. & Compounds & CAS & $\begin{array}{l}\text { Molecular } \\
\text { formula }\end{array}$ & Sources $^{1}$ & Latin name ${ }^{2}$ & Family & Medical Part ${ }^{3}$ & Ref \\
\hline & Alkaloids & & & & & & & \\
\hline \multirow[t]{2}{*}{1} & Trilobine & $6138-73-4$ & $\mathrm{C}_{35} \mathrm{H}_{34} \mathrm{~N}_{2} \mathrm{O}_{5}$ & Baiyaozi & Stephania cepharantha & Menispermaceae & Root tubers & [81] \\
\hline & & & & Mufangji & Cocculus orbiculatus & Menispermaceae & Roots & {$[81$} \\
\hline \multirow[t]{14}{*}{2} & Palmatine & $3486-67-7$ & $\mathrm{C}_{21} \mathrm{H}_{22} \mathrm{NO}_{4}^{+}$ & Banruitangsongcao & Thalictrum petaloideum & Ranunculaceae & Roost and rhizomes & [91] \\
\hline & & & & Yanguocao & Thalictrum minus & Ranunculaceae & Roots and rhizomes & [91] \\
\hline & & & & Huangbai & Phellodendron amurense & Rutaceae & Barks & [91] \\
\hline & & & & Huanglian & Coptis chinensis & Ranunculaceae & Rhizomes & [91] \\
\hline & & & & Haisongzi & Pinus koraiensis & Pinaceae & Seeds & [91] \\
\hline & & & & Maweilian & Thalictrum foliolosum & Ranunculaceae & Roots and rhizomes & [91] \\
\hline & & & & Shidagonglaogen & Mahonia japonica & Berberidaceae & Roots & [91] \\
\hline & & & & Shidagonglaoye & Mahonia fortune & Berberidaceae & leaves & [91] \\
\hline & & & & Xiatianwu & Corydalis decumbens & Papaveraceae & Tubers & [91] \\
\hline & & & & Xiaobo & Berberis silvataroucan & Berberidaceae & Roots/stems/branches & [91] \\
\hline & & & & Huanglian & Coptis teetoides & Ranunculaceae & Rhizomes & [91] \\
\hline & & & & Yanhusuo & Corydalis yanhusuo & Papaveraceae & Tubers & [91] \\
\hline & & & & Alishanshidagonglao & Mahonia oiwakensis & Berberidaceae & Stems & {$[-92]$} \\
\hline & & & & Qingniudan & Tinospora sagittata & Berberidaceae & Roots & [93] \\
\hline \multirow[t]{6}{*}{3} & Tetrandrine & $2086-83-1$ & $\mathrm{C}_{20} \mathrm{H}_{18} \mathrm{~N}_{2} \mathrm{O}_{4}^{+}$ & Baiyaozi & Stephania cepharantha & Menispermaceae & Root tubers & [91] \\
\hline & & & & Bianfugegen & Menispermum & Menispermaceae & Rhizomes & {$[-91]$} \\
\hline & & & & Fenfangji & Stephania tetrandra & Menispermaceae & Tubers & {$[-91]$} \\
\hline & & & & Yinbuhuan & Cyclea barbata & Menispermaceae & Roots and stems & {$[-91]$} \\
\hline & & & & Hangfangji & Aristolochia heterophylla & Menispermaceae & Tubers & {$[-91]$} \\
\hline & & & & Qingmuxiang & Aristolochia debilis & Aristolochiaceae & Roots & {$[-91]$} \\
\hline \multirow[t]{2}{*}{4} & Berberine & $2086-83-1$ & $\mathrm{C}_{20} \mathrm{H}_{18} \mathrm{~N}_{2} \mathrm{O}_{4}^{+}$ & Baiqucai & Chelidonium majus & Papaveraceae & Whole grass & [94] \\
\hline & & & & Baiyaozi & Stephania cepharantha & Menispermaceae & Root tubers & {$[-94]$} \\
\hline
\end{tabular}


J Pharm Pharm Sci (www.cspsCanada.org) 21, 437 - 480, 2018

\begin{tabular}{|c|c|c|c|c|c|c|c|c|}
\hline & & & & Banruitangsongcao & Thalictrum petaloideum & Ranunculaceae & Roots and rhizomes & {$[-94]$} \\
\hline & & & & Huangbai & Phellodendron amurense & Rutaceae & Barks & {$[-94]$} \\
\hline & & & & Huanglian & Coptis chinensis & Ranunculaceae & Rhizomes & {$[-94]$} \\
\hline & & & & Maweilian & Thalictrum foliolosum & Ranunculaceae & Roots and rhizomes & [94] \\
\hline & & & & Yanguocao & Thalictrum minus & Ranunculaceae & Roots and rhizomes & {$[94]$} \\
\hline & & & & Yanhusuo & Corydalis yanhusuo & Papaveraceae & Tubers & {$[-94]$} \\
\hline & & & & Kuoyeshidagonglao & Mahonia bealei & Berberidaceae & Roots & {$[-94]$} \\
\hline & & & & Huananshidagonglao & Mahonia japonica & Berberidaceae & Roots & {$[-94]$} \\
\hline 5 & Rhoifoline A & & $\mathrm{C}_{20} \mathrm{H}_{13} \mathrm{NO}_{5}$ & Liangmianzhen & Zanthoxylum nitidum & Rutaceae & Roots/Root barks & {$[41]$} \\
\hline \multirow[t]{2}{*}{6} & Dicentrine & $517-66-8$ & $\mathrm{C}_{20} \mathrm{H}_{21} \mathrm{NO}_{4}$ & Wugenteng & Cassytha filiformis & Lauraceae & Whole grass & {$[-95]$} \\
\hline & & & & Heikenan & Lindera megaphylla & Lauraceae & Roots/barks/branches & [96] \\
\hline 7 & Govaniadine & & $\mathrm{C}_{24} \mathrm{H}_{37} \mathrm{NO}_{6}$ & Kumanghuangjin & Corydalis govaniana & Papaveraceae & Whole grass & {$[19]$} \\
\hline \multirow[t]{2}{*}{8} & Sinomenine & $115-53-7$ & $\mathrm{C}_{19} \mathrm{H}_{23} \mathrm{NO}_{4}$ & Bianfugegen & Menispermum dauricum & Menispermaceae & Rhizomes & {$[-94]$} \\
\hline & & & & Qingfengteng & Sinomenium aeutum & Menispermaceae & Stems & {$[-94]$} \\
\hline \multirow[t]{5}{*}{9} & Tetrahydropalmatine & $2934-97-6$ & $\mathrm{C}_{21} \mathrm{H}_{25} \mathrm{NO}_{4}$ & Yanhusuo & Corydalis yanhusuo & Papaveraceae & Tubers & {$[-81]$} \\
\hline & & & & Xiatianwu & Corydalis decumbens & Papaveraceae & Tubers & {$[81]$} \\
\hline & & & & Juhuahuanglian & Corydalis pallida & Papaveraceae & Roots & {$[81]$} \\
\hline & & & & - & - & - & - & - \\
\hline & & & & Chibanyanhusuo & Corydalis remota & Papaveraceae & Tubers & {$[-91]$} \\
\hline 10 & Gelsemine & $509-15-9$ & $\mathrm{C}_{20} \mathrm{H}_{22} \mathrm{~N}_{2} \mathrm{O}_{2}$ & Gouwen & Gelsemium elegans & Loganiaceae & Whole plant & {$[-52]$} \\
\hline \multirow[t]{2}{*}{11} & Coronaridine & $2752-64-9$ & $\mathrm{C}_{33} \mathrm{H}_{45} \mathrm{NO}_{11}$ & Changchunhua & Catharanthus roseus & Apocynaceae & Whole grass & {$[-81]$} \\
\hline & & & & Gouyahua & Ervatamia divaricata & Apocynaceae & Roots and leaves & {$[-81]$} \\
\hline \multirow[t]{2}{*}{12} & Rutaecarpine & $84-26-4$ & $\mathrm{C}_{18} \mathrm{H}_{13} \mathrm{~N}_{3} \mathrm{O}$ & Wuzhuyu & Evodia rutaecarpa & Rutaceae & Immature fruits & {$[-81]$} \\
\hline & & & & Shihu & Evodia rutaecarpa & Rutaceae & Immature fruits & {$[81]$} \\
\hline 13 & Mitragynine & $4098-40-2$ & $\mathrm{C}_{23} \mathrm{H}_{30} \mathrm{~N}_{2} \mathrm{O}_{4}$ & Meilimaozhumu & Mitragyna speciosa & Rubiaceae & Leaves & {$[-98]$} \\
\hline 14 & Harmine & $442-51-3$ & $\mathrm{C}_{13} \mathrm{H}_{12} \mathrm{~N}_{2} \mathrm{O}$ & Luotuopeng & Peganum harmala & Zygophyllaceae & Whole grass & {$[-99]$} \\
\hline 15 & $(3 S, 4 S, 15 S, 20 R)-$ & & $\mathrm{C}_{19} \mathrm{H}_{24} \mathrm{~N}_{2} \mathrm{O}_{2}$ & Niuyanmaqian & Strychnos angustiflora & Loganiaceae & Seeds & {$[-100]$} \\
\hline
\end{tabular}


J Pharm Pharm Sci (www.cspsCanada.org) 21, 437 - 480, 2018

antirhine $\mathrm{N}_{4}$-oxide

17 Alangine

18 Antirhine

19 Harmane

20 Norharmane

21 Mesaconitine

23

16 21-O-syringoylantirhne

Yunaconitine

$518-34-3$

$\mathrm{C}_{38} \mathrm{H}_{42} \mathrm{~N}_{2} \mathrm{O}_{6}$

Lappaconitine

32854-75-4

$\mathrm{C}_{32} \mathrm{H}_{44} \mathrm{~N}_{2} \mathrm{O}_{8}$

Bullatine A

1354-84-3

Aconitine

302-27-2

$\mathrm{C}_{22} \mathrm{H}_{33} \mathrm{NO}_{2}$

$\mathrm{C}_{34} \mathrm{H}_{47} \mathrm{NO}_{11}$

$\mathrm{C}_{28} \mathrm{H}_{32} \mathrm{~N}_{2} \mathrm{O}_{5} \quad$ Niuyanmaqian

$\mathrm{C}_{19} \mathrm{H}_{27} \mathrm{NO}_{2} \quad$ Niuyanmaqian

$\mathrm{C}_{19} \mathrm{H}_{24} \mathrm{~N}_{2} \mathrm{O}$ Niuyanmaqian

$\mathrm{C}_{12} \mathrm{H}_{10} \mathrm{~N}_{2} \quad$ Luotuopeng

$\mathrm{C}_{11} \mathrm{H}_{8} \mathrm{~N}_{2} \quad$ Luotuopeng

$\mathrm{C}_{35} \mathrm{H}_{49} \mathrm{NO}_{11}$

Fuzi

Beiwutou

Wutou

Beiwutou

Dianxiwutou

Dongchuanwutou

Huangcaowu

Ganwanwutou

Gaowutou

Niubian

Xueshangyizhihao

Wutou

Beiwutou

Fuzi

Xueshangyizhihao

Guiwuline

1358-76-5

$\mathrm{C}_{20} \mathrm{H}_{22} \mathrm{~N}_{2} \mathrm{O}$

Wutou

Incarvillateine

129748-10-3

8-O-ethylaconosine

Aconicarmisulfonine A

Oxymatrine

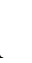

6837-52-8
$\mathrm{C}_{15} \mathrm{H}_{24} \mathrm{~N}_{2} \mathrm{O}_{2} \quad$ Baicihua

\section{$\mathrm{C}_{42} \mathrm{H}_{58} \mathrm{~N}_{2} \mathrm{O}_{8} \quad$ Jiaohao \\ $\mathrm{C}_{24} \mathrm{H}_{39} \mathrm{NO}_{4}$ \\ Weixiwutou \\ $\mathrm{C}_{22} \mathrm{H}_{29} \mathrm{NO}_{6} \mathrm{~S} \quad$ Wutou}

Strychnos angustiflora

Strychnos angustiflora

Strychnos angustiflora

Peganum harmala

Peganum harmala

Aconitum carmichaeli

Aconitum kusnezoffii

Aconitum carmichaeli

Aconitum kusnezoffii

Aconitum bulleyanum

Aconitum geniculatum

Aconitum vilmorinianum

Aconitum finetianum

Aconitum sinomontanum

Aconitum barbatum

Aconitum brachypodum

Aconitum carmichaeli

Aconitum kusnezoffii

Aconitum carmichaeli

Aconitum brachypodum

Aconitum carmichaeli

Incarvillea sinensis

Aconitum weixiense

Aconitum carmichaelii

Sophora davidii

Sophora alopecuroides

Sophora flavescens

$\begin{array}{ll}\text { Loganiaceae } & \text { Seeds } \\ \text { Loganiaceae } & \text { Seeds } \\ \text { Loganiaceae } & \text { Seeds } \\ \text { Zygophyllaceae } & \text { Whole grass } \\ \text { Zygophyllaceae } & \text { Whole grass } \\ \text { Ranunculaceae } & \text { Daughter roots } \\ \text { Ranunculaceae } & \text { Root tubers } \\ \text { Ranunculaceae } & \text { Root tubers } \\ \text { Ranunculaceae } & \text { Root tubers } \\ \text { Ranunculaceae } & \text { Roots } \\ \text { Ranunculaceae } & \text { Root tubers } \\ \text { Ranunculaceae } & \text { Root tubers } \\ \text { Ranunculaceae } & \text { Tubers } \\ \text { Ranunculaceae } & \text { Roots } \\ \text { Ranunculaceae } & \text { Roots } \\ \text { Ranunculaceae } & \text { Roots } \\ \text { Ranunculaceae } & \text { Root tubers } \\ \text { Ranunculaceae } & \text { Root tubers } \\ \text { Ranunculaceae } & \text { Roots } \\ \text { Ranunculaceae } & \text { Roots } \\ \text { Ranunculaceae } & \text { Root tubers } \\ \text { Bignoniaceae } & \text { Aerial part } \\ \text { Ranunculaceae } & \text { Roots } \\ \text { Ranunculaceae } & \text { Roots } \\ \text { Leguminosae } & \text { Flowers } \\ \text { Leguminosae } & \text { Seeds } \\ \text { Leguminosae } & \text { Roots } \\ & \end{array}$

[100]

[-100]

[-100]

[-99]

[-99]

[-81]

[-94]

[-94]

[101]

[101]

[101]

[102] 
J Pharm Pharm Sci (www.cspsCanada.org) 21, 437 - 480, 2018

\begin{tabular}{|c|c|c|c|c|c|c|c|c|}
\hline & & & & Shashenhuai & Sophora moorcroftiana & Leguminosae & Seeds & {$[-81]$} \\
\hline & & & & Shandougen & Sophora subprostrata & Leguminosae & Roots & {$[-81]$} \\
\hline \multirow[t]{2}{*}{31} & $(-)$-Spectaline & $96614-54-9$ & $\mathrm{C}_{20} \mathrm{H}_{39} \mathrm{NO}_{2}$ & Xiayejueming & Cassia leptophylla & Leguminosae & Flowers & {$[-106]$} \\
\hline & & & & Meilijueming & Cassia spectabilis & Leguminosae & Seeds & [107] \\
\hline 32 & Huperzine A & $102518-79-6$ & $\mathrm{C}_{15} \mathrm{H}_{18} \mathrm{~N}_{2} \mathrm{O}$ & Shezushisha & Huperzia serrata & Huperziaceae & Whole grass & {$[27]$} \\
\hline \multirow[t]{4}{*}{33} & Matrine & $519-02-8$ & $\mathrm{C}_{15} \mathrm{H}_{24} \mathrm{~N}_{2} \mathrm{O}$ & Baicihua & Sophora davidii & Leguminosae & Flowers & {$[-81]$} \\
\hline & & & & Kudouzi & Sophora alopecuroides & Leguminosae & Seeds & [81] \\
\hline & & & & Kushen & Sophora flavescens & Leguminosae & Roots & {$[81]$} \\
\hline & & & & Shandougen & Sophora subprostrata & Leguminosae & Roots & [81] \\
\hline 34 & Capsaicin & $404-86-4$ & $\mathrm{C}_{18} \mathrm{H}_{27} \mathrm{NO}_{3}$ & Lajiao & Capsicum annuum & Solanaceae & Fruits & [91] \\
\hline 35 & Scotanamine B & & $\mathrm{C}_{26} \mathrm{H}_{37} \mathrm{~N}_{3} \mathrm{O}_{7}$ & Shanlangdanag & Scopolia tangutica & Solanaceae & Roots & {$[20]$} \\
\hline \multirow[t]{6}{*}{36} & Skimmianine & $83-95-4$ & $\mathrm{C}_{14} \mathrm{H}_{13} \mathrm{NO}_{4}$ & Baixianpi & Dictamnus dasycarpus & Rutaceae & Root barks & [91] \\
\hline & & & & Choucao & Ruta guaveolens & Rutaceae & Whole grass & {$[91]$} \\
\hline & & & & Feilongzhangxue & Toddalia asiatica & Rutaceae & Roots or root barks & [91] \\
\hline & & & & Gouju & Poncirus tuifoliata & Rutaceae & Young fruits & {$[91]$} \\
\hline & & & & Huajiao & Zanthoxylum bungeanum & Rutaceae & Peels & [91] \\
\hline & & & & Yinyu & Skimmia reevesiana & Rutaceae & Stems and leaves & {$[91]$} \\
\hline 37 & Veratraline A & & $\mathrm{C}_{30} \mathrm{H}_{45} \mathrm{~N}_{2} \mathrm{O}_{2}$ & Dalililu & Veratrum taliense & Liliaceae & Roots and rhizomes & {$[108]$} \\
\hline 38 & Veratraline B & & $\mathrm{C}_{27} \mathrm{H}_{42} \mathrm{NO}_{4}$ & Dalililu & Veratrum taliense & Liliaceae & Roots and rhizomes & {$[=108]$} \\
\hline 39 & Veratraline $\mathrm{C}$ & & $\mathrm{C}_{27} \mathrm{H}_{42} \mathrm{NO}_{4}$ & Dalililu & Veratrum taliense & Liliaceae & Roots and rhizomes & {$[-108]$} \\
\hline 40 & Isomurrayafoline B & $107903-15-1$ & $\mathrm{C}_{19} \mathrm{H}_{21} \mathrm{NO}_{2}$ & Qianlixiang & Murraya paniculata & Rutaceae & Leaves & {$[109]$} \\
\hline \multicolumn{9}{|c|}{ Flavonoids } \\
\hline 41 & Gossypin & $652-78-8$ & $\mathrm{C}_{21} \mathrm{H}_{20} \mathrm{O}_{13}$ & Mopancao & Abutilon indicum & Malvaceae & Whole grass & 158 \\
\hline \multirow[t]{5}{*}{42} & Hyperin & $482-36-0$ & $\mathrm{C}_{21} \mathrm{H}_{20} \mathrm{O}_{12}$ & Biandijin & Hypericum wightianum & Guttiferae & Whole grass & {$[-94]$} \\
\hline & & & & Gouteng & Uncaria rhynchophylla & Rubiaceae & Branches & {$[=94]$} \\
\hline & & & & Jinsimei & Hypericum patulum & Guttiferae & Whole grass & {$[-94]$} \\
\hline & & & & Laoguancao & Erodium stephanianum & Geraniaceae & Whole grass & {$[=94]$} \\
\hline & & & & Luxiancao & Pyrola calliantha & Pyrolaceae & Whole grass & {$[-94]$} \\
\hline
\end{tabular}


J Pharm Pharm Sci (www.cspsCanada.org) 21, 437 - 480, 2018

\begin{tabular}{|c|c|c|c|c|c|c|c|c|}
\hline & & & & Manshanhong & Folium Rhododendri & Ericaceae & Leaves & {$[-94]$} \\
\hline & & & & Luobuma & Apocynum venetum & Apocynaceae & Leaves & {$[-94]$} \\
\hline & & & & Maoyancao & Euphorbia lunulata & Euphorbiaceae & Whole grass & {$[-94]$} \\
\hline & & & & Tusizi & Cuscuta chinensis & Convolvulaceae & Seeds & {$[-94]$} \\
\hline & & & & Xiakucao & Prunella vulgaris & Labiatae & Ear & {$[-94]$} \\
\hline & & & & Xianhecao & Agrimonia pilosa & Rosaceae & Aerial part & {$[-94]$} \\
\hline & & & & Yinchenhao & Artemisia capillaris & compositae & Aerial part & {$[-94]$} \\
\hline & & & & Yuxingcao & Houttuynia cordata & saururaceae & Aerial part & {$[-94]$} \\
\hline & & & & Yuanbaocao & Hypericum sampsonii & Guttiferae & Whole grass & {$[-94]$} \\
\hline \multirow[t]{2}{*}{43} & Chrysin & $480-40-0$ & $\mathrm{C}_{15} \mathrm{H}_{10} \mathrm{O}_{4}$ & Tuorongweilingcai & Potentilla evestita & Rosaceae & Whole grass & {$[-110]$} \\
\hline & & & & Xifanlian & Passiflora coerulea & Passifloraceae & Whole grass & {$[38]$} \\
\hline 44 & Lycopene & $502-65-8$ & $\mathrm{C}_{40} \mathrm{H}_{56}$ & Fanqie & Lycopersicon esculentum & Solanaceae & Fruits & {$[-86]$} \\
\hline \multirow[t]{3}{*}{45} & Eupatilin & $22368-21-4$ & $\mathrm{C}_{18} \mathrm{H}_{16} \mathrm{O}_{7}$ & Aiye & Artemisia argyi & Compositae & Leaves & {$[81]$} \\
\hline & & & & Qihao & Artemisia anomala & Compositae & Whole grass & {$[81]$} \\
\hline & & & & Kuihao & Artemisia princeps & Compositae & Whole grass & [111] \\
\hline \multirow[t]{2}{*}{46} & Acacetin & $480-44-4$ & $\mathrm{C}_{16} \mathrm{H}_{12} \mathrm{O}_{5}$ & Fengchaocao & Leucas aspera & Labiatae & Whole grass & {$[34]$} \\
\hline & & & & Tuorongweilingcao & Potentilla evestita & Rosaceae & Whole grass & {$[112]$} \\
\hline \multirow[t]{2}{*}{47} & Ellagic acid & $476-66-4$ & $\mathrm{C}_{14} \mathrm{H}_{6} \mathrm{O}_{8}$ & Shiliu & Punica granatum & Punicaceae & Peels & {$[88]$} \\
\hline & & & & Caomei & Fragaria $\times$ ananassa & Rosaceae & Fruits & {$[-88]$} \\
\hline \multirow[t]{9}{*}{48} & Quercetin & $117-39-5$ & $\mathrm{C}_{15} \mathrm{H}_{10} \mathrm{O}_{7}$ & Chuanbajiaolian & Dysosma veitchii & Berberidaceae & Whole grass & {$[17]$} \\
\hline & & & & Huanghaitang & Hypericum ascyron & Guttiferae & Whole grass & {$[17]$} \\
\hline & & & & Huaihua & Sophora japonica & Leguminosae & Flowers & {$[17]$} \\
\hline & & & & Huaimi & Sophora japonica & Leguminosae & Flower buds & {$[17]$} \\
\hline & & & & Danpi & Paeonia suffruticosa & Ranunculaceae & Root bark & {$[17]$} \\
\hline & & & & Juhua & Dendranthema morifolium & Compositae & Flowers & {$[17]$} \\
\hline & & & & Tianjihuang & Hypericum japonicum & Guttiferae & Whole grass & {$[17]$} \\
\hline & & & & Cheqianzi & Plantago asiatica & Plantaginaceae & Seeds & {$[17]$} \\
\hline & & & & Sangjisheng & Taxillus sutchuenensis & Loranthaceae & Branch leaves & {$[17]$} \\
\hline
\end{tabular}


J Pharm Pharm Sci (www.cspsCanada.org) 21, 437 - 480, 2018

\begin{tabular}{|c|c|c|c|c|c|c|c|c|c|}
\hline & & & & & Xianhecao & Agrimonia pilosa & Rosaceae & Aerial part & [17] \\
\hline & & & & & Jiaogulan & Gynostemma pentaphyllum & Cucurbitaceae & Whole grass & {$[17]$} \\
\hline & & & & & Shanzha & Crataegus pinnatifida & Rosaceae & Fruits & {$[17]$} \\
\hline & & & & & Guanyelianqiao & Hypericum perforatum & Guttiferae & Whole grass & {$[17]$} \\
\hline & & & & & Tusizi & Cuscuta chinensis & Convolvulaceae & Seeds & [17] \\
\hline & & & & & Ciwujia & Acanthopanax senticosus & Araliaceae & Root bark & {$[17]$} \\
\hline & & & & & Jiguanhua & Celosia cristata & Amaranthaceae & Inflorescence & {$[17]$} \\
\hline & & & & & Yuxingcao & Houttuynia cordata & Saururaceae & Whole grass & {$[17]$} \\
\hline & & & & & Yuganzi & Phyllanthus emblica & Euphorbiaceae & Fruits & {$[17]$} \\
\hline & & & & & Sanbaicao & Saururus chinensis & Saururaceae & Aerial part & {$[17]$} \\
\hline & & & & & Chuipencao & Sedum sarmentosum & Crassulaceae & Whole grass & {$[17]$} \\
\hline \multirow[t]{3}{*}{49} & Rutin & & $153-18-4$ & $\mathrm{C}_{27} \mathrm{H}_{30} \mathrm{O}_{16}$ & Huaimi & Sophora japonica & Leguminosae & Flower buds & {$[-81]$} \\
\hline & & & & & Kuqiaomai & Fagopyrum tataricum & Polygonaceae & Seeds & {$[-81]$} \\
\hline & & & & & Pugongying & Taraxacum mongolicum & Compositae & Whole grass & {$[-81]$} \\
\hline \multirow[t]{2}{*}{50} & Kaempferol & & $520-18-3$ & $\mathrm{C}_{15} \mathrm{H}_{10} \mathrm{O}_{6}$ & Xiyangjiegumu & Sambucus nigra & Caprifoliaceae & Inflorescence & {$[113]$} \\
\hline & & & & & Bairuicai & Thesium chinense & Santalaceae & Whole grass & [114] \\
\hline 51 & $\begin{array}{l}\text { Hesperidin } \\
\text { chalcone }\end{array}$ & methyl & $24292-52-2$ & $\mathrm{C}_{29} \mathrm{H}_{36} \mathrm{O}_{15}$ & Chenzi & Citrus junos & Rutaceae & Fruits & {$[62]$} \\
\hline \multirow[t]{5}{*}{52} & Hesperidin & & $520-26-3$ & $\mathrm{C}_{28} \mathrm{H}_{34} \mathrm{O}_{15}$ & Qingpi & Citrus reticulate & Rutaceae & Young fruits or peels & {$[81]$} \\
\hline & & & & & Zhishi & Citrus aura & Rutaceae & Young fruits & {$[81]$} \\
\hline & & & & & Chenzipi & Citrus junos & Rutaceae & Peels & {$[81]$} \\
\hline & & & & & Chenzi & Citrus junos & Rutaceae & Fruits & {$[81]$} \\
\hline & & & & & Midiexiang & Rosmarinus officinalis & Labiatae & Whole grass & {$[81]$} \\
\hline \multirow[t]{3}{*}{53} & Curcumin & & $458-37-7$ & $\mathrm{C}_{21} \mathrm{H}_{20} \mathrm{O}_{6}$ & Jianghuang & Curcuma longa & Zingiberaceae & Rhizomes & {$[81]$} \\
\hline & & & & & Yujin & Curcuma wenyujin & Zingiberaceae & Root tubers & {$[81]$} \\
\hline & & & & & Ezhu & Curcuma aeruginosa & Zingiberaceae & Rhizomes & {$[81]$} \\
\hline
\end{tabular}


J Pharm Pharm Sci (www.cspsCanada.org) 21, 437 - 480, 2018

\begin{tabular}{|c|c|c|c|c|c|c|c|c|}
\hline 54 & $\begin{array}{l}\text { Kempferol-3,4'-di-O- } \\
\alpha \text {-L- } \\
\text { rhamnopyranoside }\end{array}$ & & $\mathrm{C}_{27} \mathrm{H}_{30} \mathrm{O}_{14}$ & Suoluolinmaojue & Dryopteris cycadina & Dryopteridaceae & Rhizomes & [115] \\
\hline \multirow[t]{2}{*}{55} & Myricitrin & $17912-87-7$ & $\mathrm{C}_{21} \mathrm{H}_{20} \mathrm{O}_{12}$ & Renxinguo & Manilkara zapota & Sapotaceae & Fruits & [116] \\
\hline & & & & Hongguozi & Eugenia uniflora & Myrtaceae & Leaves & {$[116]$} \\
\hline \multicolumn{9}{|c|}{ Terpenes } \\
\hline \multirow[t]{14}{*}{56} & 1,8-Cineole & $470-82-6$ & $\mathrm{C}_{10} \mathrm{H}_{18} \mathrm{O}$ & Donglingcao & Rabdosia rubescens & Labiatae & Whole grass & {$[94]$} \\
\hline & & & & Ganjiang & Zingiber officinale & Zingiberaceae & Dryingrhizomes & [94] \\
\hline & & & & Huajiao & Zanthoxylum bungeanum & Rutaceae & Peels & {$[94]$} \\
\hline & & & & Qinghao & Artemisia annua & Compositae & Whole grass & {$[94]$} \\
\hline & & & & Shengjiang & Zingiber officinale & Zingiberaceae & FreshRhizomes & [94] \\
\hline & & & & Xixin & Asarum sieboldii & Aristolochiaceae & Whole grass & {$[94]$} \\
\hline & & & & Liaoxixin & Asarum heterotropoides & Aristolochiaceae & Whole grass & {$[94]$} \\
\hline & & & & Manjingzi & Vitex trifolia & Verbenaceae & Fruits & {$[94]$} \\
\hline & & & & Zhizhuxiang & Valeriana jatamansii & Valerianaceae & Rhizomes & [94] \\
\hline & & & & Baidoukou & Amomun kravanh & Zingiberaceae & Mature fruits & {$[94]$} \\
\hline & & & & Zhaowabaidoukou & Amonum compactum & Zingiberaceae & Mature fruits & {$[94]$} \\
\hline & & & & Yangshicao & Achillea millefolium & Compositae & Whole grass & [94] \\
\hline & & & & Dayezizhu & Callicarpa macrophylla & Verbenaceae & Root or leaves & [117] \\
\hline & & & & Xiaodoukou & Elettaria cardamomum & Zingiberaceae & Seeds & [118] \\
\hline \multirow[t]{8}{*}{57} & $p$-Cymene & $99-87-6$ & $\mathrm{C}_{10} \mathrm{H}_{14}$ & Donglingcao & Rabdosia rubescens & Labiatae & Whole grass & {$[81]$} \\
\hline & & & & Dusong & Juniperus rigida & Cupressaceae & Branch leavescone & {$[81]$} \\
\hline & & & & Ganjiang & Zingiber officinale & Zingiberaceae & Dryingrhizomes & {$[81]$} \\
\hline & & & & Gangsong & Baeckea frutescens & Myrtaceae & Branch leaves & {$[81]$} \\
\hline & & & & Duhuo & Angelica pubescens & Umbelliferae & Roots & {$[81]$} \\
\hline & & & & Houpu & Magnolia officinalis & Magnoliaceae & Barks and roots & {$[81]$} \\
\hline & & & & Xixin & Asarum sieboldii & Aristolochiaceae & Whole grass & {$[81]$} \\
\hline & & & & Liaoxixin & Liaoxixin & Aristolochiaceae & Whole grass & [81] \\
\hline
\end{tabular}


J Pharm Pharm Sci (www.cspsCanada.org) 21, 437 - 480, 2018

\begin{tabular}{|c|c|c|c|c|c|c|c|c|}
\hline & & & & Shengjiang & Zingiber officinale & Zingiberaceae & FreshRhizome & [81] \\
\hline & & & & Yinchenhao & Artemisia capillaris & Compositae & Aerial part & [81] \\
\hline & & & & Wusemei & Lantana camara & Verbenaceae & Flowers & [81] \\
\hline & & & & Kuanyeqianghuo & Notopterygium forbesii & Umbelliferae & Root and rhizomes & [81] \\
\hline & & & & Baishantai & Ledum palustre & Ericaceae & Leaves & [81] \\
\hline & & & & Baidoukou & Amomun kravanh & Zingiberaceae & Mature fruits & [81] \\
\hline & & & & Peilan & Eupatorium fortune & Compositae & Aerial part & [81] \\
\hline & & & & Zhizhuxiang & Valeriana jatamansii & Valerianaceae & Rhizomes & [81] \\
\hline & & & & Zhaowabaidoukou & Amonum compactum & Zingiberaceae & Mature fruits & [81] \\
\hline & & & & Yangshicao & Achillea millefolium & Compositae & Whole grass & [81] \\
\hline 58 & Menthol & $2216-51-5$ & $\mathrm{C}_{10} \mathrm{H}_{20} \mathrm{O}$ & Bohe & Mentha canadaensis & Labiatae & Whole grass or leaves & [81] \\
\hline \multirow[t]{6}{*}{59} & Paeoniflorin & $23180-57-6$ & $\mathrm{C}_{23} \mathrm{H}_{28} \mathrm{O}_{11}$ & Baishao & PaconialactifloraPall & Paeoniaceae & Roots & [81] \\
\hline & & & & Caoshaoyao & Paeonia obovata & Paeoniaceae & Roots & [81] \\
\hline & & & & Meilishaoyao & Paeonia mairei & Paeoniaceae & Roots & [81] \\
\hline & & & & Zhaiyeshaoyao & Paeonia anomala & Paeoniaceae & Roots & [81] \\
\hline & & & & Kuaigenshaoyao & Paeonia anomala & Paeoniaceae & Roots & [81] \\
\hline & & & & Mudanpi & Paeonia suffruticosa & Paeoniaceae & Root barks & [81] \\
\hline \multirow[t]{9}{*}{60} & Borneol & $507-70-0$ & $\mathrm{C}_{10} \mathrm{H}_{8} \mathrm{O}$ & Ainaxiang & Blumea balsamifera & Compositae & Whole grass & [81] \\
\hline & & & & Zhaowabaidoukou & Amonum compactum & Zingiberaceae & Mature fruits & [81] \\
\hline & & & & Gangsong & Baeckea frutescens & Myrtaceae & Branch leaves & [81] \\
\hline & & & & Juhua & Dendranthema morifolium & Compositae & Capitulum & [81] \\
\hline & & & & Midiexiang & Rosmarinus officinalis & Labiatae & Whole grass & [81] \\
\hline & & & & Yangchunsharen & Amomum villosum & Zingiberaceae & Seeds & [91] \\
\hline & & & & Lvkesharen & Amomum villosum & Zingiberaceae & Seeds & [91] \\
\hline & & & & Shabnai & Kaempferia galangal & Zingiberaceae & Rhizomes & [91] \\
\hline & & & & Shengjiang & Zingiber officinale & Zingiberaceae & Freshrhizomes & [91] \\
\hline 61 & Swertiamarin & $17388-39-5$ & $\mathrm{C}_{16} \mathrm{H}_{22} \mathrm{O}_{10}$ & Longdan & Gentiana scabra & Gentianaceae & Roots and Rhizomes & [81] \\
\hline 62 & Geniposide & $24512-63-8$ & $\mathrm{C}_{17} \mathrm{H}_{24} \mathrm{O}_{10}$ & Duzhong & Eucommia ulmoides & Eucommiaceae & Barks & [91] \\
\hline
\end{tabular}


J Pharm Pharm Sci (www.cspsCanada.org) 21, 437 - 480, 2018

\begin{tabular}{|c|c|c|c|c|c|c|c|c|}
\hline & & & & Zhizi & Gardenia jasminoides & Rubiaceae & Fruits & {$[91]$} \\
\hline \multirow[t]{4}{*}{63} & Geraniol & $106-24-1$ & $\mathrm{C}_{10} \mathrm{H}_{18} \mathrm{O}$ & Lushaxiangmao & Cymbopogon martini & Gramineae & Leaves & [119] \\
\hline & & & & Yaxiangmao & Cymbopogon nardus & Gramineae & Leaves & [119] \\
\hline & & & & Fengmao & Cymbopogon winterianus & Gramineae & Stems and leaves & [119] \\
\hline & & & & Xiangyetianzhukui & Pelargonium graveolens & Geraniaceae & Leaves & {$[119]$} \\
\hline 64 & [6]-Gingerol & $23513-14-6$ & $\mathrm{C}_{17} \mathrm{H}_{26} \mathrm{O}_{4}$ & Shengjiang & Zingiber officinale & Zingiberaceae & Freshrhizomes & {$[=120]$} \\
\hline 65 & Myrtenol & & & Juhao & Tanacetum vulgare & Compositae & Aerial part & {$[-78]$} \\
\hline \multicolumn{9}{|c|}{ Aromatic compounds } \\
\hline \multirow[t]{3}{*}{66} & Paeonol & $552-41-0$ & $\mathrm{C}_{9} \mathrm{H}_{10} \mathrm{O}_{3}$ & Baishao & PaconialactifloraPall & Paeoniaceae & Roots & {$[81]$} \\
\hline & & & & Mudanpi & Aeonia suffruticosa & Paeoniaceae & Root barks & {$[81]$} \\
\hline & & & & Xuzchangqing & Paniculate Swallowwort & Asclepiadaceae & Roots & {$[81]$} \\
\hline 67 & Divaricatol & & $\mathrm{C}_{17} \mathrm{H}_{18} \mathrm{O}_{7}$ & Fangfeng & Saposhnikouia diuaricata & Umbelliferae & Roots & {$[81]$} \\
\hline \multirow[t]{4}{*}{68} & Cinnamaldehyde & $104-55-2$ & $\mathrm{C}_{9} \mathrm{H}_{8} \mathrm{O}$ & Guipi & Cinnamomum japonicum & Lauraceae & Barks & {$[81]$} \\
\hline & & & & Guizhi & Cinnamomum cassia Presl & Lauraceae & Shoots & {$[81]$} \\
\hline & & & & Моyаo & Commiphora myrrha & Burseraceae & Resin & {$[81]$} \\
\hline & & & & Rougui & Cinnamomum cassia & Lauraceae & Barks & {$[81]$} \\
\hline 69 & Sinapyl alcohol & $537-33-7$ & $\mathrm{C}_{11} \mathrm{H}_{14} \mathrm{O}_{4}$ & Tiannvmulan & Magnolia sieboldii & Magnoliaceae & Stem barks & {$[121]$} \\
\hline \multirow[t]{11}{*}{70} & Caffeic acid & $501-16-6$ & $\mathrm{C}_{9} \mathrm{H}_{8} \mathrm{O}_{4}$ & Bianxu & Polygonum aviculare & Polygonaceae & Whole grass & {$[81]$} \\
\hline & & & & Bohe & Mentha canadaensis & Labiatae & Whole grass or leaves & {$[81]$} \\
\hline & & & & Chuanxiong & Ligusticum chuanxiong & Umbelliferae & Rhizomes & {$[81]$} \\
\hline & & & & Danshen & Slauia miltiorrhiza & Labiatae & Roots & {$[81]$} \\
\hline & & & & Huanghemaorendong & Lonicera fuluotomentosa & Caprifoliaceae & Flower bud & {$[81]$} \\
\hline & & & & Mutianliao & Actinidia polygama & Actinidiaceae & Branch leaves & {$[81]$} \\
\hline & & & & Ningmeng & Citrus limonia & Rutaceae & Fruits & {$[81]$} \\
\hline & & & & Pugongying & Taraxacum mongolicum & Compositae & Whole grass & [81] \\
\hline & & & & Yinchenhao & Artemisia capillaris & Compositae & Seedling & {$[81]$} \\
\hline & & & & Zhizhuxiang & Valeriana jatamansii & Valerianaceae & Rhizomes & {$[81]$} \\
\hline & & & & Xiakucao & Prunella vulgaris & Labiatae & Ear & {$[85]$} \\
\hline
\end{tabular}


J Pharm Pharm Sci (www.cspsCanada.org) 21, 437 - 480, 2018

\begin{tabular}{|c|c|c|c|c|c|c|c|c|}
\hline & & & & Yinchimihoutao & Actinidia callosa & Actinidiaceae & Fruits & [122] \\
\hline \multicolumn{9}{|c|}{ Coumarins } \\
\hline \multirow[t]{2}{*}{71} & Notopterol & $88206-46-6$ & $\mathrm{C}_{21} \mathrm{H}_{22} \mathrm{O}_{5}$ & Qianghuo & Notopterygium incisum & Umbelliferae & Roots and rhizomes & [81] \\
\hline & & & & Kuanyeqianghuo & Notopterygium forbesii & Umbelliferae & Roots and rhizomes & [81] \\
\hline \multirow[t]{2}{*}{72} & Columbianadin & $5058-13-9$ & $\mathrm{C}_{19} \mathrm{H}_{20} \mathrm{O}_{5}$ & Duhuo & Angelica biserrata & Umbelliferae & Roots & [123] \\
\hline & & & & Shechuangzi & Cnidium monnieri & Umbelliferae & Fruits & [123] \\
\hline \multirow[t]{3}{*}{73} & Daphnetin & $486-35-1$ & $\mathrm{C}_{9} \mathrm{H}_{6} \mathrm{O}_{4}$ & Ruixianghua & Daphne odora & Thymelaeaceae & Flowers & {$[81]$} \\
\hline & & & & Ruixianggen & Daphne odora & Thymelaeaceae & Roots or root barks & [81] \\
\hline & & & & Jinbianruixiang & Daphne odora & Thymelaeaceae & Whole plant & [124] \\
\hline 74 & Decursinol & $23458-02-8$ & $\mathrm{C}_{14} \mathrm{H}_{14} \mathrm{O}_{4}$ & Chaoxiandanggui & Angelica gigas Nakai & Umbelliferae & Roots & [125] \\
\hline \multirow[t]{2}{*}{75} & $7-$ & $93-35-6$ & $\mathrm{C}_{9} \mathrm{H}_{6} \mathrm{O}_{3}$ & Jiulixiang & Murraya exotica & Rutaceae & Stems and leaves & [126] \\
\hline & Hydroxycoumarin & & & & & & & \\
\hline \multirow[t]{3}{*}{76} & Osthole & $484-12-8$ & $\mathrm{C}_{15} \mathrm{H}_{16} \mathrm{O}_{3}$ & Shechuangzi & Cnidium monnieri & Umbelliferae & Fruits & {$[50]$} \\
\hline & & & & Duhuo & Angelicae pubescentis & Umbelliferae & Roots & [127] \\
\hline & & & & Changchunqi & Libanotis buchtormensis & Umbelliferae & Roots & {$[81]$} \\
\hline \multirow[t]{2}{*}{77} & Albiflorin & $39011-90-0$ & $\mathrm{C}_{23} \mathrm{H}_{28} \mathrm{O}_{11}$ & Baishao & PaconialactifloraPall & Paeoniaceae & Roots & {$[77]$} \\
\hline & & & & Chishao & Paeonia veitchii Lynch & Paeoniaceae & Roots & {$[77]$} \\
\hline 78 & Scopoletin & $92-61-5$ & $\mathrm{C}_{10} \mathrm{H}_{8} \mathrm{O}_{4}$ & Yuanzhuihuayuanzhi & Polygala paniculata & Polygalaceae & Whole grass & [128] \\
\hline \multicolumn{9}{|c|}{ Aliphaticnaturalproducts } \\
\hline 79 & Fumaric acid & $110-17-8$ & $\mathrm{C}_{4} \mathrm{H}_{4} \mathrm{O}_{4}$ & Yanhusuo & Corydalis yanhusuo & Papaveraceae & Tubers & [91] \\
\hline \multirow[t]{3}{*}{80} & Embelin & $550-24-3$ & $\mathrm{C}_{17} \mathrm{H}_{26} \mathrm{O}_{4}$ & Maguihua & Embelia oblongifolia & Myrsinaceae & Fruits & {$[91]$} \\
\hline & & & & Zhushagen & Ardisia crenata & Myrsinaceae & Roots & {$[91]$} \\
\hline & & & & Baihuasuantengguo & Embelia ribes & Myrsinaceae & Fruits & [129] \\
\hline \multicolumn{9}{|c|}{ Lignans } \\
\hline \multirow[t]{3}{*}{81} & Liriodendrin & $573-44-4$ & $\mathrm{C}_{34} \mathrm{H}_{46} \mathrm{O}_{18}$ & Ciwujia & Acanthopanax senticosus & Araliaceae & $\begin{array}{l}\text { Roots/rhizomes/stems/ } \\
\text { leaves }\end{array}$ & {$[81]$} \\
\hline & & & & Duzhong & Eucommia ulmoides & Eucommiaceae & Bark & {$[81]$} \\
\hline & & & & Liuchuanyu & Linaria vulgaris & Scrophulariaceae & Whole grass & {$[81]$} \\
\hline
\end{tabular}


J Pharm Pharm Sci (www.cspsCanada.org) 21, 437 - 480, 2018

Note:

1: The plants which the compound was isolated from;

2: The Latin name of the corresponding plant;

3: The medical part of the corresponding plant; 
J Pharm Pharm Sci (www.cspsCanada.org) 21, 437 - 480, 2018

Table 2 Experimental studies with positive results carried out on analgesic compounds in vivo

\begin{tabular}{|c|c|c|c|c|}
\hline No. & Name & Doses & Analgesic effect & Ref \\
\hline \multicolumn{5}{|c|}{ Alkaloids } \\
\hline \multirow[t]{3}{*}{1} & Trilobine & $5 / 10 / 20 / 40 \mathrm{mg} / \mathrm{kg}$ i.p & Hot-plate test in mice & [130] \\
\hline & & $5 / 10 / 20 / 40 \mathrm{mg} / \mathrm{kg}$ i.p & Acetic acid writhing test in mice & [130] \\
\hline & & $50 / 75 / 100 \mathrm{mg} / \mathrm{kg}$ i.p & Radiant heat tail flick test in rats & {$[130]$} \\
\hline \multirow[t]{2}{*}{2} & Palmatine & $20 / 100 / 200 \mathrm{mg} / \mathrm{kg}$ p.o & $p$-Benzoquinone-induced abdominal constriction test in mice & [131] \\
\hline & & $14 / 56 \mathrm{mg} / \mathrm{kg}$ i.p & Acetic acid-induced writhing in rats & [93] \\
\hline 3 & Tetrandrine & $45 \mathrm{mg} / \mathrm{kg}$ i.p & Induction of hyperalgesia by LPS in BALB/C mice & {$[132]$} \\
\hline \multirow[t]{2}{*}{4} & Berberine & $200 \mathrm{mg} / \mathrm{kg}$ p.o & $p$-Benzoquinone-induced abdominal constriction test in mice & [131] \\
\hline & & $50 \mathrm{mg} / \mathrm{kg}$ p.o & Visceral hypersensitivity in inducted colitis rats & [71] \\
\hline \multirow[t]{4}{*}{5} & Rhoifoline A & $20-80 \mathrm{mg} / \mathrm{kg}$ i.p. & Acetic acid-induced writhing in mice & [41] \\
\hline & & $10-80 \mathrm{mg} / \mathrm{kg}$ i.p. & Formalin test in mice & [41] \\
\hline & & $20-80 \mathrm{mg} / \mathrm{kg}$ i.p. & Tail-flick test in mice & {$[41]$} \\
\hline & & $10-80 \mathrm{mg} / \mathrm{kg}$ i.p. & Hot-plate test in mice & {$[41]$} \\
\hline \multirow[t]{5}{*}{6} & Dicentrine & $0.15 \mathrm{~g} /$ rat i.c.v & Electrical stimulation in rats & {$[95]$} \\
\hline & & $100 \mathrm{mg} / \mathrm{kg}$ p.o & Mechanical hypersensitivity in CFA-induced inflammatory pain in mice & {$[59]$} \\
\hline & & $100 \mathrm{mg} / \mathrm{kg}$ p.o & Thermal hypersensitivity in CFA-induced inflammatory pain in mice & [59] \\
\hline & & $100 \mathrm{mg} / \mathrm{kg}$ p.o & Cold-Hot plate test in capsaicin-induced pain in mice & [59] \\
\hline & & $100 \mathrm{mg} / \mathrm{kg}$ p.o & Cold-Hot plate test in cinnamaldehyde-induced pain in mice & [59] \\
\hline \multirow[t]{2}{*}{7} & Govaniadine & $1.25-5.0 \mathrm{mg} / \mathrm{kg}$ i.p & Acetic acid induced writhing in mice & {$[19]$} \\
\hline & & $2.5 / 5 \mathrm{mg} / \mathrm{kg}$ i.p. & Hot-plate test in mice & {$[19]$} \\
\hline \multirow[t]{4}{*}{8} & Sinomenine & $10-40 \mathrm{mg} / \mathrm{kg}$ & Von Frey test in CCI rats & {$[133]$} \\
\hline & & $10-80 \mathrm{mg} / \mathrm{kg} \mathrm{po} / \mathrm{i} . \mathrm{p}$ & Von Frey test in postoperative pain model in rats & {$[133]$} \\
\hline & & $80 \mathrm{mg} / \mathrm{kg}$ p.o & Von Frey test in carrageenan induced inflammation pain in mice & {$[37]$} \\
\hline & & $80 \mathrm{mg} / \mathrm{kg}$ p.o & Heat hyperalgesia test in carrageenan induced inflammation pain in mice & [134] \\
\hline
\end{tabular}


J Pharm Pharm Sci (www.cspsCanada.org) 21, 437 - 480, 2018

\begin{tabular}{|c|c|c|c|c|}
\hline & & $40 / 80 \mathrm{mg} / \mathrm{kg}$ i.p & Von Frey test in photochemically induced SNI in mice and rats & {$[135]$} \\
\hline & & $40 / 80 \mathrm{mg} / \mathrm{kg}$ i.p & Von Frey test in photochemically-induced spinal cord injury in rats & [43] \\
\hline & & $40 \mathrm{mg} / \mathrm{kg}$ i.p & Hot plate test in rats & [43] \\
\hline & & $40 \mathrm{mg} / \mathrm{kg}$ i.p & Tail flick test in rats & [43] \\
\hline & & $50 \mathrm{mg} / \mathrm{kg}$ i.p & Formalin test & [43] \\
\hline \multirow[t]{10}{*}{9} & Tetrahydropalmatine & $40 / 60 \mathrm{mg} / \mathrm{kg}$ i.g & Thermal hyperalgesia test in bone cancer pain model in rats & [65] \\
\hline & & $40 / 60 \mathrm{mg} / \mathrm{kg}$ i.g & Mechanical allodynia test in bone cancer pain model in rats & [65] \\
\hline & & 20/200 nmol i.p & Formalin test in mice & {$[136]$} \\
\hline & & 20 nmol i.p & Mechanical allodynia test in CCI mice & {$[136]$} \\
\hline & & $2 \mathrm{nmol}$ i.t & Mechanical allodynia test in CCI mice & {$[136]$} \\
\hline & & 20 nmol i.p & Mechanical allodynia test in CCI mice & {$[136]$} \\
\hline & & $2 \mathrm{nmol}$ i.t & Mechanical allodynia test in CCI mice & {$[136]$} \\
\hline & & $1-4 \mathrm{mg} / \mathrm{kg}$ i.p. & Mechanical hyperalgesia test in inflammatory pain model & [32] \\
\hline & & $1-4 \mathrm{mg} / \mathrm{kg}$ i.p. & Mechanical hyperalgesia test in neuropathic pain model & [32] \\
\hline & & $60 \mathrm{mg} / \mathrm{kg}$ i.g & Acetic acid-induced writhing in rats & {$[137]$} \\
\hline \multirow[t]{10}{*}{10} & Gelsemine & $\mathrm{ED}_{50}=21.1 \mu \mathrm{g}$ & Formalin test in rats & {$[138]$} \\
\hline & & $\mathrm{ED}_{50}=0.5 \mu \mathrm{g}$ & Mechanical allodynia in bone cancer rats & [52] \\
\hline & & $\mathrm{ED}_{50}=0.5 \mu \mathrm{g}$ & Mechanical allodynia in PSNL rats & [52] \\
\hline & & $\mathrm{ED}_{50}=5.85 \mathrm{mg} / \mathrm{kg} \mathrm{s.c}$ & Acetic acid induced writhing in mice & {$[139]$} \\
\hline & & $2.0 \mathrm{mg} / \mathrm{kg} \mathrm{s.c}$ & Formalin test in rats & {$[139]$} \\
\hline & & $0.8 \mathrm{mg} / \mathrm{kg}$ p.o & Thermal threshold test in CFA-induced inflammation pain model & {$[139]$} \\
\hline & & $0.28 \mathrm{mg} / \mathrm{kg}$, twice $/$ day for 7 days s.c & Thermal/Mechanical test in CCI rats & {$[139]$} \\
\hline & & $0.28 \mathrm{mg} / \mathrm{kg}$, twice $/$ day for 7 days s.c & Thermal/Mechanical test in L5 SNL ratsThermal/Mechanical test in rat model of & {$[139]$} \\
\hline & & $8 / 200 \mu \mathrm{g}$ i.t & postoperative painMechanical allodynia in diabetic neuropathic pain in rat & [76] \\
\hline & & $0.056-7 \mathrm{mg} / \mathrm{kg} \mathrm{s.c}$ & & {$[140]$} \\
\hline 11 & Coronaridine & $10 \mathrm{mg} / \mathrm{kg}$ i.p & Acetic acid-induced writhing in mice & {$[141]$} \\
\hline 12 & Rutaecarpine & $100 \mathrm{mg} / \mathrm{kg}$ & Acetic acid-induced writhing in mice & {$[142]$} \\
\hline 13 & Mitragynine & $35 \mathrm{mg} / \mathrm{kg}$ i.p & Hot-plate test in mice & [98] \\
\hline
\end{tabular}


J Pharm Pharm Sci (www.cspsCanada.org) 21, 437 - 480, 2018

\begin{tabular}{|c|c|c|c|c|}
\hline \multirow[t]{2}{*}{14} & Harmine & $10 / 15 \mathrm{mg} / \mathrm{kg}$ i.p & Hot-plate test in mice & [99] \\
\hline & & 2.5/5/10 i.p & Formalin test in rats & [99] \\
\hline 15 & $\begin{array}{l}(3 S, 4 S, 15 S, 20 R) \text { - antirhine } N_{4^{-}} \\
\text {oxide }\end{array}$ & $20 \mathrm{mg} / \mathrm{kg}$ i.p & Hot-plate test in mice & {$[100]$} \\
\hline 16 & 21- $O$-syringoylantirhine & $20 \mathrm{mg} / \mathrm{kg}$ i.p & Hot-plate test in mice & {$[100]$} \\
\hline 17 & Alangine & $20 \mathrm{mg} / \mathrm{kg}$ i.p & Hot-plate test in mice & {$[100]$} \\
\hline 18 & Antirhine & $20 \mathrm{mg} / \mathrm{kg}$ i.p & Hot-plate test in mice & {$[100]$} \\
\hline \multirow[t]{2}{*}{19} & Harmane & $5-20 \mathrm{mg} / \mathrm{kg}$ i.p & Hot-plate test in mice & [99] \\
\hline & & 2.5/5/10 i.p & Formalin test in rats & [99] \\
\hline \multirow[t]{2}{*}{20} & Norharmane & $5-15 \mathrm{mg} / \mathrm{kg}$ i.p & Hot-plate test in mice & [99] \\
\hline & & $2.5 / 5 / 10 \mathrm{mg} / \mathrm{kg}$ i.p & Formalin test in rats & [99] \\
\hline \multirow[t]{7}{*}{21} & Mesaconitine & $2 \mathrm{mg} / \mathrm{kg}$ p.o & Acetic acid-induced writhing in mice & {$[143]$} \\
\hline & & $\begin{array}{l}5 \mu \mathrm{g} / \mathrm{rat} \text { injected into the NRPG/ } \\
\mathrm{NRM} / \mathrm{PAG}\end{array}$ & Paw pressure test in rats & {$[144]$} \\
\hline & & $0.5 \mathrm{mg} / \mathrm{kg} \mathrm{p.o}$ & Randall-Selitto method in adjuvant arthritis rats & {$[145]$} \\
\hline & & $0.5 \mathrm{mg} / \mathrm{kg} \mathrm{p.o}$ & The repeated cold stress in rats & {$[145]$} \\
\hline & & $60 \mu \mathrm{g} / \mathrm{kg}$ p.o & Tail-flick test in mice & {$[145]$} \\
\hline & & $0.025 \mathrm{mg} / \mathrm{kg}$ i.p & Acetylcholine cramp model & {$[146]$} \\
\hline & & $0.025 \mathrm{mg} / \mathrm{kg}$ i.p & Inflammatory hyperalgesia in outbred rats & {$[146]$} \\
\hline \multirow[t]{3}{*}{22} & Yunaconitine & $100 \mu \mathrm{g} / \mathrm{kg} \mathrm{s.c}$ & Hot-plate test in mice & {$[147]$} \\
\hline & & $30 \mu \mathrm{g} / \mathrm{kg} \mathrm{s.c}$ & Formalin test in rats & {$[147]$} \\
\hline & & $0.4 \mathrm{mg} / \mathrm{kg}$ p.o & Acetic acid-induced writhing in mice & {$[102]$} \\
\hline \multirow[t]{6}{*}{23} & Lappaconitine & $2.5 / 2.6 / 3.0 \mathrm{mg} / \mathrm{kg}$ iv & Formalin test in NMRI mice & {$[148]$} \\
\hline & & $1,127 \mu \mathrm{g} /$ mouse i.t. & Tail pinch test in mice & [149] \\
\hline & & $2,333 \mu \mathrm{g} /$ mouse icv & Tail pinch test in mice & [149] \\
\hline & & $2,413 \mu \mathrm{g} /$ mouse i.cist & Tail pinch test in mice & {$[149]$} \\
\hline & & $644 \mu \mathrm{g} / \mathrm{mouse}$ i.t. & Hot plate test in mice & [149] \\
\hline & & $607 \mu \mathrm{g} / \mathrm{mouse} \mathrm{icv}$ & Hot plate test in mice & [149] \\
\hline
\end{tabular}


J Pharm Pharm Sci (www.cspsCanada.org) 21, 437 - 480, 2018

\begin{tabular}{|c|c|c|c|c|}
\hline & & $532 \mu \mathrm{g} /$ mouse i.cist & Hot plate test in mice & [149] \\
\hline & & $62.5 \mu \mathrm{g} /$ mouse i.t. & Acetic acid-induced writhing test & [149] \\
\hline & & $308 \mu \mathrm{g} /$ mouse icv & Acetic acid-induced writhing test & [149] \\
\hline & & $233 \mu \mathrm{g} /$ mouse i.cist & Acetic acid-induced writhing test & [149] \\
\hline \multirow[t]{9}{*}{24} & Bullatine A & $3 \mathrm{mg} / \mathrm{kg} \mathrm{s.c}$ & Mechanical allodynia test in neuropathic model in rats & {$[24]$} \\
\hline & & $3 \mathrm{mg} / \mathrm{kg} \mathrm{s.c}$ & Heat hyperalgesia test in neuropathic model in rats & {$[24]$} \\
\hline & & $3 \mathrm{mg} / \mathrm{kg}$ s.c & Mechanical allodynia test in diabetic neuropathic pain in rats & {$[24]$} \\
\hline & & $3 \mathrm{mg} / \mathrm{kg}$ s.c & Heat hyperalgesia test in diabetic neuropathic pain in rats & {$[24]$} \\
\hline & & $3 \mathrm{mg} / \mathrm{kg}$ s.c & Mechanical allodynia test in inflammatory pain model in rats & {$[24]$} \\
\hline & & $3 \mathrm{mg} / \mathrm{kg}$ s.c & Heat hyperalgesia test in inflammatory pain model in rats & {$[24]$} \\
\hline & & $3 \mathrm{mg} / \mathrm{kg}$ s.c & Mechanical allodynia test in bone cancer pain model in rats & {$[24]$} \\
\hline & & $3 \mathrm{mg} / \mathrm{kg}$ s.c & Heat hyperalgesia test in bone cancer pain model in rats & {$[24]$} \\
\hline & & $\mathrm{ED}_{50}: 0.9 \mathrm{mg} / \mathrm{kg} \mathrm{s.c}$ & Formalin test in mice & {$[150]$} \\
\hline 25 & Aconitine & $0.1 \mathrm{mg} / \mathrm{kg} \mathrm{p.o}$ & Acetic acid-induced writhing in wild-type and $\mathrm{Mdr} 1 \mathrm{a}^{-/-} \mathrm{FVB}$ mice & {$[151]$} \\
\hline 26 & Guiwuline & $\mathrm{ED}_{50}=15 \mathrm{mg} / \mathrm{kg}$ i.g & Hot-plate test & {$[103]$} \\
\hline \multirow[t]{5}{*}{27} & Incarvillateine & $10 / 20 \mathrm{mg} / \mathrm{kg}$ i.p & Acetic acid writhing test & {$[64]$} \\
\hline & & $10 / 20 \mathrm{mg} / \mathrm{kg}$ i.p & Mechanical/thermal sensitivity measurement in SNI mice & {$[64]$} \\
\hline & & $10 / 20 \mathrm{mg} / \mathrm{kg}$ i.p & Von Frey test in CFA-induced inflammation pain in mice & {$[64]$} \\
\hline & & $10 / 20 \mathrm{mg} / \mathrm{kg}$ i.p & Mechanical sensitivity test in paclitaxel-induced neuropathic pain model & {$[64]$} \\
\hline & & $10 / 20 \mathrm{mg} / \mathrm{kg}$ i.p & Thermal sensitivity test in paclitaxel-induced neuropathic pain model & {$[64]$} \\
\hline 28 & 8-O-ethylaconosine & 50/100/200 mg p.o & Acetic acid induced writhing in mice & [104] \\
\hline 29 & Aconicarmisulfonine A & $1.0 / 0.3 / 0.1 \mathrm{mg} / \mathrm{kg}$ i.p & Acetic acid induced writhing in mice & [105] \\
\hline \multirow[t]{6}{*}{30} & Oxymatrine & $80 \mathrm{mg} / \mathrm{kg}$ i.p & Von Frey test in CCI mice & {$[56]$} \\
\hline & & $80 \mathrm{mg} / \mathrm{kg}$ i.p & Thermal hyperalgesia in CCI mice & {$[56]$} \\
\hline & & $8.75-75 \mathrm{mg} / \mathrm{kg}$ i.p & Hot-plate test in mice & {$[56]$} \\
\hline & & $150 \mathrm{mg} / \mathrm{kg}$ ip & Tail immersion test in mice & {$[56]$} \\
\hline & & $18.75-150 \mathrm{mg} / \mathrm{kg}$ ip & Acetic acid-induced writhing in mice & {$[56]$} \\
\hline & & $75-150 \mathrm{mg} / \mathrm{kg}$ & Formalin test in mice & {$[56]$} \\
\hline
\end{tabular}


J Pharm Pharm Sci (www.cspsCanada.org) 21, 437 - 480, 2018

\begin{tabular}{|c|c|c|c|c|}
\hline & & $1.875-7.5 \mathrm{mg} / \mathrm{kg} \mathrm{icv}$ & Tail immersion test in mice & [39] \\
\hline \multirow[t]{3}{*}{31} & $(-)$-Spectaline & $300 \mu \mathrm{mol} / \mathrm{kg}$ p.o & Acetic acid-induced writhing in mice & [106] \\
\hline & & $1-100 \mu \mathrm{mol} / \mathrm{kg}$ p.o & Capsaicin-induced pain in mice & [106] \\
\hline & & $100 \mu \mathrm{mol} / \mathrm{kg}$ p.o & Acetylcholine-induced abdominal constriction in mice & {$[107]$} \\
\hline \multirow[t]{4}{*}{32} & Huperzine A & $110 \mu \mathrm{g} / \mathrm{kg}$ i.p & Hot-plate test in mice & {$[27]$} \\
\hline & & $\mathrm{ED}_{50}=0.57 \mu \mathrm{g}$ i.t & Formalin test in rats & {$[27]$} \\
\hline & & $50-500 \mu \mathrm{g} / \mathrm{kg}$ i.t/i.p & Von Frey assay in static compression model in rats & {$[27]$} \\
\hline & & $0.02 / 0.075 \mathrm{mg} / \mathrm{kg}$ i.p & Mechanical allodynia test in rat's common peroneal nerve model & {$[27]$} \\
\hline \multirow[t]{11}{*}{3} & Matrine & $30 \mathrm{mg} / \mathrm{kg}$ i.p & Von Frey test in CCI mice & {$[152]$} \\
\hline & & $15 / 30 \mathrm{mg} / \mathrm{kg}$ i.p & Cold-plate test CCI mice & [152] \\
\hline & & $15 / 30 \mathrm{mg} / \mathrm{kg}$ i.p & Plantar test in CCI mice & {$[152]$} \\
\hline & & $15 / 30 / 60 \mathrm{mg} / \mathrm{kg}$ i.p & Von Frey test in vincristine induced neuropathic pain model in mice & [153] \\
\hline & & $15 / 30 \mathrm{mg} / \mathrm{kg}$ i.p & Thermal hyperalgesia test in vincristine induced neuropathic pain in mice & {$[153]$} \\
\hline & & $15 / 30 \mathrm{mg} / \mathrm{kg}$ i.p & Cold-plate test in vincristine induced neuropathic pain model in mice & [153] \\
\hline & & $10 / 30 \mathrm{mg} / \mathrm{kg}$ s.c & Tail-flick tests & {$[154]$} \\
\hline & & $10 / 20 \mathrm{mg} / \mathrm{kg} \mathrm{s.c}$ & Acetic acid-induced writhing tests in mice & [154] \\
\hline & & $10 / 20 \mathrm{mg} / \mathrm{kg} \mathrm{s.c}$ & Tail-pressure test in mice & [154] \\
\hline & & $10 / 20 \mathrm{mg} / \mathrm{kg} \mathrm{s.c}$ & Hot-plate test in mice & [154] \\
\hline & & $20 \mathrm{mg} / \mathrm{kg}$ i.c.v & Hot-plate test in mice & [154] \\
\hline \multirow[t]{4}{*}{34} & Capsaicin & $10 \mu \mathrm{g}$ i.p & Hot plate test & {$[155]$} \\
\hline & & $25 / 50 / 100 \mu \mathrm{g}$ Intraplantar injection & Formalin test in mice & [155] \\
\hline & & $50 / 100 \mu \mathrm{g}$ Intraplantar injection & von Frey test in chronic inflammatory pain model & [156] \\
\hline & & $100 \mu \mathrm{g}$ Intraplantar injection & von Frey test in chronic neuropathic pain model & {$[156]$} \\
\hline 35 & Scotanamine B & $40 \mathrm{mg} / \mathrm{kg}$ i.p & Tail-flick test in mice & {$[20]$} \\
\hline \multirow[t]{2}{*}{36} & Skimmianine & $98 \mathrm{mg} / \mathrm{kg}$ p.o & Acetic acid writhing test in mice & [157] \\
\hline & & $20 \mathrm{mg} / \mathrm{kg}$ p.o & Hot-plate test in mice & {$[157]$} \\
\hline 37 & Veratraline A & $0.5 \mathrm{mg} / \mathrm{kg}$ i.p & Acetic acid induced writhing in mice & [108] \\
\hline 38 & Veratraline B & $1.0 \mathrm{mg} / \mathrm{kg}$ i.p & Acetic acid induced writhing in mice & [108] \\
\hline
\end{tabular}


J Pharm Pharm Sci (www.cspsCanada.org) 21, 437 - 480, 2018

\begin{tabular}{|c|c|c|c|c|}
\hline 39 & Veratraline $\mathrm{C}$ & $0.5 \mathrm{mg} / \mathrm{kg}$ i.p & Acetic acid induced writhing in mice & {$[108]$} \\
\hline \multirow[t]{2}{*}{40} & Isomurrayafoline $\mathrm{B}$ & $10 / 20 \mathrm{mg} / \mathrm{kg}$ p.o & Hot-plate test in mice & {$[109]$} \\
\hline & & $10 / 20 \mathrm{mg} / \mathrm{kg}$ p.o & Acetic acid induced writhing in mice & {$[109]$} \\
\hline \multicolumn{5}{|c|}{ Flavonoids } \\
\hline 41 & Gossypin & $12.5-100 \mathrm{mg} / \mathrm{kg}$ i.p & Acetic acid-induced writhing in mice & {$[158]$} \\
\hline 42 & Hyperin & $25-150 \mathrm{mg} / \mathrm{kg}$ i.p & Tail flick test in mice & {$[42]$} \\
\hline \multirow[t]{4}{*}{43} & Chrysin & $2.5 / 10 / 20 \mathrm{mg} / \mathrm{kg}$ ip & Acetic acid-induced writhing in mice & {$[110]$} \\
\hline & & $2.5 / 10 / 20 \mathrm{mg} / \mathrm{kg}$ ip & Formalin test in mice & {$[110]$} \\
\hline & & $25 / 50 / 75 / 100 \mathrm{mg} / \mathrm{kg}$ i.p & Tail immersion test in mice & {$[38]$} \\
\hline & & $31 / 100 / 316 \mathrm{mg} / \mathrm{kg}$ & Hot-plate test in mice & {$[159]$} \\
\hline \multirow[t]{3}{*}{44} & Lycopene & 1/2/ 4 mg/kg p.o. & Tail immersion test in diabetic neuropathic pain in mice & {$[74]$} \\
\hline & & 1/2/ $4 \mathrm{mg} / \mathrm{kg}$ p.o. & Hot-plate test in in diabetic neuropathic pain in mice & {$[74]$} \\
\hline & & $10 \mathrm{nmol} / 5 \mu \mathrm{l}$ i.t & Mechanical hypersensitivity threshold test in PSNL mice & {$[86]$} \\
\hline 45 & Eupatilin & $100 \mathrm{mg} / \mathrm{kg}$ p.o & Von Frey test in osteoporotic rats & [111] \\
\hline \multirow[t]{4}{*}{46} & Acacetin & $10 / 100 \mathrm{mg} / \mathrm{kg}$ i.p & Acetic acid-induced writhing in mice & {$[34]$} \\
\hline & & $10 / 100 \mathrm{mg} / \mathrm{kg}$ i.p & Formalin test in mice & {$[34]$} \\
\hline & & $56.2 \mathrm{mg} / \mathrm{kg}$ i.p & Thermal plantar test in carrageenan-induced pain in mice & {$[34]$} \\
\hline & & $100 / 200 / 1,000 \mu \mathrm{g}$ i.a & PIFIR test in rats & {$[34]$} \\
\hline \multirow[t]{6}{*}{47} & Ellagic acid & $1,000 \mu \mathrm{mol} / \mathrm{kg}$ p.o & Tail-flick test in rats & {$[88]$} \\
\hline & & $33 / 100 / 330 / 660 \mu \mathrm{mol} / \mathrm{kg}$ i.p & Tail-flick test in rats & {$[88]$} \\
\hline & & $0.33 / 1 / 2 \mu \mathrm{mol} /$ rat i.c.v. & Tail-flick test in rats & {$[88]$} \\
\hline & & $1-33 \mu \mathrm{mol} / \mathrm{kg}$ i.p. & Acetic acid-induced writhing test & [89] \\
\hline & & $10 / 30 \mathrm{mg} / \mathrm{kg}$ i.p & Formalin test in rats & {$[160]$} \\
\hline & & $10 \mathrm{mg} / \mathrm{kg}$ p.o & Hot plate test in mice & {$[160]$} \\
\hline \multirow[t]{4}{*}{48} & Quercetin & $25 / 50 / 100 \mathrm{mg} / \mathrm{kg}$ i.p & Tail flick test in mice & {$[161]$} \\
\hline & & $25 / 50 / 100 \mathrm{mg} / \mathrm{kg}$ i.p & Hot plate test in mice & {$[161]$} \\
\hline & & $10 / 30 / 100 \mathrm{mg} / \mathrm{kg}$ i.p & Mechanical hyperalgesia in Ehrlich tumor-induced cancer pain in mice & {$[162]$} \\
\hline & & $10 / 30 / 100 \mathrm{mg} / \mathrm{kg}$ i.p & Thermal hyperalgesia in Ehrlich tumor-induced cancer pain in mice & {$[162]$} \\
\hline
\end{tabular}


J Pharm Pharm Sci (www.cspsCanada.org) 21, 437 - 480, 2018

\begin{tabular}{|c|c|c|c|c|}
\hline & & $30 / 100 \mathrm{mg} / \mathrm{kg}$ i.p & Pain-induced functional impairment model in rats & {$[35]$} \\
\hline & & $100 \mathrm{mg} / \mathrm{kg}$ i.p & Formalin test in rats & {$[35]$} \\
\hline & & $50 / 100 \mathrm{mg} / \mathrm{kg}$ p.o & Tail-immersion test in diabetic neuropathic pain in mice & [163] \\
\hline & & $10 / 30 / 60 \mathrm{mg} / \mathrm{kg}$ i.p & Acetic acid-induced abdominal writhing test & [164] \\
\hline & & $10 / 30 / 60 \mathrm{mg} / \mathrm{kg}$ i.p & Capsaicin-induced pain in mice & [164] \\
\hline & & $10 / 30 / 60 \mathrm{mg} / \mathrm{kg}$ i.p & Glutamate-induced pain in mice & [164] \\
\hline & & $10 / 30 / 100 \mathrm{mg} / \mathrm{kg} \mathrm{s.c}$ & Mechanical hypersensitivity test in zymosan-induced arthritis in mice & {$[165]$} \\
\hline & & $10 / 30 / 100 \mathrm{mg} / \mathrm{kg}$ s.c & Mechanical hypersensitivity threshold test in gout arthritis in mice & [166] \\
\hline & & $30 / 100 \mathrm{mg} / \mathrm{kg}$ i.p & Mechanical hypersensitivity titanium dioxide-induced arthritis in mice & [83] \\
\hline & & $25 / 50 / 100 \mathrm{mg} / \mathrm{kg}$ i.p & $\begin{array}{l}\text { Mechanical hypersensitivity threshold test in mouse model of oxaliplatin-induced } \\
\text { chronic painful peripheral neuropathy }\end{array}$ & {$[72]$} \\
\hline & & $25 / 50 / 100 \mathrm{mg} / \mathrm{kg}$ i.p & $\begin{array}{l}\text { Cold nociceptive threshold test in mouse model of oxaliplatin-induced chronic painful } \\
\text { peripheral neuropathy }\end{array}$ & \\
\hline \multirow[t]{5}{*}{49} & Rutin & $30-1000 \mathrm{mg} / \mathrm{kg}$ i.p & Formalin test in rats & [167] \\
\hline & & $25 / 50 / 100 \mathrm{mg} / \mathrm{kg}$ i.p & $\begin{array}{l}\text { Mechanical hypersensitivity threshold test in mouse model of oxaliplatin-induced } \\
\text { chronic painful peripheral neuropathy }\end{array}$ & {$[72]$} \\
\hline & & $25 / 50 / 100 \mathrm{mg} / \mathrm{kg}$ i.p & Cold nociceptive threshold test in mouse model of oxaliplatin-induced chronic painful & {$[72]$} \\
\hline & & & peripheral neuropathy & [168] \\
\hline & & $10-100 \mathrm{mg} / \mathrm{kg}$ p.o. & Acetic acid-induced writhing test in mice & \\
\hline \multirow[t]{4}{*}{50} & Kaempferol & $16 / 32 / 64 \mathrm{mg} / \mathrm{kg}$ i.p & Von Frey test in alloxan-induced diabetic neuropathic pain in mice & [113] \\
\hline & & $16 / 32 / 64 \mathrm{mg} / \mathrm{kg}$ i.p & Hot plate test in alloxan-induced diabetic neuropathic pain in mice & [113] \\
\hline & & $16 / 32 / 64 \mathrm{mg} / \mathrm{kg}$ i.p & Tail flick test in alloxan-induced diabetic neuropathic pain in mice & [113] \\
\hline & & $50 / 100 \mathrm{mg} / \mathrm{kg}$ p.o & Acetic acid-induced writhing test & {$[169]$} \\
\hline \multirow[t]{4}{*}{51} & Hesperidin methyl chalcone & 3/10/30/100 mg/kg i.p & Acetic acid-induced writhing test in mice & {$[62]$} \\
\hline & & $30 \mathrm{mg} / \mathrm{kg}$ i.p & Formalin/Carrageenan/CFA-induced pain in mice & {$[62]$} \\
\hline & & 3/10/30/100 mg/kg i.p & $\begin{array}{l}\text { Mechanical/Thermal hypersensitivity in carrageenan-induced inflammatory pain model } \\
\text { in mice }\end{array}$ & {$[62]$} \\
\hline & & $30 \mathrm{mg} / \mathrm{kg}$ i.p & Mechanical/Thermal hypersensitivity in CFA-induced inflammatory pain in mice & {$[62]$} \\
\hline
\end{tabular}


$30 \mathrm{mg} / \mathrm{kg}$ i.p

$52 \quad$ Hesperidin

Curcumin

$54 \quad$ Kempferol-

3,4'-di- $O$ - $\alpha$-L-rhamn

opyranoside

55 Myricitrin
$100-1,778.3 \mathrm{mg} / \mathrm{kg}$ i.p.

$10 / 30 / 100 \mathrm{mg} / \mathrm{kg}$ i.p.

$10 / 100 /, 1000 \mathrm{mg} / \mathrm{kg}$ i.p.

$0.1 / 0.3 / 0.6 / 1 \mathrm{mg} / \mathrm{kg}$ i.p.

$1 / 10 / 30 \mathrm{mg} / \mathrm{kg}$ i.p.

$50 \mathrm{mg} / \mathrm{kg}$ i.p.

$50 \mathrm{mg} / \mathrm{kg}$ i.p.

$400 \mathrm{mg} / \mathrm{kg}$ p.o.

$400 \mathrm{mg} / \mathrm{kg}$ p.o.

$50 \mathrm{mg} / \mathrm{kg}$ i.p.

$50 \mathrm{mg} / \mathrm{kg}$ i.p.

$50 \mathrm{mg} / \mathrm{kg}$ i.p.

25-600 mg/kg i.p.

$2.5 / 5 / 10 \mathrm{mg} / \mathrm{kg}$ i.p

2.5/5/10 mg/kg i.p.

$30-100 \mathrm{mg} / \mathrm{kg}$ i.p

$30-100 \mathrm{mg} / \mathrm{kg}$ i.p

$30-100 \mathrm{mg} / \mathrm{kg}$ i.p

$30-100 \mathrm{mg} / \mathrm{kg}$ i.p

$0.01-10 \mathrm{mg} / \mathrm{kg}$ i.p

$1-100 \mathrm{mg} / \mathrm{kg}$ p.o

$1-100 \mathrm{mg} / \mathrm{kg}$ i.p

$1-100 \mathrm{mg} / \mathrm{kg}$ i.p

$0.01-10 \mathrm{mg} / \mathrm{kg}$ i.p

$30 \mathrm{mg} / \mathrm{kg}$ i.p
Mechanical/thermal hypersensitivity in capsaicin-induced inflammatory pain model in [62] mice

Pain-induced functional impairment model in rats

Capsaicin-induced pain in mice

Mechanical/thermal hypersensitivity in CCI rats

Acetic acid-induced writhing test in mice

Hot plate test in mice

Thermal hypersensitivity in diabetic neuropathic pain in rats

Mechanical allodynia in diabetic neuropathic pain in rats

Formalin test in rats

Hot plate test in rats

Von Frey test in post-incisional nociceptive sensitization

Hargreaves test in post-incisional nociceptive sensitization

Mechanical allodynia test in spontaneous pain

Nocifensive behavioral scoring in formalin-induced orofacial pain

Acetic acid-induced writhing test in mice

Formalin test in mice

Cold and mechanical allodynia test in menthol induced pain in mice

Cinnamaldehyde-induced pain in mice

Acidified saline-induced pain in mice

Menthol-induced pain in mice

Acetic acid-induced writhing in mice

Acetic acid-induced writhing in mice

Capsaicin-induced pain in mice

Glutamate-induced pain in mice

Phorbol myristate acetate-induced pain in mice

[116]

Mechanical hyperalgesia induced by bradykinin 
J Pharm Pharm Sci (www.cspsCanada.org) 21, 437 - 480, 2018

\begin{tabular}{|c|c|c|c|c|}
\hline & & $30 \mathrm{mg} / \mathrm{kg}$ i.p & Mechanical allodynia induced by PSNL in mice & [176] \\
\hline & & $30 \mathrm{mg} / \mathrm{kg}$ i.p & Mechanical allodynia test in CFA-induced inflammation pain in mice & [176] \\
\hline \multicolumn{5}{|c|}{ Terpenes } \\
\hline \multirow[t]{2}{*}{56} & 1,8-Cineole & 200/400 mg/kg p.o & Formalin test in mice & [177] \\
\hline & & 200/400 mg/kg p.o & Acetic acid-induced writhing in mice & [177] \\
\hline \multirow[t]{4}{*}{57} & $p$-Cymene & $50 / 100 \mathrm{mg} / \mathrm{kg}$ i.p & Acetic acid-induced writhing in mice & [12] \\
\hline & & $25 / 50 / 100 \mathrm{mg} / \mathrm{kg}$ i.p & Formalin-induced pain in mice & [12] \\
\hline & & $50 / 100 \mathrm{mg} / \mathrm{kg}$ i.p & Hot-plate test in mice & [12] \\
\hline & & $25-100 \mathrm{mg} / \mathrm{kg}$ i.p & Tail flick test in mice & [13] \\
\hline \multirow[t]{6}{*}{58} & Menthol & $3-10 \mathrm{mg} / \mathrm{kg}$ p.o & Hot-plate test in mice & [14] \\
\hline & & $3-10 \mathrm{mg} / \mathrm{kg}$ p.o & Acetic acid-induced writhing in mice & [14] \\
\hline & & $10 \mu$ g i.c.v & Tail flick test in mice & [14] \\
\hline & & $10 / 20 \mathrm{mg} / \mathrm{kg}$ i.p & Chemically induced nocifensive behavior & [48] \\
\hline & & 50/100 mg/kg i.p/i.t & Formalin-induced pain in mice & [48] \\
\hline & & $50 / 100 \mathrm{mg} / \mathrm{kg}$ i.p/i.t & Von Frey test of CFA-induced pain in mice & [48] \\
\hline \multirow[t]{7}{*}{59} & Paeoniflorin & $50 \mathrm{mg} / \mathrm{kg}$ i.p & Mechanical withdrawal threshold test in $\mathrm{CCI}$ ats & [77] \\
\hline & & $50 \mathrm{mg} / \mathrm{kg}$ i.p & Thermal withdrawal latency test in CCI rats & [77] \\
\hline & & $10 / 100 / 200 \mu \mathrm{g}$ i.v & Spontaneous pain-related behaviors in rats & [21] \\
\hline & & $10 / 100 / 200 \mu$ g i.v & Thermal pain sensitivity in rats & [21] \\
\hline & & $10 / 100 / 200 \mu \mathrm{g}$ i.v & Mechanical pain sensitivity in rats & [21] \\
\hline & & 30 mg/kg p.o & Tail-pressure test in diabetic neuropathic pain in mice & [31] \\
\hline & & 180 mg/kg i.p & $\begin{array}{l}\text { Abdominal withdraw reflexin test in rats with neonatal maternal separation-induced } \\
\text { visceral hyperalgesia }\end{array}$ & {$[57]$} \\
\hline \multirow[t]{2}{*}{60} & Borneol & $5 / 25 / 50 \mathrm{mg} / \mathrm{kg}$ ip & Acetic acid-induced writhing in mice & [178] \\
\hline & & $5 / 25 / 50 \mathrm{mg} / \mathrm{kg}$ ip & Formalin-induced pain in mice & [178] \\
\hline \multirow[t]{3}{*}{61} & Swertiamarin & $100 / 200 \mathrm{mg} / \mathrm{kg}$ po & Tail immersion test in mice & [179] \\
\hline & & $100 / 200 \mathrm{mg} / \mathrm{kg}$ po & Acetic acid-induced writhing in mice & [179] \\
\hline & & $100 / 200 \mathrm{mg} / \mathrm{kg}$ ро & Hot-plate test in mice & [179] \\
\hline
\end{tabular}


J Pharm Pharm Sci (www.cspsCanada.org) 21, 437 - 480, 2018

\begin{tabular}{|c|c|c|c|c|}
\hline 62 & Geniposide & $\mathrm{ED}_{50}=17.3 \mu \mathrm{g}$ ith & Formalin-induced pain in rats & {$[84]$} \\
\hline \multirow[t]{4}{*}{63} & Geraniol & $12.5 / 25 / 50 \mathrm{mg} / \mathrm{kg}$ i.p/p.o & Acetic acid-induced writhing in mice & [119] \\
\hline & & $25 \mathrm{mg} / \mathrm{kg}$ i.p. & Acetic acid-induced writhing test in mice & [119] \\
\hline & & $12.5 / 25 / 50 \mathrm{mg} / \mathrm{kg}$ i.p & Formalin-induced pain in mice & [119] \\
\hline & & $12.5 / 25 / 50 \mathrm{mg} / \mathrm{kg}$ i.p & Glutamate test in mice & [119] \\
\hline \multirow[t]{2}{*}{64} & [6]-Gingerol & $12.5 / 25 / 50 \mathrm{mg} / \mathrm{kg}$ i.p & Acetic acid-induced writhing in mice & {$[120]$} \\
\hline & & $25 / 50 \mathrm{mg} / \mathrm{kg}$ i.p & Formalin test in mice & {$[120]$} \\
\hline \multirow[t]{5}{*}{65} & Myrtenol & 75 mg/kg i.p. & Acetic acid-induced writhing in mice & {$[78]$} \\
\hline & & 75 mg/kg i.p. & Formalin test in mice & {$[78]$} \\
\hline & & 75 mg/kg i.p. & Hot-plate test in mice & {$[78]$} \\
\hline & & $75 \mathrm{mg} / \mathrm{kg}$ i.p. & Glutamate test in mice & {$[78]$} \\
\hline & & $75 \mathrm{mg} / \mathrm{kg}$ i.p. & Capsaicin test in mice & {$[78]$} \\
\hline \multicolumn{5}{|c|}{ Aromatic compounds } \\
\hline \multirow[t]{5}{*}{66} & Paeonol & $10 / 50 / 100 \mathrm{mg} / \mathrm{kg}$ p.o & Acetic acid-induced writhing in mice & [180] \\
\hline & & $100 \mathrm{mg} / \mathrm{kg}$ p.o & Formalin-induced pain in mice & {$[180]$} \\
\hline & & $30 / 50 / 100 \mathrm{mg} / \mathrm{kg}$ ip & Thermal threshold test in carrageenan induced inflammatory pain in mice & [181] \\
\hline & & $80 \mathrm{mg} / \mathrm{kg}$ ip & Mechanical hypersensitivity threshold test in CFA-induced pain in mice & {$[55]$} \\
\hline & & $80 \mathrm{mg} / \mathrm{kg}$ ip & Thermal threshold test in in CFA-induced pain & {$[55]$} \\
\hline 67 & Divaricatol & $1 / 5 \mathrm{mg} / \mathrm{kg}$ & Acetic acid-induced writhing in mice & {$[182]$} \\
\hline \multirow[t]{2}{*}{68} & Cinnamaldehyde & $100-400 \mathrm{mg} / \mathrm{kg}$ p.o & Acetic acid-induced writhing in mice & [183] \\
\hline & & $100-400 \mathrm{mg} / \mathrm{kg}$ p.o & Hot-plate test in mice & [183] \\
\hline \multirow[t]{2}{*}{69} & Sinapyl alcohol & $20 / 30 \mathrm{mg} / \mathrm{kg}$ p.o & Acetic acid-induced writhing in mice & [121] \\
\hline & & $20 / 30 \mathrm{mg} / \mathrm{kg}$ p.o & Hot-plate test in mice & [121] \\
\hline \multirow[t]{5}{*}{70} & Caffeic acid & $2.5-100 \mathrm{mg} / \mathrm{kg}$ p.o & Acetic acid-induced writhing in mice & {$[80]$} \\
\hline & & $2.5-100 \mathrm{mg} / \mathrm{kg}$ p.o & Formalin test in mice & {$[80]$} \\
\hline & & $200 \mathrm{mg} / \mathrm{kg}$ p.o & Randall-Selitto test in LPS/carrageenan-induced pain in rats & {$[80]$} \\
\hline & & $2.5-10 \mathrm{mg} / \mathrm{kg}$ i.p & Hot plate latency test in alloxan-induced diabetic neuropathic pain in mice & {$[85]$} \\
\hline & & $2.5-10 \mathrm{mg} / \mathrm{kg}$ i.p & Tail flick latency test in alloxan-induced diabetic neuropathic pain in mice & {$[85]$} \\
\hline
\end{tabular}


J Pharm Pharm Sci (www.cspsCanada.org) 21, 437 - 480, 2018

$2.5-10 \mathrm{mg} / \mathrm{kg}$ i.p $\quad$ Von Frey filaments test in alloxan-induced diabetic neuropathic pain in mice

Coumarins

$71 \quad$ Notopterol

$100 \mathrm{mg} / \mathrm{kg}$ p.o

Acetic acid-induced writhing in mice

Columbianadin

$50 / 100 \mathrm{mg} / \mathrm{kg}$ i.p

$12.5 / 25 / 50 \mathrm{mg} / \mathrm{kg} \mathrm{p.o}$

Formalin test in mice

$12.5 / 25 / 50 \mathrm{mg} / \mathrm{kg}$ p.o

Acetic acid-induced writhing in mice

$12.5 / 25 / 50 \mathrm{mg} / \mathrm{kg} \mathrm{p} . \mathrm{o}$

Hot-plate test in mice

Electric stimulation induced pain in mice

$10-60 \mathrm{mg} / \mathrm{kg}$ p.o

Tail-flick and

$10-60 \mathrm{mg} / \mathrm{kg}$ p.o

Hot-plate tests in mice

$10-100 \mathrm{mg} / \mathrm{kg}$ p.o

Acetic acid-induced writhing in mice

$10-100 \mathrm{mg} / \mathrm{kg}$ p.o

Formalin tests in mice

Von Frey filaments test in CFA induced pain in mice

$30 / 60 / 120 \mathrm{mg} / \mathrm{kg} \mathrm{p.o}$

Acetic acid-induced writhing in mice

3/15/30/60 mg/kg p.o

Formalin tests in rats

$2.5 / 5 / 10 \mathrm{mg} / \mathrm{kg} \mathrm{p.o}$

Hot-plate tests in mice

Von Frey test in nucleus pulposus-evoked pain in rats

$100 \mathrm{mg} / \mathrm{kg}$ i.p

$p$-Benzoquinone-induced writhing in mice

$50 \mu \mathrm{L} \quad 2 \% \quad$ Epidural treatmentED ${ }_{50} \quad$ Von Frey test in nucleus pulposus-induced radicular inflammatory pain in rats

$=5.43 \mathrm{mg} / \mathrm{kg}$

Acetic acid-induced writhing in mice

$\mathrm{ED}_{50}=5.43 \mathrm{mg} / \mathrm{kg}$

$2.5 / 5 / 10 \mathrm{mg} / \mathrm{kg} \mathrm{p.o}$

Hot-plate tests in mice

Tail-pressure test in diabetic neuropathic pain in mice

$1 / 3 / 10 \mathrm{mg} / \mathrm{kg}$ p.o

Mechanical withdrawal threshold testing

$50 \mathrm{mg} / \mathrm{kg}$ i.p

Thermal withdrawal latency testing.

$1 / 5 / 10 \mathrm{mg} / \mathrm{kg}$ i.p

Acetic acid-induced writhing in mice

$1 / 5 / 10 \mathrm{mg} / \mathrm{kg}$ i.p

Formalin tests in mice

[128]

Aliphaticnatural products 
J Pharm Pharm Sci (www.cspsCanada.org) 21, 437 - 480, 2018

\begin{tabular}{|c|c|c|c|c|}
\hline \multirow[t]{3}{*}{79} & Fumaric acid & $2.5 / 5.0 \mathrm{mg} / \mathrm{kg}$ p.o & Acetic acid-induced writhing in mice & [187] \\
\hline & & $1.25 / 2.5 / 5.0 \mathrm{mg} / \mathrm{kg}$ p.o & Hot-plate test in mice & [187] \\
\hline & & $1.25 / 2.5 / 5.0 \mathrm{mg} / \mathrm{kg}$ p.o & Tail flick test in rats & [187] \\
\hline \multirow[t]{3}{*}{80} & Embelin & $10 / 20 \mathrm{mg} / \mathrm{kg}$ i.p & Acetic acid-induced writhing in mice & [129] \\
\hline & & $10 / 20 \mathrm{mg} / \mathrm{kg}$ i.p & Hot-plate test in mice & [129] \\
\hline & & $10 / 20 \mathrm{mg} / \mathrm{kg}$ i.p & Tail immersion test in mice & [129] \\
\hline \multicolumn{5}{|c|}{ Lignans } \\
\hline \multirow[t]{2}{*}{81} & Liriodendrin & $5 / 10 \mathrm{mg} / \mathrm{kg}$ p.o & Acetic acid-induced writhing in mice & [188] \\
\hline & & $5 / 10 \mathrm{mg} / \mathrm{kg}$ p.o & Hot-plate test in mice & [188] \\
\hline
\end{tabular}


J Pharm Pharm Sci (www.cspsCanada.org) 21, 437 - 480, 2018 